*** This paper is now published and can be found and cited as follows: Milks, A., LewLevy, S., Lavi, N., Friesem, D. E., \& Reckin, R. (2021). Hunter-gatherer children in the past: An archaeological review. Journal of Anthropological Archaeology, 64, 101369. https://doi.org/10.1016/j.jaa.2021.101369 **

\title{
Hunter-gatherer children in the past: an archaeological review
}

Authors: Annemieke Milks ${ }^{a,{ }^{*}}$, Sheina Lew-Levy ${ }^{\mathrm{b}, \mathrm{c}}$, Noa Lavi ${ }^{\mathrm{d}}$, David E. Friesem ${ }^{\mathrm{e}, \mathrm{f}}$, Rachel Reckin $^{9}$

a Institute of Archaeology, University College London, 31-34 Gordon Square, London, WC1H OPY, UK, annemieke.milks@gmail.com

${ }^{\mathrm{b}}$ Department of Psychology, Simon Fraser University, 8888 University Drive, Burnaby, B.C. V5A 1S6, Canada, sheinalewlevy@gmail.com

${ }^{c}$ Department of Archaeology and Heritage Studies, Aarhus University, Moesgård Allé 20, Højbjerg, 8270, Denmark, sheinalewlevy@gmail.com

${ }^{\mathrm{d}}$ Department of Anthropology, University College London, 14 Taviton Street, London, WC1H OBW, UK, noalaviw@gmail.com

eThe Recanati Institute of Marine Studies, Department of Maritime Civilizations, School of Marine Sciences, University of Haifa, 199 Aba-Hushi Avenue, Haifa, 3498838, Israel, dfriesem@univ.haifa.ac.il

fThe Haifa Center for Mediterranean History, University of Haifa, 199 Aba-Hushi Avenue, Haifa, 3498838, Israel

9St John's College, University of Cambridge, St John's Street, Cambridge, CB2 1TP, UK, rachel.reckin@gmail.com

\begin{abstract}
Theoretical engagement and methodological innovations geared towards identifying the presence and activities of children in archaeological contexts has increased in pace over the last decade. This paper presents a systematic review of the literature pertaining to the archaeology of hunter-gatherer children ( $H$. sapiens). The review summarises methods and results from 86 archaeological publications, and finds a number of research areas that show material culture relating to hunter-gatherer childhood, including children's playthings and tools, learning to flintknap, and their involvement in the making of marks, art and footprints. The results demonstrate a diversity of evidence from all inhabited continents covering an extensive time frame. Following a thematic synthesis, we further explore the implications of these data for our understanding of the cultural variability and patterning of hunter-gatherer children in the deep past. We discuss possible interpretative pathways that can shed light on children's learning processes, agency, minds and bodies, use of space, and how they were embedded in social worlds. The paper closes by proposing potential improvements to archaeological and anthropological research that will further progress our understanding of children as active and engaged members of their societies.
\end{abstract}

${ }^{*}$ Corresponding Author at annemieke.milks@gmail.com 
Keywords: Hunter-gatherer archaeology; Forager children; Palaeolithic; Apprenticeship 


\section{Introduction}

Historically, research on the presence and active roles of children in the archaeological record primarily emerged from an agenda aiming to better highlight gender and identity in the past. Key early publications, such as 'A Child is Born' (Lillehammer 1989), 'Where are the Children?' (Derevenski 1996) and 'Where Have all the Children Gone?' (Kamp 2001) challenged the underlying assumption that the archaeology of childhood was constrained by low visibility. In the last decade, archaeological approaches to children have progressed significantly. Researchers have now moved beyond merely identifying children's presence to demonstrating that they were active and influential members of their societies (e.g. Cooney, 2018; Riede et al., 2018). The net result is that we no longer view past children as 'underdeveloped versions' of adults (Gamble 1999; Joyce 2006; Mithen 1995; Roveland 2000; Schwartzman 2006). While there is a rich body of research on children of sedentary societies, we know much less about childhood in small-scale societies which engage in greater mobility and fission-fusion. To fill this gap, the present paper aims to provide a systematic literature review of the current archaeological evidence for $H$. sapiens hunter-gatherer children.

The term 'hunter-gatherer' has attracted debate and criticism (e.g., Finlayson and Warren 2010; Barnard 2004; Warren 2021). A $19^{\text {th }}$ century colonial classification for human societies based on economic criteria only, the term continues to be common in the fields of archaeology and anthropology. While we refer to hunter-gatherers throughout the text, we acknowledge that there are shortcomings associated with a term which emphasises economy above cultural criteria. Further, we acknowledge that there was likely significant cultural and social variability amongst hunter-gatherer groups in the past, with few or no universalities (Warren 2021). Still, there remain some commonalities (Warren 2021). By employing a cross-cultural approach, researchers can develop useful frameworks for understanding these commonalities, alongside accounting for social plasticity (e.g. Wengrow and Graeber 2015). Investigating similarities and differences among past hunter-gatherer societies can thus help researchers approach evidence from new perspectives, and may assist us in both theory and method-building (Warren 2021).

Hunter-gatherer children deserve the attention of archaeologists for a variety of reasons. First, children were demographically significant members of their societies who consumed resources, made significant economic and social contributions, and influenced the archaeological record (Baxter 2008; Callow 2006; Lancy 2017; Cooney 2018; Crawford 2009; Hammond and Hammond 1981; Hildebrand 2012; Kamp 2015; Lillehammer 2010a; Nowell 2015a; Politis 1998; Riede et al. 2018; Roveland 2000; Schwartzman 2006). Second, studying children's material culture and their interactions with space and place can help us understand the learning, transmission, and innovative features of a given cultural taxonomy, as well as make broader cross-cultural comparisons (Lew-Levy, Milks, et al. 2020; Nowell 2015a; Lancy 2016, 2017; Riede et al. 2018). Third, understanding children's involvement in the formation of the archaeological record can shed light on site function (Politis 1998, 1999) as well as on their interactions with other children and adults, and thus, a group's social structure (Cooney 2018; Kamp 2015). Finally, evolutionary changes in human cognition can be better understood by investigating how children learned and were taught in the past, particularly in relation to material culture and technology (Högberg and Gärdenfors 2015).

Our paper is organized as follows: First, we describe childhood and learning in contemporary hunter-gatherer societies. We then summarise archaeological evidence attributed to huntergatherer children, and outline the methods used to evaluate this evidence. Next, we highlight the patterns and variability of children's material culture. Finally, we point to potential areas for future research. We acknowledge that the broad range of examples presented in this paper reflect significant cultural, geographical, and temporal diversity (e.g. Kelly 2013; Kuhn and Stiner 2001, p.123; Lemke 2018, p.8). We further recognise that tracking mobile societies who did not use textual sources in the deeper past comes with numerous challenges to identifying 
fine-grained evidence for individual activities. Nonetheless, we hope that this broad review will enrich and help to advance the study of childhood in the past.

\section{Ethnographic research on hunter-gatherer childhoods}

The present paper offers a review of archaeological studies which report possible evidence of hunter-gatherer children's objects and activities in the past. As such, our review is not only a report of material evidence, but also of its interpretation. In this section, we aim to expand the archaeological interpretative possibilities by describing childhood and learning in contemporary hunter-gatherer and other small-scale societies (Lew-Levy et al. 2017, 2018; Lew-Levy, Milks, et al. 2020; Reckin et al. 2020; Lancy 2016, 2017). We do not claim that contemporary hunter-gatherers represent an analogy to our ancestral past (see also Athreya and Rogers Ackermann 2018; Audouze and Janny 2009; French 2019; Gosselain 2016; Milks 2020; Lavi et al. in press). Instead, we argue that by calling upon ethnographic accounts from contemporary hunter-gatherer societies, we can shed light on aspects of childhood (e.g. socialisation, inter-personal interaction) that are usually intangible in the archaeological record. In doing so, we hope to provoke discussion regarding the important role of children in the present and past, as well as highlight how culture shapes variation in childhood experiences and development. In what follows, we outline general trends regarding children's incorporation into social and subsistence activities, autonomy, and use of material culture. Contemporary hunter-gatherers are culturally, geographically, and ecologically diverse, resulting in variation in childhood experiences (Konner 2005). While, for the sake of brevity, we focus on cross-cultural commonalities, we acknowledge that there are necessarily exceptions to these trends.

Hunter-gatherer children in many contemporary societies are integrated into the social and subsistence lives of their communities from an early age (Lew-Levy et al. 2017). In his comparison of nine hunter-gatherer societies, Konner (2016) shows that infants are in close physical proximity to caregivers throughout the day. For example, Aka infants are often carried in a sling or are sat in a caretaker's lap facing forward to facilitate social interaction with other community members (Hewlett and Roulette 2016). Infants often accompany their parents on foraging expeditions (e.g. Aka, Hewlett et al. 2011; Batek, Lye 1997, Nukak, Politis 2007; Awa, Politis et al. 2013). When parents are working, infants are often placed high on the mother's back, where they can peer over her shoulder while she works (e.g. Hadza and BaYaka, LewLevy et al. 2019). Many societies measure child development using milestones primarily grounded in cooperative behaviour such as sharing, the control of anger, and knowledge of kin relations (e.g. Nayaka, Bird-David, 2008; Inuit, Briggs, 1978, 1970; Walpiri, Musharbash, 2011).

Hunter-gatherer children are granted extensive personal autonomy to learn and explore (see Gardner 1991 for review; also BaYaka, Boyette and Lew-Levy 2021; Batek, Endicott 2011; Paliyan, Gardner 1966; Nayaka, Lavi in press; Naveh 2016; Baka, Sonoda et al. 2018). The autonomy afforded to children expands as they age. By approximately seven years of age, children in many hunter-gatherer societies spend much of their time in self-directed learning in the playgroup (Lew-Levy et al. 2017, 2018; see also Konner 2005; 2016). The playgroup primarily consists of cohabitating multi-aged, mixed-gender siblings, cousins, and peers. In these groups, children participate in work-themed play (see Boyette, 2016 for review). For example, making small play huts in or on the periphery of camp is described in almost all ethnographic texts on hunter-gatherer children (see Lew-Levy et al. 2017 for review). Near these huts, children emulate subsistence activities such as tuber digging, hunting, and cooking. Children may construct play huts with smaller and/or expedient materials, reflecting their smaller bodies (Fig. 1; Dukha, Mackie et al. 2015). While there are few gender differences in behaviour in early childhood (Nukak and Awa, Politis personal comm; Lew-Levy et al. 2018), children's work-themed play tends to mirror the sexual division of labour in their society as they grow older (e.g. Okavango Delta, Bock and Johnson, 2004; Parakaña, Gosso, 2010). 
The playgroup also serves as a setting for participation in foraging tasks (e.g. Mardu, Bird and Bliege Bird, 2005; Meriam, Bliege Bird and Bird 2002; Hadza, Crittenden et al. 2013; Mikea, Tucker and Young 2005). For example, Hadza children collect weaverbirds using sticky traps, a technology not used by adults (Crittenden 2016).
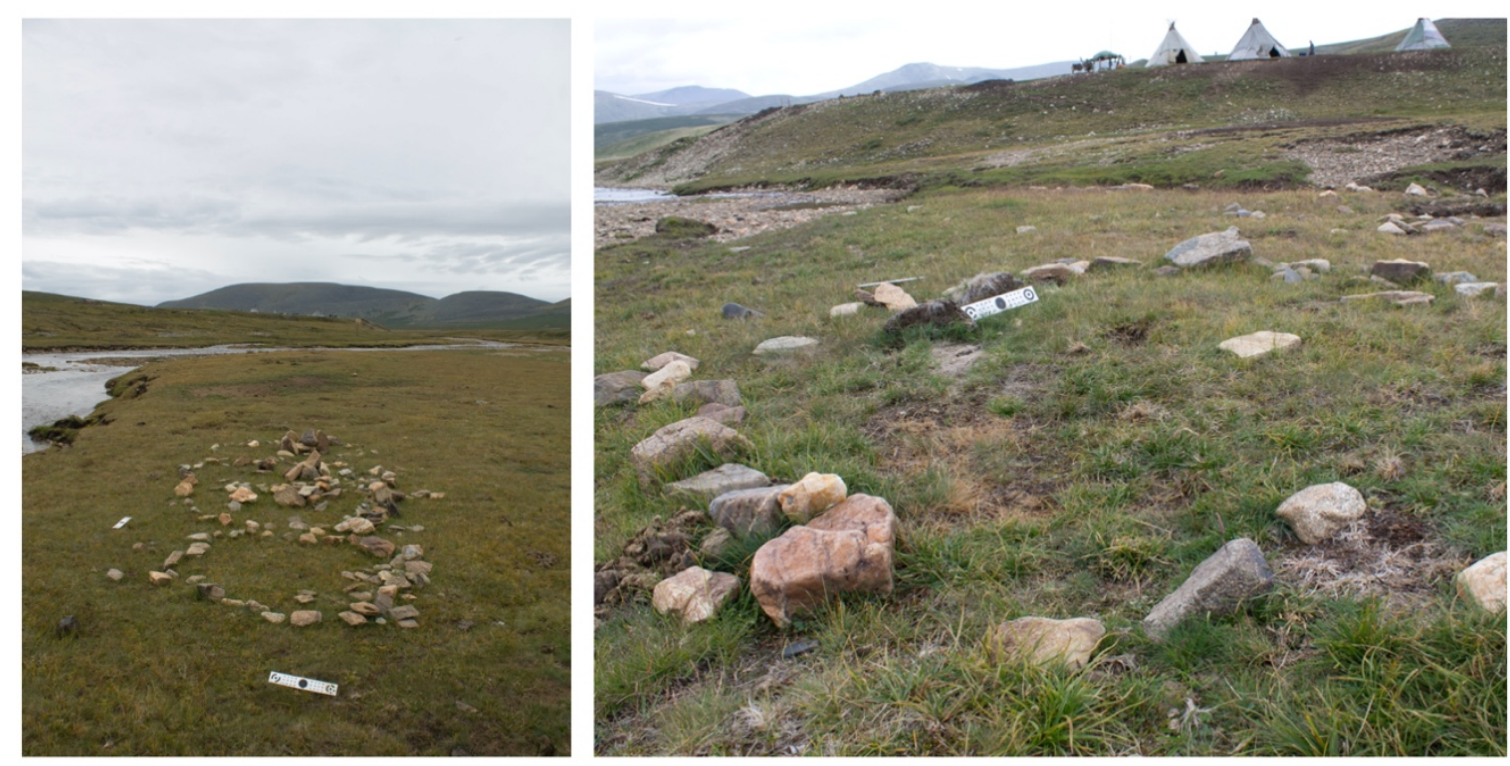

Figure 1. Stone alignments made by Dukha children on the periphery of the main camp. Left: Adjacent playhouse in the foreground, located at some distance from the main camp in the background. Right: A playhouse located closer to the main camp. Stones in the centre likely represent stoves. Photos courtesy of Todd A. Surovell. Copyright: Todd A. Surovell.

The availability of material culture plays an important role in hunter-gatherer children's socialization (Lew-Levy et al. 2017; Lancy 2016, 2017). From infancy, many hunter-gatherer children have access to adult tools, including knives, pounding stones and machetes (e.g. Hadza, Crittenden 2016; Mbendjele, Lewis 2002; Batek, Lye 1997). Young children are sometimes handed these tools to distract them while parents complete subsistence tasks (e.g. Aka, Hewlett et al. 2011). In early childhood, parents make small versions of adult tools, such as fishing line, baskets, digging sticks, spears, blow pipes, and bow and arrows for children to play with (e.g. Hadza, Crittenden 2016; Chabu, Dira and Hewlett 2016; San, Imamura 2016; Gidra, Nishiaki 2013; Kaytetye, Thompson 2003; Nukak, Politis 1998, 2007). Among the Gidra, parents view the gift of bows and arrows to young children as a form of teaching; children are expected to learn to produce these tools through reverse engineering (Nishiaki 2013). By four or five, children in many hunter-gatherer societies begin making their own tools (e.g. San, Imamura 2016; Imamura and Akiyama 2016; Batek, Lye 1997; Kaytetye, Thompson 2003). Several authors note that children refine their tool making capabilities by observing and being taught by adults and other children (San, Draper 1976; Imamura and Akiyama 2016; Aka and Chabu, Hewlett 2021; Khanty, Jordan 2014; Batek, Lye 1997; Kaytetye, Thompson 2003).

\section{Methods}

\subsection{Search methods and Inclusion Criteria}

We retrieved and sorted relevant papers using a systematic protocol outlined in Figure 2 (Moher et al. 2009). Using the keywords "hunter-gatherer" OR "forager" paired with "transmission" OR "child" OR "skill", we searched the following databases: Jstor, Springer, Wiley, and ScienceDirect. We searched through other relevant publications, including the archaeological journals published by the American Anthropological Association, Childhood in 
the Past, Hunter-Gatherer Research, American Antiquity, Latin American Antiquity, and Antiquity. We searched for unpublished dissertations and theses using ProQuest, and for books on the UCL library database.

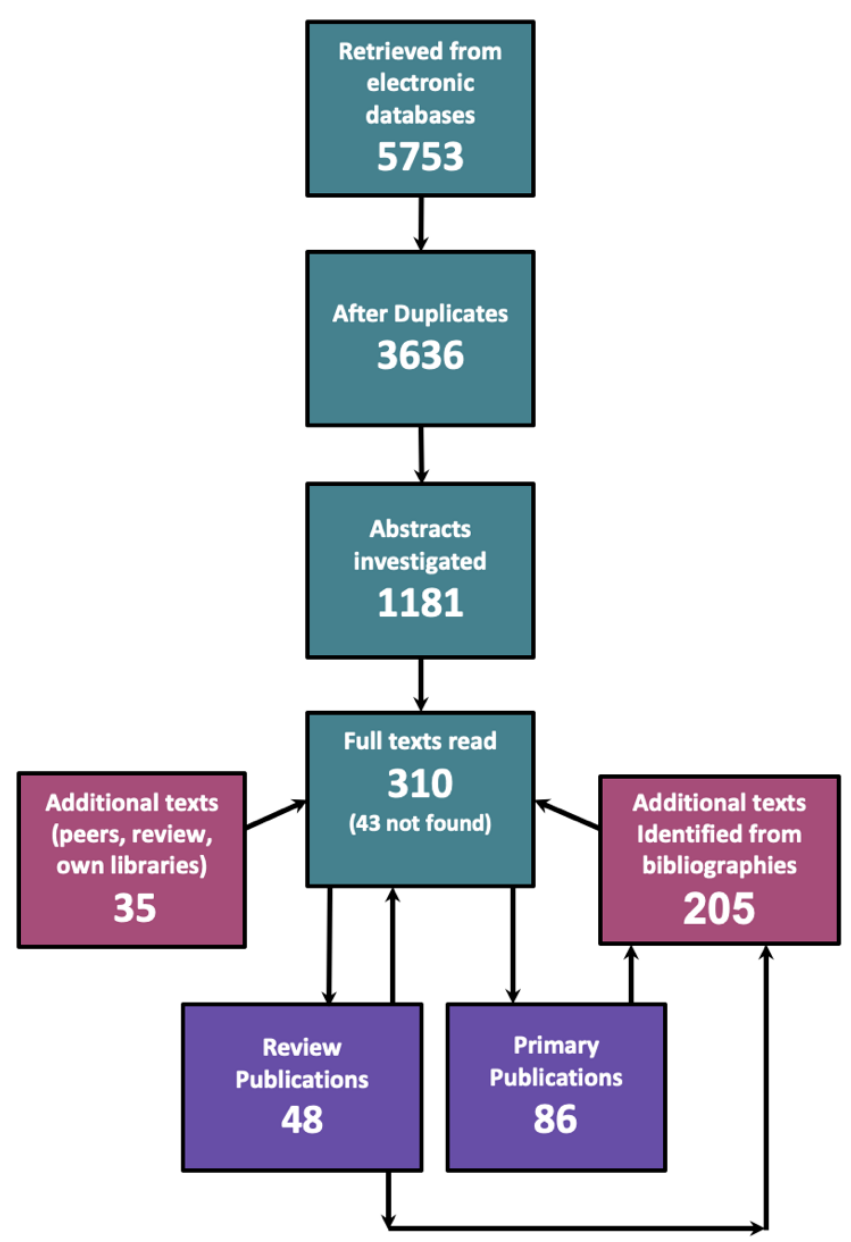

Figure 2. Flow chart of the paper retrieval process. Texts could be excluded at any stage if they did not meet the criteria, had quality issues, were not found, or were duplicates from a previous search phase. For every included text and review, we searched through the bibliographies for additional relevant papers. We repeated this process until no new relevant papers were found. The total in box "full texts read" represents the sum of full texts read at the end of this iterative process.

After removing duplicates, we screened titles and keywords, and then abstracts, for relevance. We also retrieved papers known by the authors to have potentially relevant data, but which had not been indexed during the initial search. AM and SLL independently assessed all relevant full texts for eligibility. While only papers which included primary data were considered eligible (see below), we flagged relevant review papers. To ensure that all relevant publications were successfully retrieved, we took two additional steps. First, we searched through the bibliographies of all papers which met our eligibility criteria. Second, we searched through the bibliographies of all indexed review papers. All titles were screened, and the full text of any papers potentially containing relevant data were assessed against our eligibility criteria. Additional publications were recommended during the peer review stage, which we 
also screened against our eligibility criteria. We repeated this process of search, retrieval, and assessment, and bibliography review until no new texts were identified.

To be eligible for inclusion, extracted papers had to include primary data on hunter-gatherer children or hunter-gatherer learners, as defined by the authors of the text. Papers had to focus primarily on archaeological data, though papers which used experimental and/or ethnographic data to contextualise specific archaeological sites or assemblages were included. Some papers which lacked critical information such as dates, location, context, or a clear method of analysis, were excluded.

We excluded data on burials, artistic depictions of children, and data on other Homo species. Burials were excluded from this review for several reasons: There are existing reviews on this subject, particularly in relation to child burial in the Eurasian Upper Palaeolithic (e.g. Cooney 2012; Formicola 2007; Mussi 1986; Nowell 2021; Pettitt 2013; Riel-Salvatore et al. 2001; RielSalvatore and Gravel-Miguel 2013). Burials have myriad challenges including difficulties in correctly estimating age from mortuary remains (Cooney 2012) and interpretive limitations of relating grave goods in ritual contexts to the lived experiences of children (Lillehammer 2010a). Many excavations of burials were undertaken before the establishment of modern excavation techniques, and the dispersed location or total loss of archaeological and bioarchaeological material can make systematic analyses particularly challenging (e.g. Sparacello et al. 2018). However, we included selected references to grave goods that were interpreted as illuminating aspects of the lifeways of children. We did not include purported artistic depictions of children because these are both rare and interpretatively limited (Roveland 2000). Archaeological artistic representations of children from hunter-gatherer cultures are rare, and since the focus of this paper is material culture attributed to children themselves, we do not cover them here (but see Nowell 2021 for a review). This paper is restricted to a review of archaeological evidence attributed to $H$. sapiens because relevant and informative publications regarding the childhood of other Homo species have explored miniatures, footprints, evidence of learning to knap, objects associated with child burial, and learning behaviours (e.g. Ashton et al. 2014; Assaf et al. 2016; Nowell and White 2010; Spikins et al. 2014; Stapert 2007; Terashima 2016).

There are some limitations to our review that bear mentioning. First, books and older articles are unlikely to be indexed, and data within print books also would not come up in the search if our relevant search terms are not in the title. Second, when they arose in the sorting process, we included papers in languages for which we have collective reading competence (French, Spanish, German, Italian) but additional non-English publications were likely not retrieved. Finally, presumably a higher percentage of archaeological sites have evidence of children than just those presented here, but we could only include papers where authors have directly related sites and artefacts to children's activities.

In total, 86 publications were considered eligible to be included in the present review paper. Each was read critically, and content was organized and coded by emerging themes, cultural designations, dating, and geographical regions. 48 publications were identified as review papers, and are cited where appropriate. Throughout, dates and cultural attribution are provided as reported in their original publications.

\subsection{Definitions}

How societies define 'children' and 'childhood' is culturally variable (Cooney 2018; Lillehammer 2008). Childhood is defined both biologically by children's physical and cognitive development, and constructed socially, based on cultural values and beliefs about child development, economic responsibility, and position within the community (Baxter 2008; Cooney 2018; Kamp 2015; Lillehammer 2010a; Lillehammer 2010b; Schwartzman 2006; Temple 2018). Because of this complexity, we chose to follow each study's authors' own 
definition of 'children'. In so doing, we have surveyed a wide variety of findings from the preadult stage, encompassing infancy (approx. 0-2 years), early childhood (approx. 3-6 years), middle childhood (approx. 7-12 years), and adolescence (approx. 13-18 years), covering a wide range of physical and cognitive developments and abilities, and representing a key period for acquiring social, physiological, technological, and ecological skills (Cooney 2018; Imamura 2016; Kamp 2015; Nowell and White 2010).

'Skill' is an important feature of many archaeological studies of hunter-gatherer children, particularly those that relate to learning to produce lithics and art. Skill is acquired through active individual and social processes, and can involve both knowledge in a cognitive sense and capability in a physical sense (Bamforth and Finlay 2008; Ferguson 2008; Miller 2012; Finlay 2015; Karlin 1991). Since much of childhood is devoted to learning (Baxter 2008), archaeological evidence for skill acquisition is often attributed to children. However, there are shortcomings to this approach. First, recognizing skill can be problematic because we may impose modern ideals, including aesthetic considerations or displays of expertise, on prehistoric artefacts that may not have been relevant or that may even have been suppressed in the past (Darmark 2010). Second, it can be difficult to quantify skill simply on the basis of mistakes because anyone, including experts, can make mistakes, and poorly made tools may not necessarily reflect experience (Finlay 2008). For this reason, a single error does not usually indicate the presence of a novice or child, whereas a clustering of them may be a better indicator. On the other hand, the products manufactured by particularly skilled children may be mistaken for those of adults (Bamforth and Finlay 2008). Finally, ethnographic studies suggest that the acquisition of more specialized skills, such as big game hunting, develops during childhood and into adulthood (e.g. Koster et al., 2020). Nonetheless, many scholars support the assertion that most subsistence and social skills are acquired by adolescence (see Lew-Levy et al., 2018, 2017 for review on contemporary hunting and gathering societies).

\section{Results}

Primary data papers were published between 1952 and 2021. The median date was 2010, showing that at least half of the primary data papers were published in the last decade, and $77 \%$ of the papers $(n=66)$ were published since 2000 . This likely reflects the overall increased pace of academic publishing, the increase of digital publications (which our methodology inherently prioritises), and an increase in research on children.

Lillehammer's (2008) assertion that research on the archaeology of children is Eurocentric is largely upheld. $65 \%$ of publications relate to Eurasia ( $n=56$, including western Russian sites) followed by $19 \%$ of publications pertaining to archaeological sites in continental North America ( $n=16$, including Greenland). A handful of papers focus on archaeological sites in eastern Asia (Takakura 2013), South America (Bayón et al. 2011; Bayón and Politis 1996; Bobillo and Hocsman 2015; Nami 2007, 2013; Onetto and Podestá 2011; Politis 1998), Australia (Franklin \& Hagbood 2009; Hallam 1971; Van Gelder 2015a; Webb et al. 2006), and Africa (Högberg and Larsson 2011; Lombard 2015), while three papers that make cross-continental comparisons including between Europe and Australia (Bednarik 1986) and Europe and North America (Weedman 2002; Riede et al. 2018).

Sternke and Sorensen (2009) claim that the research on children in archaeology is predominantly undertaken by female researchers. Although this was true of the 48 review papers included, with $37.5 \%(n=18)$ having a male first author and $63.5 \%(n=30)$ a female first author, we did not find this to be the case for primary data papers, with $56 \%(n=47)$ having a male first author and $44 \%(n=37)$ a female first author. We can contrast this with the overall trend of the gender of first authors in American archaeological papers. Out of a sample of 4,552 articles published between 1990 and 2013 from 11 peer-reviewed journals, $71 \%$ of the sample had a male first author (Bardolph 2014). With a more equal balance in first authorship reflected in our review, it may well be that female archaeologists remain more likely than males 
to look for evidence of and ask questions about hunter-gatherer children. However, direct comparisons are difficult given the more global nature of the authorship of our papers compared with Bardolph's 2014 study.

We grouped publications by broad themes that emerged during the sorting and reading process. These themes include Children's Playthings and Learning Tools $(n=20 ; 23.3 \%)$, Learning to Knap $(n=39 ; 45.3 \%)$ and Children Making Art, Marks and Tracks $(n=27 ; 31.3 \%)$. Some papers fall into multiple categories, such as where evidence of children knapping may also include possible evidence of toys or play (e.g. Jacobi 2004), or where evidence of children making marks on cave walls intercepts with play (Romano et al. 2019; Sharpe and Van Gelder 2006; Van Gelder 2015b). We cover each of these main categories in detail below, and then explore overarching themes in the Discussion. For brevity and clarity, dates and cultural taxonomies for all primary data papers can be found in Tables 1-3, and will not be repeated throughout the paper.

\subsection{Children's playthings and tools}

Play is a cross-cultural phenomenon, and therefore searching for evidence of it in the archaeological record is a worthwhile method for identifying the presence of children (Högberg 2008; Nowell 2016; Langley and Litster 2018). 'Play' encompasses 'any activity that encourages exploration, imitation, and experimentation with material objects, social roles, and interactions with other people' (Cooney 2018, p. 5). Playthings, or toys, are material manifestations of play (Crawford 2009). This review includes artefacts from all three of Crawford's (2009) categories of toys, including those argued to be formalised toys (Dawe 1997; Hardenberg 2010; Park 1998), adult objects that may have been 'recycled' as playthings (Langley 2018), and expedient objects, materials, or manuports that could have served as toys (Jacobi 2004; Politis 1998; Romano et al. 2019).

While objects relating to children's play likely made up a large proportion of the material culture of past hunting and gathering societies, these objects are either rarely discovered, or rarely identified as children's toys by archaeologists. Furthermore, the classification and use of objects as 'toys' can be fluid; some can be classified both as tools and playthings, and depositional pathways-why and how objects entered the archaeological record-can be unclear (Crawford 2009). In spite of challenges in recognising toys, by re-examining archaeological assemblages and comparing them to the activities of extant hunter-gatherers, several archaeologists have attempted to assess whether artefacts may represent children's toys, including in South America (Politis 1998; Nami 2007), North America (Dawe 1997; Ellis 1994; Frison 1970a, 1970b; Hardenberg 2010; Kenyon and Arnold 1985; Park 1998, 2006; Riede et al. 2018), and Eurasia (Jacobi 2004; Langley 2018; Riede et al. 2018). A full accounting of children's playthings covered in this review can be found in Table 1.

\subsubsection{Formalised toys}

Kenyon and Arnold (1985) place children's playthings into two categories: pastimes and imitation. Figurines and dolls, which are sometimes interpreted as relating to adult material culture, are known from North American and Eurasian contexts (Kenyon and Arnold 1985; Langley 2018; Park 1998; Riede et al. 2018; Lbova 2021). Games are also evidenced (Kenyon and Arnold 1985). Discs carved out of bone, ivory or stone are known from Eurasian Upper Palaeolithic contexts and have been found associated with child burials (Sieveking 1971). Although they are traditionally interpreted as pendants or buttons, those engraved with different images on each side, also called 'thaumatropes', have also been interpreted as 'optical toys' as spinning between the two images can create the illusion of movement (Azéma and Rivère 2012; Langley 2018; Riede et al. 2018). Imitative toys include remnants of miniaturised weaponry (Dawe 1997; Kenyon and Arnold 1985; Langley 2018; Park 1998; Politis 1998), end scrapers (Dawe 1997), harpoon heads (Kenyon and Arnold 1985; Park 
1998, 2006), and transportation tools such as small sleds (Kenyon and Arnold 1985; Park 1998). We found two examples of potential toys associated with child burials: a burial of a sixyear-old child in Lovelock Cave (Nevada, USA) included a sling (Heizer and Johnson 1952), which on the basis of recent historical data is interpreted by the authors as a toy. In another instance, Politis (1998) identifies a black basalt ball, associated with a child burial in the Pampean region (Argentina) dated to ca. $6400 \mathrm{BP}$, as being a toy on the basis of ethnographic comparison.

The most vivid descriptions of children's play objects and play spaces come from Thule people, who inhabited Arctic Canada and Greenland beginning in approximately $1000 \mathrm{BP}$ (Park 1998, 2006). An archaeological survey by Hardenberg (2010) of Thule sites in Greenland identifies several different types of playhouses, including winter houses, summer tent rings, and doll houses. In playhouses that imitated winter structures, platforms were placed at the rear or side of the house, with white and red stones in 'caches' on sidewalls, likely representing blubber and meat respectively, and with paved floors and entrances. These houses were primarily constructed in the spring and summer, when stones were accessible to children and children could easily play outside. In a recent paper, Langley (2020) explores some specific tent locations at the Magdalenian site of Étiolles (France), which are of overall smaller size, contain smaller hearth stones, and display a relatively limited lithic record, absence of ochre and ornaments in comparison to larger tent locations. The archaeological record of these particular areas ( $\mathrm{G} 13$ and $\mathrm{J} 18)$, at site where the presence of children is already well-accepted, suggests the presence of dedicated play areas at larger residential sites.

\subsubsection{Expedient playthings}

There are multiple lines of evidence for children's use of natural objects and materials during play (see also Section 5.3). For example, Romano et al. (2019) argue that children played with clay in Bàsura Cave (Italy), dated to ca. 12,340 BP, a material also used by Upper Palaeolithic artists (e.g. Farbstein and Davies 2017; Garate et al. 2020). Similarly, scholars suggest that children likely played with stone (e.g. Karlin et al. 1993; Ortega-Cordellat 2018). Although Jacobi's (2004, p. 77) suggestion that seashells in Gough's Cave (U.K.) were potentially brought to the cave 'in a child's pocket' is evocative, it is difficult to attribute manuports to children, particularly given that objects such as shells were generally important cultural objects in hunter-gatherer societies of the past (but see Langley and Litster 2018).

\subsubsection{Repurposed adult objects}

One difficulty in identifying children's material culture is that they can involve raw materials or tools that may have been discarded by adults, or repurposed for children (Karlin et al. 1993; Langley 2018; Politis 2005). For example, some Upper Palaeolithic osseous projectile points were refashioned as pendants, and those bearing poorly drilled holes may represent the repurposing of adult tools by or for children (Langley 2018). Langley (2018) proposes that artefacts may enter a 'toy stage' at the end of their functional use-life. This may particularly be the case for objects that were highly curated. Langley's study of Upper Palaeolithic osseous tools has also highlighted the potential for identifying children learning practical skills beyond the data gleaned from the lithic record. In particular, poorly reconstructed osseous points from Magdalenian sites may represent children learning weapon maintenance, which would have been an important skill amongst communities relying heavily on hunting for survival.

\subsubsection{Children's tools}

The design, materials, and sizes of toys sometimes suggest that they were used for learning. For example, some toy bows from Canadian Thule sites were not spliced (unlike those of adults), and seemed too small to function (Kenyon and Arnold 1985). Thule recurved baileen 
bows could have been strung and used by children in the context of hunting while wood double reflex bows may have been used by adolescents, potentially representing the last toy bow stage before adulthood (Kenyon and Arnold 1985). Park (1998) compares artefacts from archaeological sites attributed to the Thule and Dorset cultures. Dorset peoples inhabited Arctic Canada and Greenland from ca. $1500 \mathrm{BP}$ to ca. $1000 \mathrm{BP}$, while Thule inhabited the region from ca. 1000 BP (Park 1998, 2006; Park and Mousseau 2003). Park (1998) investigates miniature and full-sized artefacts, and notes that toy bows make up a larger proportion of miniatures than the proportional representation of full-sized bows in the full-sized assemblage. This finding accords with ethnographic observations among the Inuit, where fathers teach both boys and girls to use bows (Park 1998). Smaller barbed antler points from the Early Mesolithic site of Star Carr (U.K.) are also argued to have been functional hunting tools designed for learning purposes (Elliott 2009, p. 101). Similarly, atlatl fragments from the Par-Tee site (Oregon, USA) represent a range of sizes to fit different hands, including those of children (Losey and Hull 2019). The smallest two atlatls suggest a grip as much as $40 \%$ smaller than the largest in the sample (Fig. 3), and sexual dimorphism is ruled out as the sole reason for size variation. The authors argue that the use of whalebone to produce the childsized weapons indicates that these were not intended just for play, but also to enskill younger group members for hunting (Losey and Hull 2019).
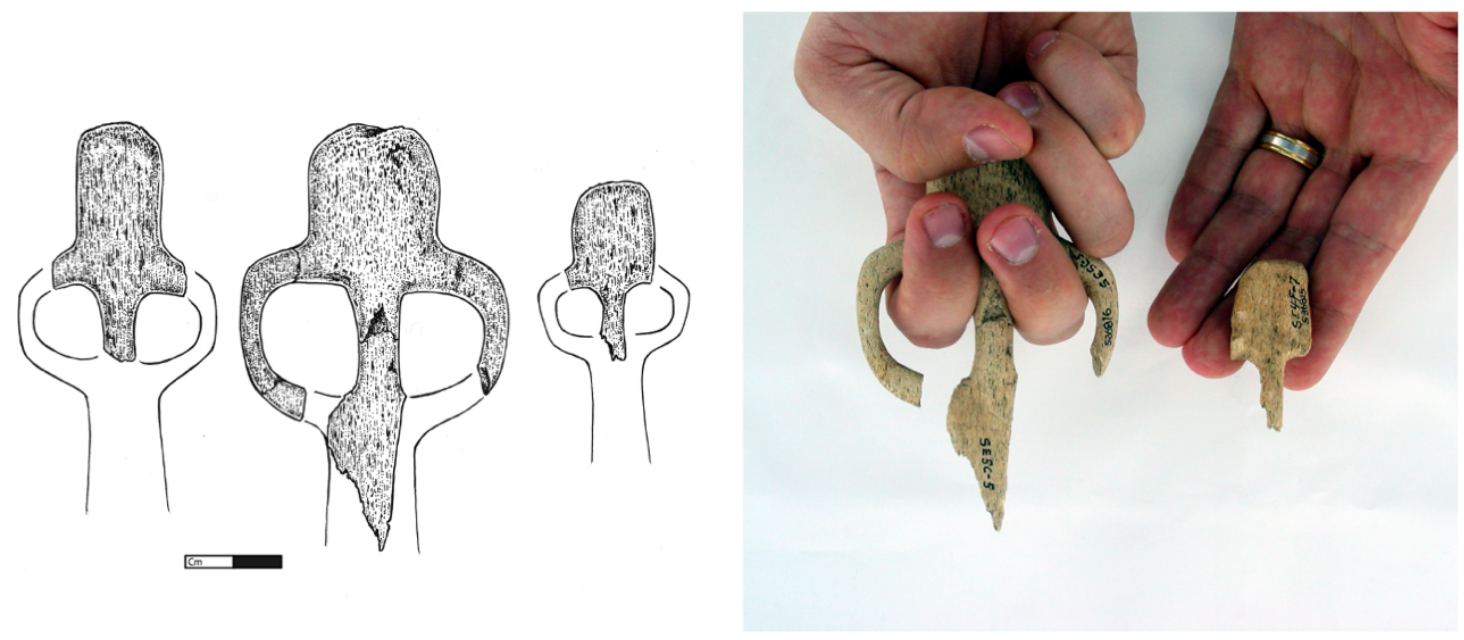

Figure 3. Left: The most complete Par-Tee Type-one atlatl grip (centre 536816), and the two smallest grip fragments (left 541034; right 536815) (illustration by E. Hull). Right: Type-one atlatl grips (536816 and 536815) in the hands of Robert Losey (Photograph by R. Losey). Note the difference in sizes between the widths of the palm pads. Courtesy of Robert Losey, Emily Hull, and Antiquity journal. From Losey and Hull 2019: https://doi.org/10.15184/aqy.2019.172

\subsubsection{Debates about scale}

Scale may be insufficient for identifying children's playthings (Politis 1999). In comparing Thule and Dorset archaeological sites (Canada and Greenland), Park (1998) finds hundreds of miniatures interpreted as toys among the Thule, while fewer miniatures could be identified as toys in Dorset archaeological assemblages (Park and Mousseau 2003). Instead, many of the Dorset harpoon heads were better understood as functional hunting tools (Park and Mousseau 2003). A wooden artefact from the Magdalenian site of Mannheim (Germany) illustrates another obstacle to attributing artefacts to children on the basis of size: this fragmented artefact may be the fragment of a child's bow, but its true function remains uncertain 
(Rosendahl et al. 2006). Even if interpreted as a bow, its size compared with ethnographic examples falls within both the known range of both children's and adult bows (Rosendahl et al. 2006).

With lithics, several authors have argued that miniature projectile points or other tool types could be interpreted as children's toys if they are small, relatively poorly-made, and show some evidence of use or refurbishment (eg. Ellis 1994; Guarino and Sellet 2019; Flegenheimer et al. 2015). Small objects may also simply represent raw material conservation (eg Guarino and Sellet 2019), symbolic objects (eg Ellis 1994), or functionally distinct items used by adults (eg Buchanan 2006). Small, nondescript and poorly made projectile points from Late Prehistoric contexts at Northern Plains buffalo hunting and processing sites, including the Kobold Bison Jump (Montana, USA), Glenrock (Wyoming, USA) and Head-Smashed-In (Alberta, Canada) (Dawe 1997; Frison 1970b, 1970a). These smaller projectile points have broadly been interpreted as children's weaponry, and may have been functional (Dawe 1997; Frison 1970a, 1970b). Archaeologists also found a miniature arrow shaft smoother at the Head-Smashed-In processing site, which may reflect the manufacture of miniature weapons by children. For Elliott (2009, p.101), the deposition of smaller barbed points alongside full sized examples suggests that these were functional 'learner' points. In contrast, Ellis (1994) argued that miniature points from the Parkhill Site (Ontario, Canada), were neither toys nor utilitarian, as they were minimally retouched and show no evidence of use. Ellis (1994) concluded they were therefore ideotechnic. Following Politis' (1998) description of smaller and poorly made Fishtail projectile points discovered in Argentina as tools manufactured by children, Nami $(2007,2013)$ found further evidence at Uruguayan sites that Fishtail points, often with abraded edges that they argue may have made them safer for children. In contrast, Flegenheimer et al. (2015) and Flegenheimer and Weitzel (2017) propose that small Fishtail points from Cerro El Sombrero Cima (Buenos Aires province, Argentina) were never hafted and never used to work organic material, and therefore may never have been used. As a result, Flegenheimer and Weitzel (2017) conclude these points may reflect symbolic behaviours (see also Miotti and Terranova 2015).

\subsubsection{Debates about preservation}

Some authors argue that children's tools and toys were more frequently made of organic materials than objects attributed to adults. Stiner et al. (2003) make the case that technologies such as traps, snares and nets, which may have been primarily utilised by children and female group members for hunting small prey, are ethnographically typically made of organics like cordage and wood that rarely preserve. Similarly, Nowell (2021, p. 144) reviews less archaeologically visible materials such as ceramics, art, and fibres. She remarks that the focus on bones and stones has created a 'tyranny of the tangible' which may particularly affect how we understand children's lives in the past. Park (2006) argues that many Thule toys were made of wood, while harpoon heads that had been identified by others as toys amongst Dorset sites were made of harder organics that are more likely to preserve. Park and Mousseau (2003) argue that the smallest Dorset harpoon heads may have been functional hunting tools designed for children, and/or were designed for smaller prey such as birds. Riede et al. (2018) suggest that instead the archaeological record may point to cultural differences, and that exposure to an exceptional diversity of technologies amongst the Thule may have been reflected in a wider array of toys. Thule children may have also spent more time in imitative play which left a clearer archaeological signature, while Dorset children may have primarily played with figurines or adult objects (Park 2006). In sum, it remains difficult to discern how issues of preservation, or cross-cultural differences in play, affect the archaeological record. 


\subsection{Learning to knap}

Sites attributed to archaeological hunter-gatherer populations on several continents show evidence of children and adolescents learning to manufacture stone tools, details of which can be found in Table 2.

\subsubsection{Identifying novices and experts}

Overall, these studies identify several attributes pointing to a lack of both motor skills and mental templates which, when occurring simultaneously and frequently, suggest the presence of novice knappers:

- Battering and incorrect use of force to remove flakes resulting in strongly marked bulbs of percussion, evidence of lower precision and accuracy during knapping, or failed removals (e.g. Fischer 1990a; Grimm 2000; Janny 2010; Langlais 2018; Milne 2005; Takakura 2013; Bobillo and Hocsman 2015)

- Minimally modified, ineffectively prepared, and/or crushed striking platforms, suggesting poor or no core maintenance (e.g. Audouze and Janny 2009; Donahue and Fischer 2015; Fischer 1990a, 1990b; Grimm 2000; Högberg and Larsson 2011; Janny 2010; Milne 2005; Sternke 2011; Sternke and Sørensen 2009; Takakura 2013)

- Cores with removals that are irregular and/or demonstrate inaccurate and poorly executed strikes, or with minimal flake scars (see Fig. 4; e.g. Audouze and Janny 2009; Cattin 2010; Finlay 2008, 2015; Jacobi 2004; Klaric 2018; Petersen et al. 2015)

- Terminations that represent errors indicative of poor control during the knapping process (e.g. Audouze and Janny 2009; Cattin 2010; Cunnar 2015; Donahue and Fischer 2015; Dugstad 2010; Grimm 2000; Högberg and Larsson 2011; Janny 2010; Milne 2005; Ortega-Cordellat 2018; Sternke 2011; Sternke and Sørensen 2009; Takakura 2013; Bobillo and Hocsman 2015)

- Irregular blade production (e.g. Janny 2010; Sternke and Sørensen 2009; Takakura 2013) or failure to produce any or more than a few blades (e.g. Audouze and Janny 2009; Cunnar 2015; Dugstad 2010; Fischer 1990b, 1990a; Karlin et al. 1993)

- Sinuous edges on bifaces (Milne 2005)

- Limited evidence or irregular patterns of use wear (e.g. Donahue and Fischer 2015; Milne 2005; Rots 2005; Sternke and Sørensen 2009)

- Complete or near complete operational sequences with few or no products removed from the site, suggesting that they were executed for demonstration purposes (e.g. Bodu et al. 1990; Cunnar 2015; Dugstad 2010; Fischer 1990b, 1990a; Grimm 2000; Karlin et al. 1993, 1993; Takakura 2013)

- Selection of sub-optimal shapes and/or sizes of raw material or blanks for exploitation (e.g. Audouze and Janny 2009; Ortega-Cordellat 2018; Rots 2005)

- Poorly executed resharpening (e.g. Rots 2005; Simonet 2012)

Bodu et al. (1990) and Karlin et al. (1993) propose three stages of skill development. Stage 1: blocks of cracked flint on which tremendous efforts but inconsistent results are apparent. At this stage, children learn by imitating adults. Stage 2: serious but tentative knapping. Children have acquired some skills through experience, such as through play, and undergo an apprenticeship to refine these skills. Stage 3: progression in operational as well as conceptual mastery. Several authors suggest that learners in stage 1 worked with discarded cores (Bordes and Bachellerie 2018; Cunnar 2015; Dugstad 2010; Fischer 1990b; Karlin et al. 1993; Ortega-Cordellat 2018; Pigeot 1990; Sternke and Sørensen 2009) while learners in stage 2 had the conceptual knowledge but not the necessary motor skills needed to consistently produce well-made tools (Anderson 2018; Grimm 2000; Högberg and Larsson 2011; Karlin et al. 1993; Sternke and Sørensen 2009; Takakura 2013). Audouze and Janny (2009) further break down the above third stage into two stages of 'regular' and 'accomplished', suggesting a further level of expertise amongst adult knappers. An additional signal of skill level in regards to knapping may be the presence of asymmetry for points that are typically symmetrical in a 
given assemblage or technological tradition (e.g. Bamforth and Hicks 2008; Bobillo and Hocsman 2015).

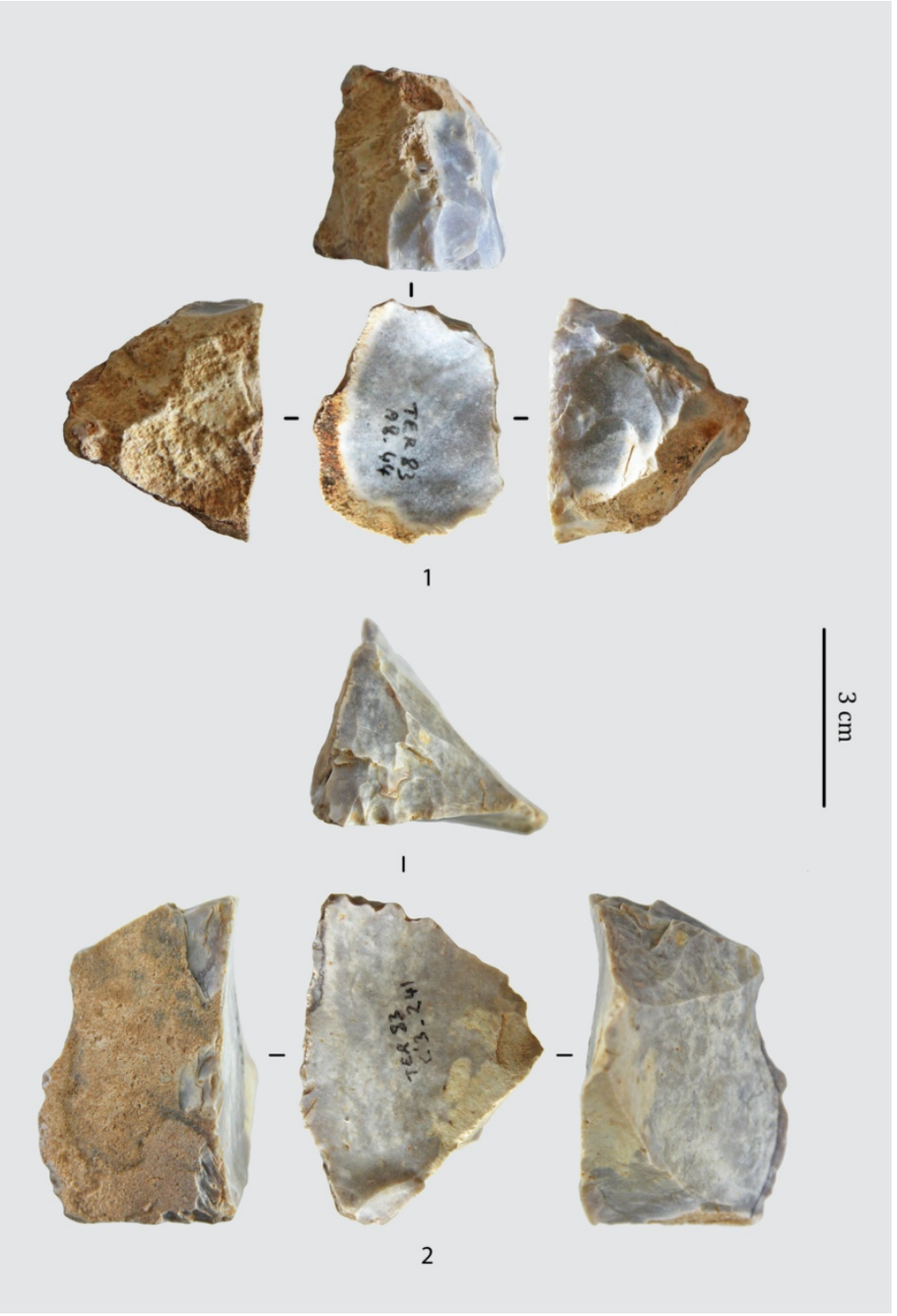

Figure 4. 1: a partially reduced preform and 2: a carinated core from Tercis (France), both attributed to beginners. Photos courtesy of Laurent Klaric. Copyright: Laurent Klaric.

These skill levels may also be reflected in the types of tools produced by knappers; Simonet (2018) suggests that intermediate knappers may have produced backed pieces, while higher skilled knappers may have produced backed points, blades, and cores (see also Debout 2018). In addition to the process of learning to knap, lithics can also indicate inexperience in use of stone tools. On the basis of ethnographic analogy, Weedman (2002) proposes that spurs on stone scrapers are neither functional nor stylistic, but rather result from inexperienced use during hide scraping activities. Rots (2005) identified inexpert resharpening attempts of an originally expertly-made stone scraper from the Magdalenian site of Verberie. This tool suggests that an irregular blade was chosen and manufactured by an experienced knapper for use by a child, who then attempted to clumsily resharpen it. Atypical use-wear on unusually small and poorly manufactured tanged points, which otherwise at Trollesgave (Denmark) would have functioned as projectile points, may have been repurposed by children for tasks such as woodworking or meat cutting (Donahue and Fischer 2015). 


\subsubsection{Spatial distribution of experts and novices}

Examining the spatial distribution of lithics potentially-attributable to novice knappers suggests that at some sites expert and novice knappers were in proximity to each other during manufacture, but occupied separate space (see Tostevin 2019). For example, at Etiolles (France), the 11 debitage clusters likely made by novices were located on the periphery of the habitation, while competent knappers worked closer to the hearth (Karlin et al. 1993; Pigeot 1990), a pattern that looks more or less consistent for Magdalenian sites throughout the Paris basin (Audouze and Cattin 2011; Bodu et al. 1990). The proximity between the expert and novice knapping zones at Hattoridai 2 (Japan) suggests that the groups of knappers were separate but still in proximity to one another (Takakura 2013). At the Late Palaeolithic sites of Hundvåg (Norway) and Trollesgave (Denmark), novice and expert knappers worked in closer proximity to each other but are still spatially distinct (Donahue and Fischer 2015; Fischer 1990b, 1990a). Similarly, at Solvieux (France), knapping products in Location 1 attributed to a novice led Grimm (2000, p. 64) to hypothesise that this was a zone reflecting 'benign community neglect [...] where they configure their own learning relations with other apprentices'. Similarly, Klaric (2018) notes a high concentration in a small area of poorly executed cores at La Picardie (France), and suggests that this may have been an area reserved for novice knappers. Such spatial distinctions could potentially represent children engaging in peer-to-peer learning, rather than exclusively learning skills from adults (Kamp 2015; Shea 2006).

Exceptions to this pattern of spatial differentiation include the Magdalenian sites of Champréveyres and Monruz (Switzerland); an early Mesolithic site, 'Site 3' on the island of Hundvåg (Norway); and the late Mesolithic sites of Ferriter's Cove and Derragh (Ireland) where products of novice and expert flintknapping overlap, with no clear observable spatial differentiation (Audouze and Cattin 2011; Cattin 2010; Dugstad 2010). Finally, the intriguing late Mesolithic site of Coulerlerach (Scotland) may have been a 'persistent place' with apprentices potentially revisiting locations where they had previously left traces of their younger selves learning to knap (Finlay 2015).

\subsubsection{Social interactions between experts and novices}

The resolution in the archaeological record is often coarse, and demonstrating true contemporaneity on a scale that clearly indicates 'teaching' is rarely possible. However, while the overlap or close proximity of different skill levels could indicate sequential events, their potential contemporaneity provides windows into methods of teaching and learning, and Finlay (2015) argues we must consider them carefully as such. Several sites have been argued to evidence potential interactions between experts and novices, leading to hypotheses that teaching was taking place (e.g. Cattin 2010; Dugstad 2010; Karlin et al. 1993; Ortega-Cordellat 2018). At two Early to Middle Archaic Great Basin sites (Nevada, USA), Cunnar (2015) notes that poor preforms are positioned in an arc around expertly produced debitage, suggesting formal apprenticeship. Similarly, at the Late Palaeolithic Bromme site of Trollesgave (Denmark), Fischer (1990b, 1990a) suggests that refitted clusters of debitage can be interpreted as a novice working in a distinct location, possibly while facing and observing an expert knapper seated on a large boulder. Högberg and Larsson (2011) underscore the social underpinnings of the processes of learning to knap, which may have combined formal teaching alongside practice and experimentation.

Some assemblages have been interpreted as 'academic cores' (Johansen and Stapert 2008), where an expert knapper demonstrated the manufacturing process from start to finish. At Magdalenian sites including Etiolles, Solvieux (both France), Champréveyres, and Monruz (both Switzerland), Upper Palaeolithic sites in the Bergerac region (France) and the Mesolithic Site 3 on Hundvåg (Norway), novice knappers interacted with previously exploited and sometimes exhausted cores (Cattin 2010; Dugstad 2010; Grimm 2000; Karlin et al. 1993; 
Ortega-Cordellat 2018; Pigeot 1990; Sternke and Sørensen 2009). Similarly, Finlay (2015, p. 108) reports the presence of 'mixed-ability cores' at the Mesolithic site of Lough Boora (Ireland), clustered around a chert block with an intact fossil shell. At Etiolles (France), cores of higher quality were worked by more experienced knappers, leading Pigeot (1990) to suggest that expert knappers distributed materials to novices, since the ability to evaluate the quality of cores is a developed technical skill. Cattin (2010) also describes a set of blocks that suggest active teaching at two Magdalenian sites in Switzerland. At the Japanese Paleolithic site of Hattoridai 2 (Japan) and Magdalenian Pincevent (France), some blade manufacturing was expertly done showing all stages of the process, yet both byproducts and products were left at the site (Bodu et al. 1990; Karlin et al. 1993; Takakura 2013).

\subsubsection{Availability of raw materials}

Several authors discuss the role of raw material availability in shaping children's learning experiences. Abundant raw materials provide opportunities to experiment independently, and the amount of raw material availability influences the amount of scaffolding provided to learners, such as direct assistance from experts with difficult aspects of a task (Eigeland 2011; Ferguson 2008). Learning flint knapping wastes a lot of material, leading Eigeland (2011) to hypothesise that in areas scarce in good quality raw materials, such as in eastern Norway, the training process may have been more intensely focused at specialised sites (see also Clark 2003). Taking a landscape approach, Eigeland (2011) only found clear evidence of novices at one of the six sites analysed. Similarly, an analysis of a selection of French and Swiss Magdalenian sites also found that certain sites with a dearth of good quality raw material have less evidence of the presence of children, while sites with more material have more evidence of practicing and teaching knapping (Audouze and Cattin 2011). Similarly, Bobillo and Hocsman (2015) argue that lithic quarries were exploited by hunter-gatherer groups with nearby residential sites. At locations in the quarries with evidence of biface manufacture, linked to hunter-gatherer toolkits, they suggest that whole societies, including children learning to knap, visited the quarry sites, as evidence by knapping errors and differentially executed finished tools. An abundance of material points to the locales being repeatedly used for teaching and learning (Bobillo and Hocsman 2015). However, Bamforth and Hicks (2008) found evidence for the presence of children knapping at residential sites in Medicine Creek Drainage (Nebraska, USA), but not at workshop sites. The authors propose that this difference is not attributable to variation in raw material availability at these sites.

The quality of material at a site may also determine what gets exploited by whom. For example, raw material may have influenced the age and stage of learning amongst pre-Dorset peoples on Baffin Island (Canada), where chert is only available inland and during the summer months (Milne 2005). Milne (2005) suggests that the dedicated learning of knapping was reserved for older adolescents who could make the trek inland, select nodules, and carry them some $10 \mathrm{~km}$ from the source of the raw material to a lithic workshop. At Hattoridai 2 (Japan), where novice knappers seemed to be present in flint procurement camps, the less skilled knappers used round obsidian cobbles while skilled knappers used angular and sub-angular obsidian cobbles (Takakura 2013). At two late Mesolithic sites in Ireland, skill levels including beginners, novices and experts are identifiable in the exploitation of greenstone and volcanic tuffs, which are difficult materials to work (Sternke 2011). However, poor quality raw material may confound the record, as it could either represent provisioning of poorer materials for learning purposes but it may also influence production by skilled knappers (e.g. Taylor et al. 2018 p. 260; see also comment by Eren and Bebber in Castañeda 2018).

\subsection{Children making marks, art and tracks}

Although early cave art studies tended to focus on artistic perspectives, the discipline matured to consider associated archaeological and taphonomic contexts, and other traces of human activity such as footprints (e.g. Clottes 2009). Traditionally, Palaeolithic art was presumed to 
have been created by adult males engaging in hunting magic or shamanism (e.g. LewisWilliams 2009; Lewis-Williams et al. 1988). However, this perspective is not supported by the evidence (e.g. Adovasio et al. 2016; Cooney Williams and Janik 2018; Fritz et al. 2016). Females also likely participated regularly in big-game hunting amongst hunter-gatherers in the Americas (Haas et al. 2020) suggesting that we should be cautious about interpreting art related to hunting as also relating to male artists and/or learners. At least in Upper Palaeolithic Europe and Australia, children were also part of heterogeneous groups involved in cave exploration and cave art (Garcia et al. 1990; Romano et al. 2019), potentially sometimes on their own (Roveland 2000). In fact, finger flutings tentatively suggest that children and adolescents explored locations in caves that might have been inaccessible to adults (Bednarik 1986; Van Gelder 2015a). The focus on illuminating artists' identities has provided important evidence that art was a communal practice that included children (Cooney Williams and Janik 2018; Fritz et al. 2016; Van Gelder and Sharpe 2009). Evidence for children as makers of marks, art, and tracks can be found in Table 3.

\subsubsection{Art as education}

Children may have learned through the imitative act of recreating adult art, and while the youngest children may not have had the cognitive ability to understand the meaning behind the art or their own mark making, early participation would have served to embed cultural norms and meaning (Cooney 2018). Mithen (1988) and Guthrie (2005) both suggest that art depicting animals and animal traces can be understood as functional, with humans using caves as educational spaces to connect with and teach about the natural world. For example, depictions of animals, and of animal tracks and marks, may have taught animal behaviours and environmental details (Mithen 1988, p. 322), as well as teaching metacognitive skills. Guthrie (2005) similarly suggested that Palaeolithic art depicting animals functioned as educational tools for passing on hunting knowledge. Azéma and Rivère (2012) explore the possibility that parietal art depicting movement in a series of sequential images is a precedent to cinematic techniques, and also suggest that viewing parietal art could have been educational.

\subsubsection{Finger flutings, hand prints and hand stencils}

Some parietal art may have been the work of children, including lines made by fingers on soft surfaces variously called 'finger flutings', 'macaronis', 'serpentines' and 'meanders'; prints and stencils of hands, fingers, or other body parts; and tectiforms which are geometric forms involving an upward pointing roof or arrow (e.g. Bednarik 1986; Bednarik 2008; Cooney 2018; Cooney Williams and Janik 2018; Groenen 1988; Van Gelder and Sharpe 2009). Hallam (1971) recorded and analysed markings in Orchestra Shell Cave and Ross's Cave (both Western Australia), Kintore and Cutta Cutta caves (Northern Territory, Australia) and Koonalda Cave (South Australia) with the aim of determining whether they were natural or anthropogenic. Her analysis was primarily descriptive, but also included simple quantitative methods such as measuring the widths of grooves and the spaces between them. In Orchestra Shell Cave, markings look like they were most likely made with a tool, although Hallam (1971) does not rule out the possibility that juvenile hands created them using fingernails. She concludes that marks in Ross's Cave were probably made by children (Hallam 1971). Similarly, Bednarik (1986) discusses finger flutings in a number of Australian and French cave sites, and although his analysis is primarily descriptive, he attempts to connect mark morphometrics with age. With examples of juvenile finger flutings at Australian and European sites, he suggests that less accessible locations in caves were perhaps utilised by 'reckless' youths who were adventurous and agile (Bednarik 1986, pp. 48-49; 2008). Usually discovered in cave settings only, one case of finger fluting has been found at an open-air site. Crescentshaped markings alongside footprints in the Willandra Lakes (New South Wales, Australia), dated to the Last Glacial Maximum, are interpreted as finger markings made by children 
(Franklin and Hagbood 2009). In this case, Indigenous perspectives added to the methodological interpretations of this site, pointing out that in addition to the finger markings and footprints, there are also marks from spears (Franklin and Hagbood 2009).

Improvements in methodologies, including experimental research and comparative morphometrics, have allowed researchers to build on proposals that children made finger flutings. Sharpe and Van Gelder developed empirical approaches to connect biological markers of fingertips with ages and biological sex of the mark-makers (Sharpe and Van Gelder 2004, 2006; Van Gelder 2015a, 2015b; Van Gelder and Sharpe 2009). Specifically, sexual dimorphism in the ratio of ring and index fingers can help identify biological sex, while hand and finger tip measurements provide age ranges (Cooney Williams and Janik 2018 and references therein). Upper Palaeolithic finger flutings in caves located in France and Spain appear to have been made by both male and female adults and children as young as two years of age, with two fluters being girls of about 5 years old (Sharpe and Van Gelder 2004, 2006; Van Gelder 2015b; Van Gelder and Sharpe 2009). In addition, Van Gelder (2015b) argues that children may have been involved in making figurative art, potentially while learning to make parietal art. Van Gelder (2015a) confirmed that children younger than five years old were involved in making parietal markings in Koonalda Cave (South Australia), dated to ca. $20,000 \mathrm{BP}$, and argues that generally children were participating in mark making as part of wider groups. However, a particular location in the cave called 'The Squeeze' may have been difficult for adults to access, and marks there may indicate forays by children on their own.

Cooney Williams and Janik (2018) applied Sharpe and Van Gelder's methodologies in a series of Franco-Cantabrian Upper Palaeolithic cave sites, further demonstrating engagement by both women and children in the creation of parietal markings (Fig. 5). A standout finding is that the Upper Palaeolithic tectiforms drawn in Rouffignac Cave (France), which Guthrie (2005) had interpreted as representing vulva, were executed by females, including girls (Cooney Williams and Janik 2018). They cogently argue that there were not likely to have been restrictions on the identity of Palaeolithic artists: flutings throughout caves were created by women and children, including girls, showing that these were activities practiced by communities.

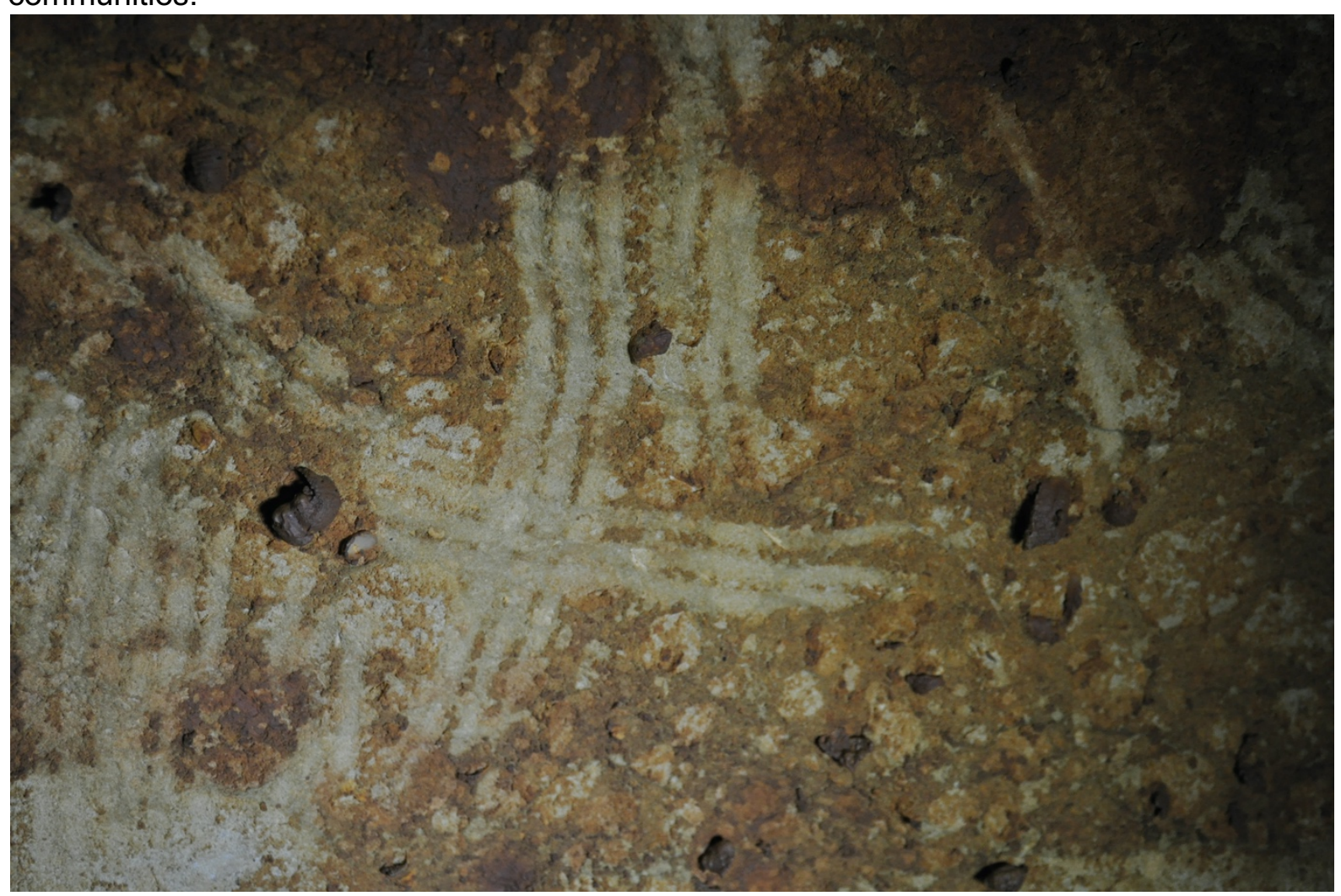


Figure 5. Finger flutings in Rouffignac cave (France), made by a child. Photo courtesy of Jessica Cooney Williams. Copyright: Jessica Cooney Williams.

Handprints and hand stencils on cave walls, a phenomenon evidenced on multiple continents also hold biological markers that help better identify the individuals who made the art (e.g. Guthrie 2005; Snow 2006; Snow 2013; Cooney Williams and Janik 2018; Onetto and Podestá 2011). Methdologies exploring the morphometrics of handprints and hand stencils and how they relate to age and sex have been developed and refined over the last few decades to distinguish between male and female hands, and adult and juvenile hands (e.g. Guthrie 2005; Snow 2006; Snow 2013). In Gargas and Tibiron caves (France) handprints were compared with experimental examples and were found to have been made by both sexes, with ages ranging from infancy through to adulthood (Groenen 1988). For one handprint in Gargas, the infant's hand was held by an adult in order to stencil it, accidentally including their own wrist in the process (Nowell 2015a and references therein). At the Spanish caves of El Castillo and La Garma, morphometric analyses of Palaeolithic handprints also show potential evidence of juvenile involvement (Pettitt et al. 2014).

\subsubsection{Mobiliary art}

Mobiliary art including plaques, engravings, bone discs, personal ornaments and figurines are connected in the literature to children and/or learners. Bednarik (2002) describes plaques from German Upper Palaeolithic sites of Hohle Fels, Kleine Scheuer and Obere Klause that are imprinted with paint stamped on using finger tips. These were subsequently compared with experimental fingertip mark making, and were determined to have most likely been made by children between six and 12 years of age (Bednarik 2008). We previously discussed various methods that have been developed over many decades to identify learners in stone tool contexts. Methods developed for the identification of inexperienced artists learning complex skills are less developed (Fritz et al. 2016), but there have been recent advances in microanalytical approaches. Olivia Rivero has analysed engravings dating to the Magdalenian from Franco-Cantabrian sites (Fig. 6; Rivero 2011, 2016, 2018). Rivero's multifaceted approach includes experimental replications (Fig. 7), followed by comparative microanalyses of the experimental reference sample with a large sample of artefacts (Rivero 2018; Rivero \& Garate 2020). The results point to a number of indicators for novice engravers including:

- failure to follow the primary groove when deepening incisions

- difficulty creating curved lines

- poor control of the force applied

- failure to control the orientation of the working part of the engraving tool

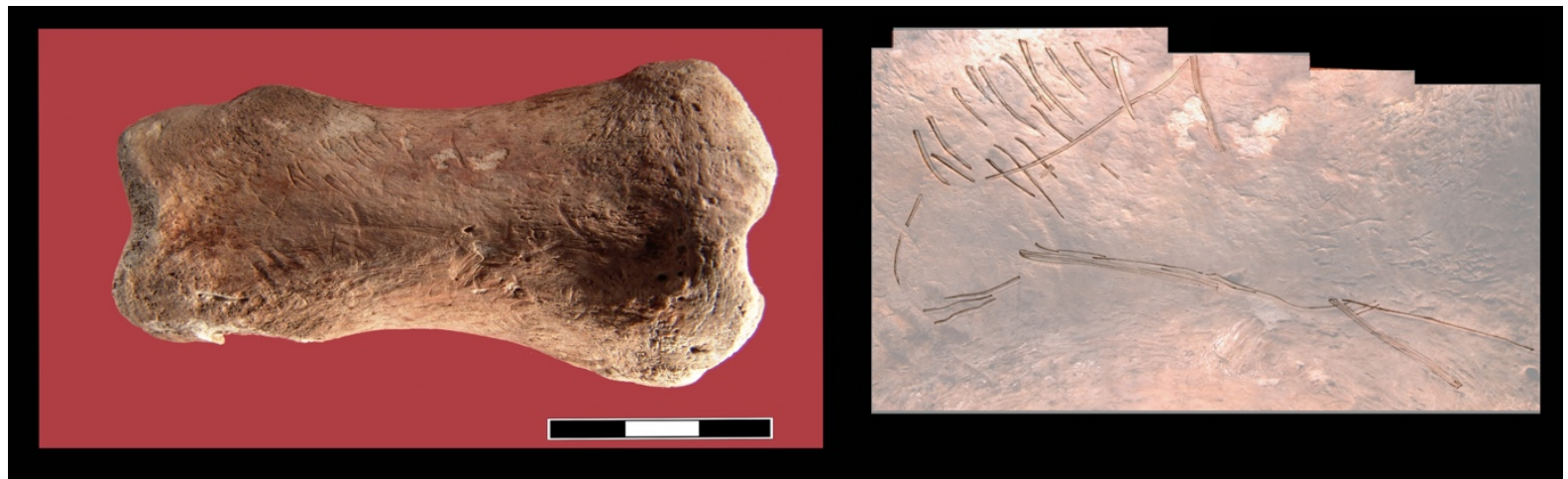

Figure 6. Engraving of a horse from the Magdalenian site of Las Caldas. The depiction of a horse is clearly executed by an inexperienced engraver showing failure to follow the primary groove, and difficulty creating curved lines. Image courtesy of Olivia Rivero. Copyright: Olivia Rivero. 


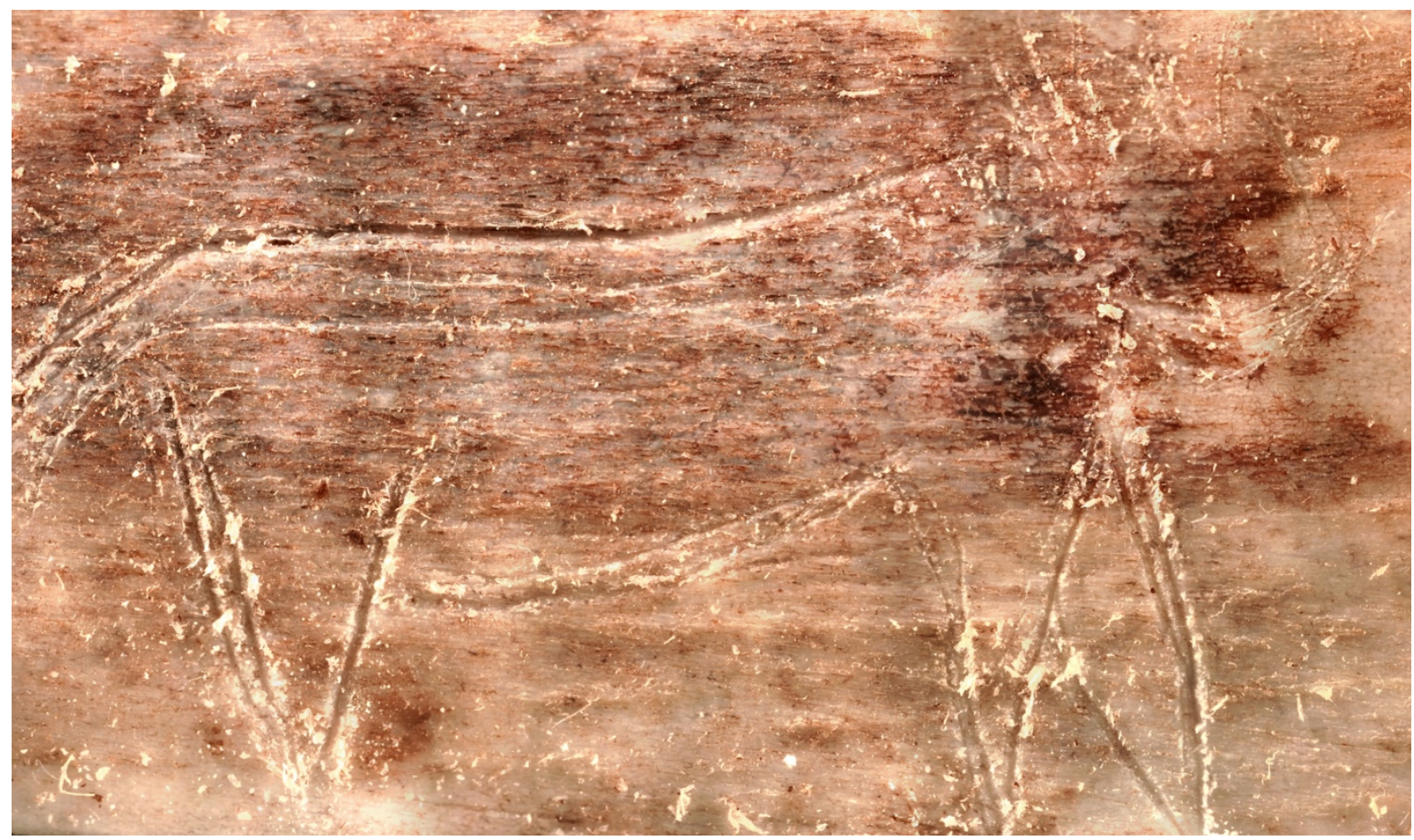

Figure 7. Experimental engraving of a horse on bone by an inexperienced engraver, showing many of the same errors seen archaeologically. Photo courtesy of Olivia Rivero (see also Rivero \& Garate 2020). Copyright: Olivia Rivero.

In contrast, experienced engravers not only demonstrate sophisticated aesthetics in producing their work such as execution of reliefs, but also excellent control resulting in few accidents (Rivero 2016, 2018). On the basis of a large-scale analysis and application of statistical methods, Rivero classifies engravers as novice, apprentice or expert, with apprentices demonstrating mixed characteristics. A pattern of raw material exploitation also emerges, with novices and experts utilising different qualities of materials (Rivero 2016), and an intriguing trend suggesting that beginners tend to focus on depicting horses while experts executed a range of figures (Rivero 2011).

Langley (2018) describes Upper Palaeolithic carved figurines, including a bear/bison head and a lion, that bear significant traces of polish. The polish, she reasons, could represent excessive handling by children who lived in a society in which beautiful objects were communally shared (Langley 2018). They need not have been initially designed as toys, as they could have entered a final phase as such prior to discard. Similarly, Nowell (2015b) discusses three dimensional figurines, such as those from Aurignacian sites in Germany's Swabian Jura, as objects that would enable children in a society to engage in metaphorical thinking. Langley and Litster (2018) also discuss Upper Palaeolithic figurines as potential material culture of children. Riede et al. (2018) further propose that these could have served alongside parietal art as objects serving to educate children about animal behaviour. We note that although we have included such objects under our section pertaining to 'art', a reframing of them as objects made for children would also make them suitable for discussion in the section about playthings.

Archaeological personal ornaments were also associated with hunter-gatherer children. These are typically known from burial contexts and include engraved bone and ivory discs, arm bands, beads and pendants (e.g. Sieveking 1971; Trinkaus and Buzhilova 2018; Vanhaeren and d'Errico 2001, 2003). Analyses of some personal ornaments from Upper Palaeolithic burials of children at La Madeleine (France) and Grotte des Enfants (Italy) show that associated shells were likely attached to clothing worn by the children in life (Vanhaeren and 
d'Errico 2001, 2003). Comparative analysis showed that the shells were either chosen for their small size or worked in such a way as to reduce their size, adapting them to be suitable for child-sized bodies.

\subsubsection{Footprints}

Footprints of $H$. sapiens children in cave contexts have long been recognised, particularly in relation to proposals that the presence of children in caves represents initiation rites (see Cooney 2018; Roveland 2000 for reviews). In Réseau Clastres cave (France), footprints dated to the Magdalenian show a group of people who were likely walking together (Garcia et al. 1990). The group consisted of three children, plus either a male and female adult, or possibly a male adult and an adolescent. According to Garcia et al. (1990), during their spelunking, two of the group members, probably the youngest child and the woman/adolescent, stayed behind at one point by a stream, while the other three went on ahead, later returning before all exited the cave. At Bàsura Cave (Italy) 180 human footprints dated to ca. 12,340 BP, underwent a multidisciplinary analysis (Romano et al. 2019). Like at Réseau Clastres, the results from Bàsura Cave show a group of five individuals of mixed ages and sexes, including two adults, an adolescent and two children, the youngest of which was around 3 years of age. The authors show the group used the cave for multiple activities, including making fires, playing with clay, kneeling and crawling through a small space (Romano et al. 2019). The authors suggest that this single episode of exploration of a deep cave with poor lighting was potentially dangerous, but also involved playful activities, with one of the children manipulating clay. Footprints in Tuc d'Audoubert (France) dated to ca. 16,000 calBP show that a child of around three or four years old was present at the entrance to the chamber where a clay bison was manufactured (Bégouën et al. 2009; Fritz et al. 2016). In a review paper, Fritz and colleagues (2016) propose that this child played a role in the making of the sculpture. Together these analyses show the inclusion of very young children in cave exploration.

In addition, the presence of children's footprints at open-air sites, while less common, is documented at Monte Hermoso 1, along Argentina's Atlantic coast (Bayón and Politis 1996; Bayón et al. 2011), Willandra Lakes, Australia (Webb et al. 2006), and in White Sands National Park, New Mexico, USA (Bennett et al. 2020). At Monte Hermoso 1, hunter-gatherer children, youths and women left hundreds of footprints along the shore of a pond, likely while gathering plants and bird eggs. These footprints clearly show children participating in foraging trips with women and older children between 7,920 and 6,600 years ${ }^{14} \mathrm{C}$ BP (Bayón et al. 2011). At Willandra Lakes, researchers estimated that a group of at least 8 individuals created the footprints in hardpan along a shoreline between around 19,000 and 23,000 years ago. Amongst them were children and adolescents, some of whom may have also created finger flutings (Webb et al. 2006; Franklin and Hagbood 2009). In New Mexico, a single woman or young adult man left a trackway of footprints 1.5 kilometres long directly across a mudflat (Bennett et al. 2020). Periodically, this person set down a child under the age of two, but largely they carried the child while moving swiftly and purposefully. Just a few hours later, likely the same person returned along his or her former tracks, this time without the child. In the meantime, a giant sloth and a mammoth had crossed the person's first trackway, indicating that these tracks are at least 10,000 years old. While the purpose of this traveller is unclear, it appears that an important component of their journey was the swift, efficient transport of the child (Bennett et al. 2020).

\section{Discussion}

Our review included three broad categories related to hunter-gatherer children's material culture in the past: children's toys and tools, children knapping stone, and children making art, marks and tracks. The last few decades have seen the establishment of robust systematic and scientific methods to identify children (contra Lillehammer 2008). As a result, new frameworks have been developed that extend beyond merely reporting children's presence to 
better understand their behaviours and contextualise them within societies. In what follows, we outline our main findings regarding similarities and variation in hunter-gatherer children's material contributions in the deep past. Specifically, we focus on children's learning, agency, minds and bodies, use of space, and embeddedness in their social worlds.

\subsection{Children as learners}

In as much as teaching and learning in hunter-gatherer societies can be inferred from the archaeological record, this review shows variability in these processes (e.g. Wild 2020; Wilkins 2020). Children appear to have learned through play in the past, as they do in the present (Cooney 2018). Children's playthings are often objects that served as learning tools, such as miniature weaponry. Children also interacted with materials that they would go on to expertly manipulate and transform later in life, such as flint and clay. As opposed to Ferguson's (2008) suggestion that children would have had limited access to flintknapping processes, debitage, and tools because they would be dangerous, we suggest the contrary based on cross-cultural studies showing that children have access from very young ages to 'dangerous' tools including sharp objects such as knives (Lancy 2016). And yet, it is archaeologically unclear at what ages and/or developmental stages children engaged with lithic materials in the different sites where this has been suggested, and how this relates to motor skills, attention span, or cognitive frameworks such as spatial abilities and mental abstraction (see also Finlay 2015). Going forward, experimental studies and perspectives, including from contemporary societies with experience knapping stone (e.g. Roux and David 2005), could shed light on this topic.

Learning processes have been correlated with both cultural norms and cultural evolutionary processes. Some suggest that within highly standardised lithic traditions, variability indicates the presence of inexpert knappers (Audouze and Cattin 2011; Baxter 2008). Others make the case that causes of variability are complex (Ferguson 2008; Eren et al. 2011) and may not only represent errors associated with skill level. In highly standardised production traditions, mistakes could represent complex production techniques and/or greater challenges in learning how to reproduce tools (Klaric 2018), with confounding issues regarding raw materials (Högberg and Larsson 2011; Langlais 2018).

Research shows that collaborative horizontal learning, i.e. learning that takes place with and from other children, is particularly important in many small-scale societies, including extant hunter-gatherer societies (Van Gelder 2015a). This may also have been the case in some hunter-gatherer societies in the past. Archaeologists have proposed that spatially distinct areas where novice flint knappers appear to have worked away from experienced knappers may indicate that hunter-gatherer children in the past were knapping in peer groups (e.g. Grimm 2000; Pigeot 1990; Takakura 2013). An intriguing example even suggests that at the Upper Palaeolithic site of Verberie (France), less advanced learners were situated closer to experts, while apprentices were more spread out (Audouze and Janny 2009). This may point to greater autonomy afforded to adolescents, or to different types of learning such as experimentation or instruction from peers. Learning more complex skills may involve additional verbal instruction and/or demonstration from experts, such as 'academic cores' and expert reduction with all products left in the assemblage, and we outlined examples from the lithic record that are interpreted as such (e.g. Bodu et al. 1990; Cunnar 2015; Fischer 1990b, 1990a; Karlin et al. 1993; Lombard 2015; Takakura 2013).

Beyond learning to create stone tools and art, hunter-gatherer children in the past would have needed to learn to make and manage fires, hunt and forage for terrestrial and aquatic prey, butcher and skin animals, forage for plant foods, honey and medicines, prepare and cook foods, understand seasonal patterns and landscape use, understand social dynamics and kin relations, spirituality, oral traditions, music, dance and much more. Many of these domains, especially those related to intangible culture, may leave few direct archaeological traces, which in turn makes the identification of children's engagement with such domains highly 
challenging. While this is also true of adult material culture, we must be mindful of the presence of children as we develop methodologies that are aimed at better understanding these aspects of culture in the archaeological past.

We suggest three examples that could shed further light on children learning subsistence skills, including learning to hunt, butcher and forage. Frison (1970a, 1970b) argued that the use of smaller weapons at a site could indicate the exploitation of smaller prey. Similarly, although they do not make a direct connection between these functions in their paper, Park and Mousseau (2003) argue that small Dorset harpoon heads could have been made to match smaller prey, and also as functional hunting tools for children. We propose that these can both be true, with smaller functional hunting tools used by children to hunt smaller prey, something which is seen ethnographically and has been proposed for Middle Palaeolithic hominins as well (Crater Gershtein et al. 2020; Kuhn and Stiner 2006; Lombard 2015; Stiner et al. 2000). Relatedly, learning basic concepts of butchery could have taken place either communally on larger prey, or on smaller animal bodies that would be better suited to small fingers (Audouze and Janny 2009). At Lower Palaeolithic sites, butchery mark patterns have been analysed to highlight different skill levels that may help understand group dynamics (e.g. Rabinovich et al. 2008; Stiner et al. 2009). An experimental study of fish butchery also highlights identifiable differences in skill level (Willis and Boehm 2015). While not all of these examples relate to $H$. sapiens, as a methodological approach they could provide an avenue for identifying the involvement of novices at more recent archaeological sites. Accounting for seasonality, at sites where faunal assemblages have evidence of the exploitation of different prey sizes, cut mark analyses could potentially show differences in skill and by extension, juvenile involvement. Subsistence patterns relating to children may not only represent their learning skills in preparation for adult life, but also their life as juveniles who are self-provisioning in ways that are adapted to their physiology (Bliege Bird and Bird 2002; Crittenden 2016). In other words, children's own goals, and adult goals for them, are not always learning-oriented. Zooarchaeologists should continue to consider the potential contribution by children to hunting and foraging activities, particularly with respect to small prey and foraging for shellfish (e.g. Audouze and Janny 2009; Stiner et al. 2000; Politis 2007).

\subsection{Children's agency}

Human children have longer childhoods than other primates, and this life history pattern increases their opportunities to play and experiment (Kamp 2015; Nowell 2015b, 2015a; Nowell and White 2010). Considering hunter-gatherer children and adolescents as primary innovators or spreaders of innovation in an archaeological context is an emerging research trend (Langley and Litster 2018; Lew-Levy, Milks, et al. 2020; Nowell 2015b, 2015a; Nowell and French 2020; Riede et al. 2018; Wilkins 2020; Sterelny 2021). Researchers have consistently demonstrated that children have agency, and are modifiers of things, places and societies. Yet, a perceived lack of agency in childhood has likely contributed to researchers neglecting to study them in the past (Nowell 2021, p. 164). Children often act independently and do not merely imitate adults (Lillehammer 2010a; Roveland 2000). An examination of the location and use of toys and small tools covered in this review may reflect the autonomy afforded to children, providing opportunities to explore and learn how to use technologies and develop mental abstraction away from adult instruction or intervention. For example, at Thule sites (Greenland) the placement of playhouses as far as 200 metres away from the main settlements (Hardenberg 2010) may show evidence for autonomous play and exploration, as afforded in middle childhood in many extant hunter-gatherer communities. These play areas were set on plateaus overlooking settlements, likely giving views by adults of children playing there and vice versa, and suggests that children used these spaces independently (Hardenberg 2010). The placement of playhouses at some distance from the main camp is also evidenced amongst contemporary Dukha reindeer herders (Figure 1; Mackie et al. 2015). Langley (2020) proposes that certain areas at the Magdalenian site of Étiolles, which may 
have functioned as children's play spaces could be deliberately situated out of sight of adults, creating 'secret' spaces.

During play and experimentation, children can be innovative by modifying what is already there, and by creating something entirely new (Nowell and White 2010). Ethnographic research also suggests that children retain technologies abandoned by adults. For example, while San adult spear hunting has been diminished, San children continue to enact spear hunting in their play (Imamura 2016). Such activities not only represent a "collective memory" but may also "store and revive" traditional activities (Imamura 2016, p. 184). In sum, by creating worlds distinct from those of adults, children retain and create knowledge which may drive both cultural innovation and change (Lillehammer 2010b; Reckin et al. 2020). That said, it is important to note that different periods in the past experienced different rates of innovation or cultural stability. How socialisation practices and opportunities for autonomous exploration and play may have contributed to the acceleration or deceleration of technological and behavioural change is an important avenue for future research (Riede et al. 2018).

\subsection{Children's minds and bodies}

The minds of and bodies of children are not simply those of scaled-down underdeveloped adults (Ferguson 2008; Gamble 1999; Mithen 1995, p. 311), but are adapted to their present needs. Children who may not be cognitively able to understand the meaning behind material culture can still observe, participate socially, imitate, and be playful (Bednarik 2008; Cooney 2018; Cooney Williams and Janik 2018). 'Art' is a relatively well-explored mechanism through which children likely learned to connect objects with meaning, and provides useful opportunities to explore questions about young minds in the past (Langley and Litster 2018). Children's physical bodies would also have influenced their behaviour, play, and learning (e.g. Audouze and Janny 2009). First, certain motor skills are required before they are capable of, for example, knapping stone. Exactly at what age and stage the youngest children would have played and explored with such an essential material remains unclear. Toys like the ball found with a child burial (Argentina) dated to ca. 6400 BP (Politis 1998) may reflect the development of gross motor skills like throwing, while learning to craft detailed Magdalenian engravings would have required the ability to develop precision motor skills (Rivero 2016, 2018). We see examples where younger children were potentially limited by their physique, reflected in smallsized weapons adapted for their body size and strength; some of these are deemed too small to be functional and were likely for work-themed play, while others may show a progression towards active hunting participation in middle childhood and adolescence (e.g. Kenyon and Arnold 1985; Losey and Hull 2019). Hardenberg (2010) also hypothesized that children's bodies may have influenced their selection of small sized stones in constructing their play areas (Hardenberg 2010; see also Mackie et al. 2015). However, their smaller bodies may also have been advantageous at times, allowing them to potentially explore spaces and places that would have been difficult to access by adults (Bednarik 1986; Van Gelder 2015a).

\subsection{Children's use of space}

Childhood is socially and spatially shared with adults (Lillehammer 2010a). Children did not just alter the space and settlements they inhabited (Hammond and Hammond 1981), they were instrumental in the spatial organisation of many sites by affecting where adults undertook particular activities (Roveland 2000). A full integration of children into the adult world and material culture can be constrained, for example, by a lack of availability of quality raw materials, or by the aforementioned physiological or cognitive differences between children and adult bodies and minds. This could result in an absence of younger learners at specialised task sites. However, there are certainly archaeological examples in this review that point to the presence of children interacting with adults away from residential camps, for example at resource-gathering locations (Bayón et al. 2011), hunting sites, and knapping workshops (e.g. Frison 1970a, 1970b; Milne 2005). Proximity of sites to good raw material sources may 
improve the visibility of children in flint knapping contexts in particular, because there could have been less concern about the large amount of waste created while learning to knap (e.g. Bamforth and Finlay 2008). Some workshop sites may represent persistent places used by learners whose skills matured in that space over time, leaving their own archaeological signature of growth and development (Finlay 2015). Other locations, clearly showing interaction between children and adults through art and footprints in cave contexts, also help us better understand the integration of children in societies (e.g. Romano et al. 2019; Roveland 2000). A particularly important observation is the finding that women and girls were also taking part in artistic activities, meaning these were inclusive spaces (Cooney Williams and Janik 2018; Van Gelder and Sharpe 2009). Given that in the deeper past often represent a palimpsest of activities, and the mobility of many hunter-gatherers results in ephemeral occupations, the identification of distinct areas utilised by children may be an archaeological rarity (Shea 2006).

\subsection{Embedding children in social worlds}

The findings presented in this review suggest that hunter-gatherer children were integrated into the social worlds of their communities from an early age (see also Baxter 2008). Group cave exploration and involvement in parietal art may have variously consisted of small groups and larger groups (e.g. Garcia et al. 1990; Romano et al. 2019; Van Gelder and Sharpe 2009). Childhood learning, and in particular participation in Palaeolithic art, has been described as resulting from 'communities of practice' (Cooney 2018; Cooney Williams and Janik 2018; Langley 2018; Nowell 2015a, 2015b), defined as a 'network of relations among people and objects mediated by actions they conduct [...] and continuing over time' (Joyce 2012, p. 150). In some cases, children may have been afforded special status (e.g. Petersen et al. 2015; Trinkaus and Buzhilova 2018; Vanhaeren and d'Errico 2001) but this is not universal. Child and adolescent burials variably point to some societies treating children as undifferentiated 'full members' who were integrated into their communities (Cooney 2018) while in others they may have been assigned a special status on the basis of their age, gender, or social stratification.

As others have discussed (e.g. Finlay 1997, 2008; Fritz et al. 2016; Gero 1991), analyses and interpretations of the evidence for children have often been gendered, and this extends to our understanding of gender in the past. For example, some male lead authors either assumed or explicitly argued that lithics attributed to children would have been primarily or exclusively related to play, learning and/or activities of boys (e.g. Bodu et al. 1990; Fischer 1990b; Frison $1970 b)$, and this extends to interpretations of Neanderthal societies (Stapert 2007). However, there are notable exceptions to this such as Elliott (2009) who argues that hunting by Mesolithic societies at Star Carr could well have been a non-gendered practice.

In contrast, female lead authors appear less likely to extrapolate presumed sex and/or gender roles onto material culture attributed to children in the past, and appear more likely to either use non-gendered language in relation to evidence of child knappers such as 'they', 'children' and 'youths' (e.g. Pigeot 1990; Grimm 2000; Audouze and Cattin 2011; but see Karlin et al. 1993 , p. 331), and/or explicitly propose that child knappers could have comprised both genders with use of inclusive pronouns such as 'his or her' (Pigeot 1990, p. 137; Sternke and Sørensen 2009, p. 720; Sternke 2011, p. 224). Others touch on the difficulties of gendering activities and activity areas (e.g. Cattin 2010). Whilst gendering may create more nuanced identities for children in the past, archaeologists cannot identify gender through either biological sex or behaviours. For example, even if stone tool manufacture is recorded as a predominantly male activity ethnographically (see discussion in Stapert 2007), we should be careful to extrapolate either gendered or sexual division of labour from the archaeological stone tool record on the basis of ethnography alone (e.g. see Haas et al. 2020). This is especially true in relation to children: adult norms applied to adults do not always map onto 
children (e.g. Park 1998), especially considering the autonomy noted in many contemporary hunter-gatherer societies.

\section{Conclusion and Future Directions}

This review demonstrates that 'childhood' in the past, as in the present, would have been variably experienced (Kamp 2015). Cross-disciplinary research cannot provide clear and straightforward answers, of course, but it can expand our thinking about childhood and offer insightful perspectives (Schwartzman 2006). As an example, a recent review by Langley and Litster (2018) looked at childhood play in recent and contemporary hunter-gatherer groups, and proposed a wide array of additional, and rarely-considered, aspects of children's material culture. These possibilities include musical instruments, games, pigments, discarded and broken adult objects, collections of natural objects and presence of manuports, and evidence of small-sized and baby animals, all of which demonstrate the wide range of interpretative possibilities which should be considered in archaeological research.

Despite the impressive array of questions asked, the archaeology of hunter-gatherer children feels transient and fragmented, while identification of children and their activities in the archaeological record remains uneven. This is partly because formation processes may affect what evidence pertaining to children survives. First, some materials preserve better than others and in some cultures children's toys may have been crafted from perishable materials such as wood, which is relatively easy to work but rarely preserves in the archaeological record (Hurcombe 2007; Park 2006; Sternke and Sørensen 2009; but see Riede et al. 2018). Certain technologies involve long operational sequences from sourcing materials through to final discard; knapping stone, for which such sequences can both preserve and be identified in part or in entirety, may allow better identification of learning processes (Sternke and Sørensen 2009). Second, the stratigraphic integrity of a site affects the identification of human activity spatially and temporally. The type of site (e.g. caves, open-air sites) and activity taking place there (e.g., task-specific sites, residential sites) can affect both the formation of an archaeological signature of children and its preservation (Audouze and Janny 2009). Finally, some authors argue the site type may have influenced the presence/absence of children and/or the activities they undertook there (e.g. Bamforth and Hicks 2008; Dawe 1997; Langlais 2018). When the archaeological record is well preserved and provides relatively high resolution of the chaîne opératoire, it allows researchers to identify patterns, including the standardisation of technologies which, in turn, can help distinguish differences in skill levels (Langlais 2018; Simonet 2009; see also Audouze and Karlin 2017). As a result, some children's activities may be better preserved than others. Going forward, a key research question around children's material culture should focus on whether it more frequently consists of materials that are less likely to preserve and whether there is a differentiation between children's play objects and functional tools.

Further, new methodological approaches are needed to distinguish children's material contributions from those of adults (see also Nowell 2021, p.128). Experimental archaeology involving children has a significant role to play going forward. Ferguson (2008) argues that children's bodies and minds are not the same as those of an adult 'novice'. Children explore materials and objects in different ways, and this can potentially result in innovative ways of doing things. For example, experimental studies with children have found them to independently 'innovate' bipolar reduction techniques while attempting to knap stone (Ferguson 2008; Sternke and Sørensen 2009). Experiments involving groups of different ages and abilities may also help us better understand how children fit into the fabric of huntergatherer societies, and account for the social features of learning and limitations due to underdeveloped motor skills or strength (e.g. Finlay 2008; Rich et al. 2016).

The further development of methodologies that help identify children beyond tool and art production will facilitate future intensive studies on children and learners, and therefore more 
well-rounded studies of past cultures as a whole. Although a new methodology to identify children's play areas is applied in a recent paper to mixed-subsistence groups (Cory 2021), such an approach would also be applicable to sites attributed to hunter-gatherer groups. While we do not advocate that all archaeologists should turn their focus to researching childhood, we encourage archaeologists to consider that the agency of children and their ongoing process of learning and enculturation shape every aspect of adult life, as well (e.g. Derricourt 2018; Sofaer 2000). We hope that this review may encourage archaeologists to be more aware and open to the possibilities brought by studying children's activities and material culture, and bridge the gap between theoretical engagement and a practice of expecting the presence of children in the archaeological record (Lillehammer 2010a; Lillehammer 2015). The majority of publications included in this review (85\%) pertained to sites located in Europe and North America. Therefore, we hope for further research that focuses on identifying evidence of children from sites in Asia, Australia and Africa as this will facilitate a more representative identification of patterns and variability of past hunter-gatherer childhoods. Many of the themes explored in this review can likely also be identified in archaeological contexts attributed to other species of Homo, which will further enable interspecies comparisons. As powerful as the lithic record has been in bringing children of the past to the forefront of analyses, children are far more than just mistake-makers. We should continue to seek evidence of their learning, play and innovation in the archaeological record.

TABLE 1 Evidence for Children's Playthings and Tools

\begin{tabular}{|c|c|c|c|c|c|}
\hline $\begin{array}{l}\text { Period } \\
\text { and/or } \\
\text { date(s)* }\end{array}$ & Culture & $\begin{array}{l}\text { Site(s) } \\
\text { and/or } \\
\text { Region }\end{array}$ & Material & $\begin{array}{l}\text { How Identified } \\
\text { as Evidence of } \\
\text { Children }\end{array}$ & Reference \\
\hline $\begin{array}{l}\text { Late } \\
\text { Prehistoric }\end{array}$ & $\begin{array}{l}\text { Northwestern } \\
\text { Plains }\end{array}$ & $\begin{array}{l}\text { Head- } \\
\text { Smashed-In } \\
\text { Buffalo } \\
\text { Jump, } \\
\text { Alberta } \\
\text { (Canada) }\end{array}$ & $\begin{array}{l}\text { Small, } \\
\text { poorly } \\
\text { made } \\
\text { projectile } \\
\text { points, } \\
\text { small shaft } \\
\text { smoother. }\end{array}$ & $\begin{array}{l}\text { Comparing } \\
\text { projectile point } \\
\text { assemblage } \\
\text { with } \\
\text { archaeological } \\
\text { and } \\
\text { ethnographic } \\
\text { point samples. }\end{array}$ & Dawe 1997 \\
\hline $\begin{array}{l}\text { Early } \\
\text { Paleoindian }\end{array}$ & Paleoindian & $\begin{array}{l}\text { Parkhill site, } \\
\text { Lake Huron } \\
\text { (Canada) }\end{array}$ & $\begin{array}{l}\text { Miniature } \\
\text { stone tools } \\
\text { (points, end } \\
\text { scraper). }\end{array}$ & $\begin{array}{l}\text { Argues against } \\
\text { being attributed } \\
\text { to children, } \\
\text { instead as } \\
\text { ideotechnic on } \\
\text { basis of lack of } \\
\text { signs of use. }\end{array}$ & Ellis 1994 \\
\hline $\begin{array}{l}\text { From 9385- } \\
9260 \text { cal BC } \\
\text { to ca. } 8555- \\
8380 \mathrm{cal} \mathrm{BC}\end{array}$ & $\begin{array}{l}\text { Early } \\
\text { Mesolithic }\end{array}$ & $\begin{array}{l}\text { Star Carr, } \\
\text { North } \\
\text { Yorkshire } \\
\text { (U.K.) }\end{array}$ & $\begin{array}{l}\text { Small } \\
\text { barbed } \\
\text { antler } \\
\text { points. }\end{array}$ & $\begin{array}{l}\text { Suggests the } \\
\text { smaller barbed } \\
\text { points from Star } \\
\text { Carr may have } \\
\text { been functional } \\
\text { weaponry for } \\
\text { children, and } \\
\text { raw material } \\
\text { sourcing may } \\
\text { have also been } \\
\text { undertaken by } \\
\text { children. }\end{array}$ & $\begin{array}{l}\text { Elliott } \\
2009 ; \\
\text { Milner et } \\
\text { al. } 2018\end{array}$ \\
\hline
\end{tabular}




\begin{tabular}{|c|c|c|c|c|c|}
\hline $\begin{array}{l}\text { Late } \\
\text { Prehistoric, } \\
\text { ca. } 1033 \text { AD }\end{array}$ & $\begin{array}{l}\text { Late } \\
\text { Prehistoric }\end{array}$ & $\begin{array}{l}\text { Kobold Bison } \\
\text { Jump, Level } \\
\text { IV, Montana } \\
\text { (USA) }\end{array}$ & $\begin{array}{l}\text { Small, } \\
\text { nondescript } \\
\text { projectile } \\
\text { points. }\end{array}$ & $\begin{array}{l}\text { Descriptive } \\
\text { comparison of } \\
\text { projectile points. }\end{array}$ & $\begin{array}{l}\text { Frison } \\
1970 a\end{array}$ \\
\hline $\begin{array}{l}\text { Late } \\
\text { Prehistoric, } \\
\text { radiocarbon } \\
\text { dates: } 201 \\
\pm 100(A D \\
1740) \\
280 \pm 100 \text { (AD } \\
1670)\end{array}$ & $\begin{array}{l}\text { Late } \\
\text { Prehistoric }\end{array}$ & $\begin{array}{l}\text { Glenrock } \\
\text { Buffalo } \\
\text { Jump, } \\
\text { Wyoming } \\
\text { (USA) }\end{array}$ & $\begin{array}{l}\text { Anomalous, } \\
\text { small } \\
\text { projectile } \\
\text { points. }\end{array}$ & $\begin{array}{l}\text { Descriptive } \\
\text { comparison of } \\
\text { projectile points. }\end{array}$ & $\begin{array}{l}\text { Frison } \\
1970 b\end{array}$ \\
\hline $\begin{array}{l}\text { Ca. } 1400- \\
1800 \mathrm{AD}\end{array}$ & Thule & $\begin{array}{l}\text { Various sites, } \\
\text { Northeast } \\
\text { Greenland } \\
\text { (Denmark) }\end{array}$ & $\begin{array}{l}\text { Children's } \\
\text { playhouses }\end{array}$ & $\begin{array}{l}\text { Archaeological } \\
\text { survey to } \\
\text { identify potential } \\
\text { playhouses; } \\
\text { measures, } \\
\text { records and } \\
\text { describes } \\
\text { playhouses. }\end{array}$ & $\begin{array}{l}\text { Hardenber } \\
\text { g } 2010\end{array}$ \\
\hline $\begin{array}{l}\text { Ca. } 272-792 \\
\text { BC; earliest } \\
\text { radiocarbon } \\
\text { date from } \\
\text { cave } \\
\text { reported in } \\
\text { paper as } \\
2482 \pm 260 \\
B P, \text { so } \\
\text { Terminus } \\
\text { post quem }\end{array}$ & & $\begin{array}{l}\text { Lovelock } \\
\text { Cave, } \\
\text { Nevada } \\
\text { (USA) }\end{array}$ & Sling. & $\begin{array}{l}\text { Associated with } \\
\text { child burial, } \\
\text { placed around } \\
\text { the neck of the } \\
\text { child; } \\
\text { ethnographic } \\
\text { analogy. }\end{array}$ & $\begin{array}{l}\text { Heizer and } \\
\text { Johnson } \\
1952\end{array}$ \\
\hline N.D. & Early Thule & $\begin{array}{l}\text { Nelson River } \\
\text { site, Banks } \\
\text { Island } \\
\text { (Canada) }\end{array}$ & $\begin{array}{l}\text { Various } \\
\text { artefacts } \\
\text { interpreted } \\
\text { as toys } \\
\text { including } \\
\text { dolls } \\
\text { (human } \\
\text { figures), } \\
\text { miniature } \\
\text { harpoon } \\
\text { heads, dart } \\
\text { head, } \\
\text { harpoon } \\
\text { foreshaft, } \\
\text { bows, snow } \\
\text { knife, } \\
\text { wooden } \\
\text { points and } \\
\text { arrows, }\end{array}$ & $\begin{array}{l}\text { Small size, and } \\
\text { manufacture } \\
\text { from } \\
\text { 'unsuitable' } \\
\text { materials, e.g. } \\
\text { wood. }\end{array}$ & $\begin{array}{l}\text { Kenyon } \\
\text { and Arnold } \\
1985\end{array}$ \\
\hline
\end{tabular}




\begin{tabular}{|c|c|c|c|c|c|}
\hline & & & $\begin{array}{l}\text { miniature } \\
\text { sleds, } \\
\text { game. }\end{array}$ & & \\
\hline $\begin{array}{l}\text { Ca. } 21,000- \\
14,000 \mathrm{cal} \\
\mathrm{BP}\end{array}$ & Magdalenian & $\begin{array}{l}\text { Various } \\
\text { sites, } \\
\text { Western } \\
\text { Europe }\end{array}$ & $\begin{array}{l}\text { Antler tool, } \\
\text { poorly } \\
\text { reworked } \\
\text { osseous } \\
\text { points, } \\
\text { projectile } \\
\text { points } \\
\text { reworked } \\
\text { into } \\
\text { pendants, } \\
\text { figurines, } \\
\text { bone discs } \\
\text { (rondelles). }\end{array}$ & $\begin{array}{l}\text { Miniature size, } \\
\text { high levels of } \\
\text { polish, poor } \\
\text { quality of } \\
\text { manufacture or } \\
\text { alterations (e.g. } \\
\text { drilling holes for } \\
\text { suspension). }\end{array}$ & $\begin{array}{l}\text { Langley } \\
2018\end{array}$ \\
\hline $\begin{array}{l}13,160 \text { to } \\
12,800 \mathrm{BP}\end{array}$ & Magdalenian & $\begin{array}{l}\text { Étiolles } \\
\text { (Paris Basin) }\end{array}$ & Play areas. & $\begin{array}{l}\text { Particular tent } \\
\text { locations are of } \\
\text { overall smaller } \\
\text { size, smaller } \\
\text { hearth stones, } \\
\text { limited lithic } \\
\text { record, and } \\
\text { absence of } \\
\text { ochre and } \\
\text { ornaments. } \\
\text { Their location } \\
\text { out of sight of } \\
\text { larger tent } \\
\text { areas suggests } \\
\text { they may have } \\
\text { functioned as } \\
\text { 'secret spaces' } \\
\text { by children. }\end{array}$ & $\begin{array}{l}\text { Langley } \\
2020\end{array}$ \\
\hline $\begin{array}{l}19,000- \\
23,000 \text { uncal } \\
\text { years BP }\end{array}$ & $\begin{array}{l}\text { Mal'ta } \\
\text { Culture }\end{array}$ & $\begin{array}{l}\text { Mal'ta } \\
\text { (Siberia, } \\
\text { Russia) }\end{array}$ & $\begin{array}{l}\text { Anthropom } \\
\text { orphic and } \\
\text { animal } \\
\text { figurines } \\
\text { from the } \\
\text { site, and } \\
\text { grave } \\
\text { goods } \\
\text { associated } \\
\text { with child } \\
\text { burial may } \\
\text { have been } \\
\text { toys. }\end{array}$ & $\begin{array}{l}\text { Association of } \\
\text { objects with } \\
\text { child burial, } \\
\text { comparison with } \\
\text { ethnology and } \\
\text { naturalistic } \\
\text { depictions of } \\
\text { children in } \\
\text { figurines } \\
\text { informs us of } \\
\text { childhood, and } \\
\text { may have been } \\
\text { designed for } \\
\text { children to use. }\end{array}$ & $\begin{array}{l}\text { Lbova } \\
2021\end{array}$ \\
\hline $\begin{array}{l}\text { From ca. } \\
70,000-\end{array}$ & & $\begin{array}{l}\text { Various } \\
\text { (Southern }\end{array}$ & \begin{tabular}{|l} 
Complex \\
hunting
\end{tabular} & $\begin{array}{l}\text { Argues that } \\
\text { presence of }\end{array}$ & $\begin{array}{l}\text { Lombard } \\
2015\end{array}$ \\
\hline
\end{tabular}




\begin{tabular}{|c|c|c|c|c|c|}
\hline $\begin{array}{l}60,000 \text { BP } \\
\text { onwards }\end{array}$ & & Africa) & $\begin{array}{l}\text { technologie } \\
\text { s including } \\
\text { bows, } \\
\text { snares and } \\
\text { traps. }\end{array}$ & $\begin{array}{l}\text { complex } \\
\text { technologies } \\
\text { implies greater } \\
\text { involvement of } \\
\text { language in } \\
\text { teaching and } \\
\text { learning, uses } \\
\text { ethnographic } \\
\text { analogy. }\end{array}$ & \\
\hline $\begin{array}{l}\text { Ca. } 100-800 \\
\text { AD }\end{array}$ & & $\begin{array}{l}\text { Par-Tee site, } \\
\text { Oregon } \\
\text { (USA) }\end{array}$ & $\begin{array}{l}\text { Whalebone } \\
\text { atlatls as } \\
\text { functional } \\
\text { children's } \\
\text { tools. }\end{array}$ & $\begin{array}{l}\text { Range of sizes } \\
\text { of atlatls and } \\
\text { atlatl fragments, } \\
\text { sizes of adult } \\
\text { and children's } \\
\text { hands, and use } \\
\text { of whalebone } \\
\text { as a material. }\end{array}$ & $\begin{array}{l}\text { Losey and } \\
\text { Hull } 2019\end{array}$ \\
\hline $\begin{array}{l}\text { Various } \\
\text { dates from } \\
\text { Late } \\
\text { Pleistocene } \\
\text { to mid- } \\
\text { Holocene }\end{array}$ & $\begin{array}{l}\text { Paleo-South } \\
\text { American } \\
\text { hunter- } \\
\text { gatherers }\end{array}$ & $\begin{array}{l}\text { Various sites } \\
\text { in the Middle } \\
\text { Negro River } \\
\text { Basin } \\
\text { (Uruguay) } \\
\text { with special } \\
\text { reference to } \\
\text { Rincón del } \\
\text { Bonete }\end{array}$ & $\begin{array}{l}\text { Miniature } \\
\text { projectile } \\
\text { points } \\
\text { (“Fishtail } \\
\text { Points”) } \\
\text { interpreted } \\
\text { can be } \\
\text { interpreted } \\
\text { as toys. }\end{array}$ & $\begin{array}{l}\text { Dimensional } \\
\text { and } \\
\text { morphological } \\
\text { variations of } \\
\text { projectile points } \\
\text { likely include } \\
\text { toys; in addition, } \\
\text { abraded edges, } \\
\text { perhaps to } \\
\text { make them } \\
\text { safer for } \\
\text { children, further } \\
\text { point to their } \\
\text { being children's } \\
\text { tools/toys. }\end{array}$ & $\begin{array}{l}\text { Nami 2007; } \\
\text { Nami } 2013\end{array}$ \\
\hline $\begin{array}{l}\text { From ca. } \\
1000 \text { AD } \\
\text { onwards }\end{array}$ & Thule & $\begin{array}{l}\text { Various } \\
\text { sites, } \\
\text { Northern } \\
\text { Canada and } \\
\text { Greenland }\end{array}$ & $\begin{array}{l}\text { Various } \\
\text { children's } \\
\text { toys and } \\
\text { tools } \\
\text { including } \\
\text { hunting and } \\
\text { fishing } \\
\text { equipment, } \\
\text { miniaturise } \\
\text { d } \\
\text { transportati } \\
\text { on toys } \\
\text { (e.g. sleds, } \\
\text { boats), } \\
\text { knives, } \\
\text { miniaturise } \\
\text { d } \\
\text { household } \\
\text { toys, dolls. }\end{array}$ & $\begin{array}{l}\text { Small size and } \\
\text { ethnographic } \\
\text { comparison. }\end{array}$ & Park 1998 \\
\hline
\end{tabular}




\begin{tabular}{|c|c|c|c|c|c|}
\hline N.D. & Dorset & $\begin{array}{l}\text { Various } \\
\text { sites, Arctic } \\
\text { Canada and } \\
\text { Greenland }\end{array}$ & $\begin{array}{l}\text { Toy and } \\
\text { functional } \\
\text { hunting } \\
\text { tools } \\
\text { (harpoon } \\
\text { heads). }\end{array}$ & $\begin{array}{l}\text { Morphometrics, } \\
\text { comparative } \\
\text { analysis with } \\
\text { Thule material } \\
\text { culture and } \\
\text { ethnographic } \\
\text { data. }\end{array}$ & Park 2006 \\
\hline $\begin{array}{l}\text { Ca. } 500 \mathrm{BC} \\
\text { to } A D 1000 \\
\text { (ca. } 1500 \mathrm{BP} \\
\text { to ca. } 1000 \\
\text { BP) }\end{array}$ & Dorset & $\begin{array}{l}\text { Various } \\
\text { sites, Devon } \\
\text { Island and } \\
\text { Bathurst } \\
\text { Island } \\
\text { (Canada) }\end{array}$ & $\begin{array}{l}\text { Small } \\
\text { harpoon } \\
\text { heads as } \\
\text { functional } \\
\text { children's } \\
\text { tools. }\end{array}$ & Small size. & $\begin{array}{l}\text { Park and } \\
\text { Mousseau } \\
2003\end{array}$ \\
\hline Сa. 6400 BP & Paleoindian & $\begin{array}{l}\text { Ball: Arroyo } \\
\text { Seco 2, } \\
\text { Pampean } \\
\text { Region, } \\
\text { (Argentina); }\end{array}$ & $\begin{array}{l}\text { Black } \\
\text { basalt ball; } \\
\text { "Fishtail" } \\
\text { projectile } \\
\text { points. }\end{array}$ & $\begin{array}{l}\text { Ball associated } \\
\text { with child burial, } \\
\text { and } \\
\text { ethnographic } \\
\text { analogy. } \\
\text { Small and } \\
\text { poorly made } \\
\text { projectile points. }\end{array}$ & $\begin{array}{l}\text { Politis } \\
1998\end{array}$ \\
\hline Various & $\begin{array}{l}\text { Thule and } \\
\text { Magdalenian }\end{array}$ & $\begin{array}{l}\text { Various } \\
\text { sites, } \\
\text { Eurasia, } \\
\text { North } \\
\text { America }\end{array}$ & $\begin{array}{l}\text { Figurines, } \\
\text { bone discs } \\
\text { (rondelles), } \\
\text { miniature } \\
\text { tools. }\end{array}$ & $\begin{array}{l}\text { Reinterpreted } \\
\text { many objects as } \\
\text { toys through } \\
\text { cross-cultural } \\
\text { archaeological } \\
\text { and } \\
\text { ethnographic } \\
\text { comparison. }\end{array}$ & $\begin{array}{l}\text { Riede et al } \\
2018\end{array}$ \\
\hline $\begin{array}{l}\text { Ca. } \\
\text { BP }\end{array}$ & $\begin{array}{l}\text { Upper } \\
\text { Palaeolithic }\end{array}$ & $\begin{array}{l}\text { Bàsura Cave } \\
\text { (Italy) }\end{array}$ & $\begin{array}{l}\text { Documenta } \\
\text { tion of } \\
\text { many } \\
\text { different } \\
\text { types of } \\
\text { movement } \\
\text { and } \\
\text { activities, } \\
\text { including } \\
\text { playing with } \\
\text { clay. }\end{array}$ & $\begin{array}{l}\text { Studied } 180 \\
\text { human } \\
\text { footprints and } \\
\text { traces in a } \\
\text { particular part of } \\
\text { the cave using } \\
\text { multiple } \\
\text { methods, } \\
\text { including laser } \\
\text { scans, } \\
\text { sedimentology, } \\
\text { archaeobotany, } \\
\text { geometric } \\
\text { morphometrics } \\
\text { and } \\
\text { photogrammetr } \\
\text { y. }\end{array}$ & $\begin{array}{l}\text { Romano et } \\
\text { al. } 2019\end{array}$ \\
\hline $\begin{array}{l}17737 \pm 165 \\
\text { calBP or } 15\end{array}$ & Magdalenian & $\begin{array}{l}\text { Mannheim } \\
\text { (Germany) }\end{array}$ & $\begin{array}{l}\text { Fragment } \\
\text { of } a\end{array}$ & $\begin{array}{l}\text { Small size, } \\
\text { morphometrics }\end{array}$ & $\begin{array}{l}\text { Rosendahl } \\
\text { et al. } 2006\end{array}$ \\
\hline
\end{tabular}




\begin{tabular}{|l|l|l|l|l|l|}
\hline $\begin{array}{l}737 \pm 165 \\
\text { calBC } \\
\text { depending } \\
\text { on calibration }\end{array}$ & & & $\begin{array}{l}\text { wooden } \\
\text { artefact, } \\
\text { tentatively } \\
\text { interpreted } \\
\text { as possible } \\
\text { fragment of } \\
\text { child's bow. }\end{array}$ & $\begin{array}{l}\text { and } \\
\text { ethnographic } \\
\text { analogy. }\end{array}$ & \\
\hline $\begin{array}{l}\text { Upper } \\
\text { Palaeolithic }\end{array}$ & Mal'ta culture & $\begin{array}{l}\text { Mal'ta, } \\
\text { Siberia } \\
\text { (Russia) }\end{array}$ & $\begin{array}{l}\text { Bone discs, } \\
\text { necklace. }\end{array}$ & $\begin{array}{l}\text { Association with } \\
\text { child burial. } \\
\text { Note that } \\
\text { Sieveking does } \\
\text { not directly } \\
\text { interpret these } \\
\text { as children's } \\
\text { material culture. }\end{array}$ & $\begin{array}{l}\text { Sieveking } \\
1971\end{array}$ \\
\hline
\end{tabular}

${ }^{*}$ Dates are provided as reported in the publication. N.D. means no date/date range given in the publication cited.

TABLE 2. Evidence for Children Learning to Knap

\begin{tabular}{|c|c|c|c|c|c|}
\hline $\begin{array}{l}\text { Period } \\
\text { and/or } \\
\text { date(s)* }\end{array}$ & Culture & $\begin{array}{l}\text { Site(s) } \\
\text { and/or } \\
\text { Region }\end{array}$ & $\begin{array}{l}\text { Potential } \\
\text { Children's } \\
\text { Material } \\
\text { Culture or } \\
\text { Evidence }\end{array}$ & $\begin{array}{l}\text { How } \\
\text { Identified as } \\
\text { Evidence of } \\
\text { Child/Childr } \\
\text { en }\end{array}$ & Reference \\
\hline $\begin{array}{l}35,000 \text { to } \\
41,000 \mathrm{cal} \\
\text { BP }\end{array}$ & $\begin{array}{l}\text { Early } \\
\text { Aurignacian }\end{array}$ & $\begin{array}{l}\text { La Tuto de } \\
\text { Camalhot } \\
\text { (France) }\end{array}$ & $\begin{array}{l}\text { Errors in } \\
\text { production of } \\
\text { carinated } \\
\text { cores. }\end{array}$ & $\begin{array}{l}\text { Analysis and } \\
\text { scoring of } \\
\text { lithic } \\
\text { reduction } \\
\text { sequences. }\end{array}$ & $\begin{array}{l}\text { Anderson } \\
2018\end{array}$ \\
\hline N.D. & $\begin{array}{l}\text { Magdalenia } \\
\mathrm{n}\end{array}$ & $\begin{array}{l}\text { Various sites } \\
\text { in Paris } \\
\text { Basin and } \\
\text { Switzerland }\end{array}$ & $\begin{array}{l}\text { Knapping } \\
\text { errors, poor } \\
\text { core } \\
\text { maintenance. }\end{array}$ & $\begin{array}{l}\text { Chaîne } \\
\text { opératoire, } \\
\text { refitting, raw } \\
\text { material } \\
\text { sourcing. }\end{array}$ & $\begin{array}{l}\text { Audouze and } \\
\text { Cattin } 2011\end{array}$ \\
\hline $\begin{array}{l}\text { Ca. } 14,000 \\
\text { BP }\end{array}$ & $\begin{array}{l}\text { Late } \\
\text { Magdalenia } \\
\mathrm{n}\end{array}$ & $\begin{array}{l}\text { Verberie } \\
\text { (France) }\end{array}$ & $\begin{array}{l}\text { Knapping } \\
\text { errors, failure to } \\
\text { produce } \\
\text { blades. }\end{array}$ & $\begin{array}{l}\text { Technologica } \\
\text { I analysis, } \\
\text { refitting and } \\
\text { spatial } \\
\text { analysis. }\end{array}$ & $\begin{array}{l}\text { Audouze and } \\
\text { Janny } 2009\end{array}$ \\
\hline $\begin{array}{l}\text { Ca. } 10,800 \\
\text { to } 7200 \mathrm{BC}\end{array}$ & Paleoindian & $\begin{array}{l}\text { Medicine } \\
\text { Creek } \\
\text { Drainage } \\
\text { (Nebraska, } \\
\text { USA) }\end{array}$ & $\begin{array}{l}\text { Poor } \\
\text { manufacture of } \\
\text { projectile } \\
\text { points. }\end{array}$ & $\begin{array}{l}\text { Comparisons } \\
\text { of size and } \\
\text { symmetry of } \\
\text { lithic points. }\end{array}$ & $\begin{array}{l}\text { Bamforth } \\
\text { and Hicks } \\
2008\end{array}$ \\
\hline $\begin{array}{l}\text { Terminal } \\
\text { Pleistocene } \\
\text { into } \\
\text { Holocene, }\end{array}$ & & $\begin{array}{l}\text { Punta de la } \\
\text { Peña, } \\
\text { Quebrada } \\
\text { Seca and }\end{array}$ & $\begin{array}{l}\text { Lithic } \\
\text { procurement } \\
\text { and workshop } \\
\text { sites (quarries), }\end{array}$ & $\begin{array}{l}\text { Ethnographic } \\
\text { comparison, } \\
\text { proximity of } \\
\text { hunter- }\end{array}$ & $\begin{array}{l}\text { Bobillo and } \\
\text { Hocsman } \\
2015\end{array}$ \\
\hline
\end{tabular}




\begin{tabular}{|c|c|c|c|c|c|}
\hline $\begin{array}{l}\text { likely from } \\
4500 \mathrm{BP}\end{array}$ & & $\begin{array}{l}\text { Pampa } \\
\text { Oeste } \\
\text { Supply and } \\
\text { Quarry } \\
\text { Zones } \\
\text { (Argentina) }\end{array}$ & $\begin{array}{l}\text { with associated } \\
\text { evidence of } \\
\text { exploitation of } \\
\text { raw materials, } \\
\text { and lithic } \\
\text { reduction } \\
\text { sequences, } \\
\text { including more } \\
\text { rarely some } \\
\text { tools. }\end{array}$ & $\begin{array}{l}\text { gatherer } \\
\text { occupation } \\
\text { sites to the } \\
\text { quarries; } \\
\text { ease of } \\
\text { extracting } \\
\text { surface raw } \\
\text { materials, } \\
\text { knapping } \\
\text { errors and } \\
\text { poorly } \\
\text { executed } \\
\text { tools. }\end{array}$ & \\
\hline N.D. & $\begin{array}{l}\text { Magdalenia } \\
n\end{array}$ & $\begin{array}{l}\text { Pincevent } \\
\text { (France) }\end{array}$ & $\begin{array}{l}\text { Failures to } \\
\text { produce } \\
\text { blades, use of } \\
\text { poor quality } \\
\text { and irregularly } \\
\text { shaped raw } \\
\text { material, } \\
\text { presence of a } \\
\text { possible } \\
\text { 'academic core' } \\
\text { with most } \\
\text { products left in } \\
\text { place. }\end{array}$ & $\begin{array}{l}\text { Technologica } \\
\text { I analysis, } \\
\text { refitting and } \\
\text { spatial } \\
\text { analysis. }\end{array}$ & $\begin{array}{l}\text { Bodu et al. } \\
1990\end{array}$ \\
\hline N.D. & $\begin{array}{l}\text { Châtelperro } \\
\text { nian†, early } \\
\text { Aurignacian }\end{array}$ & $\begin{array}{l}\text { Canaule II } \\
\text { (France), } \\
\text { Corbiac- } \\
\text { Vignoble II } \\
\text { (France) }\end{array}$ & $\begin{array}{l}\text { Canaule II: } \\
\text { abundant } \\
\text { evidence of low } \\
\text { skill levels, core } \\
\text { preparation } \\
\text { flakes created } \\
\text { by skilled } \\
\text { knappers serve } \\
\text { as core blanks } \\
\text { for lower skilled } \\
\text { knappers. Lack } \\
\text { of skills to } \\
\text { efficiently } \\
\text { produce } \\
\text { blades. } \\
\text { Corbiac- } \\
\text { Vignoble II: } \\
\text { Low levels of } \\
\text { evidence of } \\
\text { unskilled } \\
\text { knapping, } \\
\text { represented by } \\
\text { a failure to } \\
\text { produce } \\
\text { bladelet cores. }\end{array}$ & $\begin{array}{l}\text { Qualitative } \\
\text { classification } \\
\text { of reduction } \\
\text { sequences to } \\
\text { analyse skill, } \\
\text { spatial } \\
\text { analysis. }\end{array}$ & $\begin{array}{l}\text { Bordes and } \\
\text { Bachellerie } \\
2018\end{array}$ \\
\hline
\end{tabular}




\begin{tabular}{|c|c|c|c|c|c|}
\hline N.D. & $\begin{array}{l}\text { Magdalenia } \\
\mathrm{n}\end{array}$ & $\begin{array}{l}\text { Champrévey } \\
\text { res and } \\
\text { Monruz, } \\
\text { (Switzerland) }\end{array}$ & $\begin{array}{l}\text { Knapping } \\
\text { errors including } \\
\text { poor core } \\
\text { preparation, } \\
\text { and reduction, } \\
\text { incorrect } \\
\text { placement of } \\
\text { strikes, hinge } \\
\text { terminations on } \\
\text { flakes. }\end{array}$ & $\begin{array}{l}\text { Intersite and } \\
\text { intrasite } \\
\text { refitting, } \\
\text { spatial } \\
\text { analysis. }\end{array}$ & Cattin 2010 \\
\hline $\begin{array}{l}\text { Ca. } 5,050 \\
B C \text { to } 650 \\
A D\end{array}$ & $\begin{array}{l}\text { American } \\
\text { Great Basin } \\
\text { Early to } \\
\text { Middle } \\
\text { Archaic }\end{array}$ & $\begin{array}{l}\text { Great Basin } \\
\text { Lithic Scatter } \\
\text { (Nevada, } \\
\text { USA) }\end{array}$ & $\begin{array}{l}\text { Novice } \\
\text { production of } \\
\text { projectile } \\
\text { points, as } \\
\text { evidenced by } \\
\text { step and hinge } \\
\text { scars and. } \\
\text { width/thickness } \\
\text { ratios. }\end{array}$ & $\begin{array}{l}\text { Chaîne } \\
\text { opératoire, } \\
\text { focusing on } \\
\text { dart } \\
\text { preforms; } \\
\text { refitting, } \\
\text { spatial } \\
\text { analysis, } \\
\text { comparative } \\
\text { analysis with } \\
\text { experimental } \\
\text { sample of } \\
\text { dart } \\
\text { preforms. }\end{array}$ & Cunnar 2015 \\
\hline $\begin{array}{l}\text { Ca. } 13,000 \\
\text { to } 12,000 \\
\text { cal BC }\end{array}$ & $\begin{array}{l}\text { Magdalenia } \\
\mathrm{n}\end{array}$ & $\begin{array}{l}\text { Pincevent } \\
\text { (France) and } \\
\text { Verberie } \\
\text { (France) }\end{array}$ & $\begin{array}{l}\text { Differences in } \\
\text { how microliths } \\
\text { were designed } \\
\text { is interpreted } \\
\text { as differences } \\
\text { in knapping } \\
\text { competence. }\end{array}$ & $\begin{array}{l}\text { Inter-site } \\
\text { comparison } \\
\text { of microlith } \\
\text { production. }\end{array}$ & Debout 2018 \\
\hline $\begin{array}{l}\text { Ca. } 12,700 \\
\text { cal BP }\end{array}$ & Bromme & $\begin{array}{l}\text { Trollesgave } \\
\text { (Denmark) }\end{array}$ & $\begin{array}{l}\text { Divergence } \\
\text { from patterns of } \\
\text { use-wear relate } \\
\text { to children who } \\
\text { produced, used } \\
\text { and discarded } \\
\text { lithic tools in } \\
\text { anomalous } \\
\text { ways. }\end{array}$ & $\begin{array}{l}\text { Use-wear } \\
\text { analysis. }\end{array}$ & $\begin{array}{l}\text { Donahue } \\
\text { and Fischer } \\
2015\end{array}$ \\
\hline $\begin{array}{l}\text { Ca. } 10,000 \\
\text { to } 9,000 \mathrm{BP}\end{array}$ & $\begin{array}{l}\text { Early } \\
\text { Mesolithic }\end{array}$ & $\begin{array}{l}\text { Site } 3 \text { on the } \\
\text { island of } \\
\text { Hundvåg } \\
\text { (Norway) }\end{array}$ & $\begin{array}{l}\text { Mistakes in axe } \\
\text { manufacture, } \\
\text { implying a poor } \\
\text { grasp of } \\
\text { technological } \\
\text { principles. }\end{array}$ & $\begin{array}{l}\text { Technologica } \\
\text { I analysis, } \\
\text { refitting, and } \\
\text { spatial } \\
\text { analysis. }\end{array}$ & $\begin{array}{l}\text { Dugstad } \\
2010\end{array}$ \\
\hline $\begin{array}{l}6300 \text { to } \\
4000 \text { cal } \\
B C\end{array}$ & $\begin{array}{l}\text { Late } \\
\text { Mesolithic }\end{array}$ & $\begin{array}{l}\text { Six sites in } \\
\text { eastern } \\
\text { Norway }\end{array}$ & $\begin{array}{l}\text { Mistakes in } \\
\text { reduction of } \\
\text { cores that }\end{array}$ & $\begin{array}{l}\text { Technologica } \\
\text { I analysis, } \\
\text { comparison }\end{array}$ & $\begin{array}{l}\text { Eigeland } \\
2011\end{array}$ \\
\hline
\end{tabular}




\begin{tabular}{|c|c|c|c|c|c|}
\hline & & & $\begin{array}{l}\text { cannot be } \\
\text { attributed to } \\
\text { quality of raw } \\
\text { material. }\end{array}$ & $\begin{array}{l}\text { with } \\
\text { experimental } \\
\text { sample. }\end{array}$ & \\
\hline $\begin{array}{l}\text { Coulerlerac } \\
\text { h: } \\
7,530 \pm 80 \\
\text { uncal BP } \\
\text { Lough } \\
\text { Boora: } \\
8,520 \pm 50 \\
\text { uncal BP } \\
\text { and } \\
8,345 \pm 50 \\
\text { uncal BP }\end{array}$ & Mesolithic & $\begin{array}{l}\text { Coulerlerach } \\
\text { (Scotland) } \\
\text { and Lough } \\
\text { Boora } \\
\text { (Ireland) }\end{array}$ & $\begin{array}{l}\text { Coulerlerach: } \\
\text { cores covered } \\
\text { in } \\
\text { hammermarks, } \\
\text { attributed to } \\
\text { novices. } \\
\text { Lough Boora: } \\
\text { assemblage } \\
\text { displaying } \\
\text { variable skill } \\
\text { levels, including } \\
\text { a mixed-ability } \\
\text { core, and } \\
\text { idiosyncratic } \\
\text { platform } \\
\text { preparation. }\end{array}$ & $\begin{array}{l}\text { Lithic } \\
\text { assemblage } \\
\text { analyses. }\end{array}$ & Finlay 2015 \\
\hline $\begin{array}{l}\text { Ca. } 12,000 \\
\text { to } 11,100 \\
\text { BP }\end{array}$ & Bromme & $\begin{array}{l}\text { Trollesgave } \\
\text { (Denmark) }\end{array}$ & $\begin{array}{l}\text { Differences in } \\
\text { skill levels } \\
\text { present in } \\
\text { lithics at the } \\
\text { site, including } \\
\text { poor platform } \\
\text { preparation, } \\
\text { and less } \\
\text { precision and } \\
\text { force in striking } \\
\text { cores. } \\
\text { Distribution of } \\
\text { refitting } \\
\text { debitage } \\
\text { related to poor } \\
\text { production is } \\
\text { anomalous to } \\
\text { the wider site } \\
\text { pattern. }\end{array}$ & $\begin{array}{l}\text { Technologica } \\
\text { I analysis, } \\
\text { refitting, } \\
\text { spatial } \\
\text { analysis, and } \\
\text { comparative } \\
\text { analysis with } \\
\text { experimental } \\
\text { sample. }\end{array}$ & $\begin{array}{l}\text { Fischer } \\
\text { 1990a }\end{array}$ \\
\hline $11,000 \mathrm{BP}$ & Bromme & $\begin{array}{l}\text { Trollesgave } \\
\text { (Denmark) }\end{array}$ & $\begin{array}{l}\text { Poor platform } \\
\text { preparation, } \\
\text { poorly } \\
\text { controlled } \\
\text { strikes, and } \\
\text { irregular flake } \\
\text { production. } \\
\text { Distribution of } \\
\text { refitting } \\
\text { debitage } \\
\text { related to this }\end{array}$ & $\begin{array}{l}\text { Technologica } \\
\text { I analysis, } \\
\text { refitting, } \\
\text { spatial } \\
\text { analysis, and } \\
\text { comparative } \\
\text { analysis with } \\
\text { experimental } \\
\text { sample. }\end{array}$ & $\begin{array}{l}\text { Fischer } \\
\qquad \begin{array}{c}1990 \\
\text { b }\end{array}\end{array}$ \\
\hline
\end{tabular}




\begin{tabular}{|c|c|c|c|c|c|}
\hline & & & $\begin{array}{l}\text { poor production } \\
\text { is anomalous to } \\
\text { the wider site } \\
\text { pattern. }\end{array}$ & & \\
\hline N.D. & Perigordian & $\begin{array}{l}\text { Solvieux } \\
\text { (France) }\end{array}$ & $\begin{array}{l}\text { A single } \\
\text { flintknapping } \\
\text { episode } \\
\text { comprising core } \\
\text { reduction, } \\
\text { undertaken by } \\
\text { someone } \\
\text { determined to } \\
\text { be at } \\
\text { apprentice } \\
\text { level. }\end{array}$ & $\begin{array}{l}\text { Chaîne } \\
\text { opératoire, } \\
\text { refitting and } \\
\text { spatial } \\
\text { analysis. }\end{array}$ & Grimm 2000 \\
\hline $\begin{array}{l}\text { Ca. } 72,000 \\
\text { to } 80,000 \\
\text { BP }\end{array}$ & Still Bay & $\begin{array}{l}\text { Hollow Rock } \\
\text { Shelter } \\
\text { (South } \\
\text { Africa) }\end{array}$ & $\begin{array}{l}\text { A small sample } \\
\text { of the } \\
\text { assemblage } \\
\text { displays } \\
\text { mistakes } \\
\text { consistent with } \\
\text { novice } \\
\text { knapping. } \\
\text { Evidence of } \\
\text { experimentatio } \\
\text { n, revealing a } \\
\text { creative } \\
\text { learning } \\
\text { process. }\end{array}$ & $\begin{array}{l}\text { Chaîne } \\
\text { opératoire } \\
\text { and attribute } \\
\text { analysis. }\end{array}$ & $\begin{array}{l}\text { Högberg and } \\
\text { Larsson } \\
2011\end{array}$ \\
\hline $\begin{array}{l}\text { Late Upper } \\
\text { Palaeolithic } \\
\text { (Late } \\
\text { Glacial) }\end{array}$ & Creswillian & $\begin{array}{l}\text { Gough's } \\
\text { Cave (U.K.) }\end{array}$ & $\begin{array}{l}\text { Presence of } \\
\text { cores with } \\
\text { irregular final } \\
\text { removals } \\
\text { suggesting } \\
\text { activities of an } \\
\text { apprentice. }\end{array}$ & $\begin{array}{l}\text { Assemblage } \\
\text { analysis. }\end{array}$ & Jacobi 2004 \\
\hline $\begin{array}{l}14,000 \text { to } \\
12,000 \mathrm{cal} \\
\mathrm{BP}\end{array}$ & $\begin{array}{l}\text { Magdalenia } \\
\mathrm{n}\end{array}$ & $\begin{array}{l}\text { Verberie } \\
\text { (France) }\end{array}$ & $\begin{array}{l}\text { Lithic } \\
\text { assemblage } \\
\text { demonstrates a } \\
\text { range of skill } \\
\text { levels from very } \\
\text { young children } \\
\text { lacking motor } \\
\text { control resulting } \\
\text { in failure to } \\
\text { remove flakes } \\
\text { through to } \\
\text { highly skilled } \\
\text { flintknappers. }\end{array}$ & $\begin{array}{l}\text { Chaîne } \\
\text { opératoire. }\end{array}$ & Janny 2010 \\
\hline
\end{tabular}




\begin{tabular}{|c|c|c|c|c|c|}
\hline N.D. & $\begin{array}{l}\text { Magdalenia } \\
\mathrm{n}\end{array}$ & $\begin{array}{l}\text { Etiolles } \\
\text { (France) } \\
\text { Pincevent } \\
\text { (France) }\end{array}$ & $\begin{array}{l}\text { Lithic } \\
\text { assemblages } \\
\text { demonstrate a } \\
\text { range of skill } \\
\text { levels. At } \\
\text { Etiolles } \\
\text { knapping } \\
\text { abilities appear } \\
\text { to have been } \\
\text { organised in } \\
\text { zones, whereas } \\
\text { this was not } \\
\text { evidenced at } \\
\text { Pincevent. }\end{array}$ & $\begin{array}{l}\text { Chaîne } \\
\text { opératoire, } \\
\text { inter-site } \\
\text { comparison, } \\
\text { use of areas } \\
\text { for different } \\
\text { activities. }\end{array}$ & $\begin{array}{l}\text { Karlin et al. } \\
1993\end{array}$ \\
\hline N.D. & $\begin{array}{l}\text { Aurignacian } \\
\text {, Gravettian }\end{array}$ & $\begin{array}{l}\text { Corbiac- } \\
\text { Vignoble 2, } \\
\text { Tercis, } \\
\text { Solvieux, } \\
\text { Grand- } \\
\text { Pressigny at } \\
\text { La Picardie } \\
\text { (all France) }\end{array}$ & $\begin{array}{l}\text { Novice } \\
\text { flintknappers } \\
\text { were evidenced } \\
\text { at all sites, but } \\
\text { some site } \\
\text { assemblages } \\
\text { suggested a } \\
\text { greater } \\
\text { presence of } \\
\text { lower skilled } \\
\text { knapping than } \\
\text { others. }\end{array}$ & $\begin{array}{l}\text { Technologica } \\
\text { I study } \\
\text { involving an } \\
\text { assessment } \\
\text { grid for } \\
\text { scoring } \\
\text { knapping } \\
\text { errors, } \\
\text { focused on } \\
\text { bladelet } \\
\text { production. }\end{array}$ & Klaric 2018 \\
\hline $\begin{array}{l}15,500 \\
\text { calBP }\end{array}$ & $\begin{array}{l}\text { Magdalenia } \\
\mathrm{n}\end{array}$ & $\begin{array}{l}\text { Verberie II.1 } \\
\text { (France) }\end{array}$ & $\begin{array}{l}\text { Evidence of } \\
\text { unskilled } \\
\text { knapping, e.g. } \\
\text { poor strikes } \\
\text { and ineffective } \\
\text { reduction of } \\
\text { cores. }\end{array}$ & $\begin{array}{l}\text { Chaîne } \\
\text { opératoire. }\end{array}$ & $\begin{array}{l}\text { Langlais } \\
2018\end{array}$ \\
\hline $\begin{array}{l}2,250 \text { to } \\
800 \mathrm{BC}\end{array}$ & Pre-Dorset & $\begin{array}{l}\text { Multiple } \\
\text { (Canada) }\end{array}$ & $\begin{array}{l}\text { Lithics } \\
\text { displaying } \\
\text { evidence of } \\
\text { novice } \\
\text { knapping } \\
\text { including e.g. } \\
\text { battered cores, } \\
\text { hinge and step } \\
\text { terminations, } \\
\text { and sinuous } \\
\text { edges on } \\
\text { bifaces. }\end{array}$ & $\begin{array}{l}\text { Inter-site } \\
\text { comparison } \\
\text { of lithic } \\
\text { assemblages }\end{array}$ & Milne 2005 \\
\hline N.D. & $\begin{array}{l}\text { Aurignacian } \\
\text {, Gravettian, } \\
\text { Solutrean }\end{array}$ & $\begin{array}{l}\text { Barbas III, } \\
\text { Vieux } \\
\text { Coutets, La } \\
\text { Doline, } \\
\text { Cantalouette }\end{array}$ & $\begin{array}{l}\text { Different } \\
\text { chrono-cultural } \\
\text { contexts and } \\
\text { occupation } \\
\text { types display }\end{array}$ & $\begin{array}{l}\text { Inter-site } \\
\text { comparison } \\
\text { of lithic } \\
\text { assemblages } \\
\text {, focusing on }\end{array}$ & $\begin{array}{l}\text { Ortega- } \\
\text { Cordellat } \\
2018\end{array}$ \\
\hline
\end{tabular}




\begin{tabular}{|c|c|c|c|c|c|}
\hline & & \begin{tabular}{l|}
, Garris 2, \\
Canolle "La \\
Ferme", Petit \\
Rooy, La \\
Graulet 6 (all \\
Bergerac \\
region, \\
France)
\end{tabular} & $\begin{array}{l}\text { evidence of } \\
\text { different skill } \\
\text { levels. Lack of } \\
\text { skill } \\
\text { represented in } \\
\text { poor blank } \\
\text { selection, } \\
\text { knapping } \\
\text { errors, etc. }\end{array}$ & $\begin{array}{l}\text { uniformity or } \\
\text { otherwise } \\
\text { technical } \\
\text { systems, and } \\
\text { deviations } \\
\text { from them. }\end{array}$ & \\
\hline $\begin{array}{l}\text { Late } \\
\text { Pleistocene } \\
\text { through } \\
\text { early } \\
\text { Holocene }\end{array}$ & $\begin{array}{l}\text { Kongemose } \\
\text { and } \\
\text { Ertebølle, } \\
\text { Mesolithic }\end{array}$ & $\begin{array}{l}\text { Vedbæk } \\
\text { (Denmark) }\end{array}$ & $\begin{array}{l}\text { Presence of } \\
\text { cores from } \\
\text { Gøngehusvej } 7 \\
\text { displaying } \\
\text { evidence of } \\
\text { working by } \\
\text { children, } \\
\text { including small } \\
\text { nodules with a } \\
\text { single flake } \\
\text { removal. }\end{array}$ & $\begin{array}{l}\text { Artefact } \\
\text { assemblage } \\
\text { analyses. }\end{array}$ & $\begin{array}{l}\text { Petersen et } \\
\text { al. } 2015\end{array}$ \\
\hline N.D. & $\begin{array}{l}\text { Magdalenia } \\
\mathrm{n}\end{array}$ & $\begin{array}{l}\text { Étiolles } \\
\text { (France) }\end{array}$ & $\begin{array}{l}\text { Clusters of } \\
\text { debitage } \\
\text { showing high } \\
\text { rates of errors, } \\
\text { non- } \\
\text { productivity, } \\
\text { and products } \\
\text { remaining at } \\
\text { knapping } \\
\text { locations. }\end{array}$ & $\begin{array}{l}\text { Chaîne } \\
\text { opératoire. }\end{array}$ & Pigeot 1990 \\
\hline N.D. & $\begin{array}{l}\text { Magdalenia } \\
\mathrm{n}\end{array}$ & $\begin{array}{l}\text { Verberie } \\
\text { (France) }\end{array}$ & $\begin{array}{l}\text { Errors in } \\
\text { resharpening a } \\
\text { lithic tool; } \\
\text { irregular choice } \\
\text { of blank for tool } \\
\text { production. }\end{array}$ & $\begin{array}{l}\text { Use-wear } \\
\text { analysis. }\end{array}$ & Rots 2005 \\
\hline N.D. & Gravettian & $\begin{array}{l}\text { Tercis } \\
\text { (France) }\end{array}$ & $\begin{array}{l}\text { Irregularities } \\
\text { and deviations } \\
\text { from } \\
\text { standardised } \\
\text { ways of } \\
\text { working flint, } \\
\text { e.g. choosing } \\
\text { blanks for } \\
\text { projectile point } \\
\text { manufacture } \\
\text { that could } \\
\text { never have } \\
\text { been functional, } \\
\text { choice of poor }\end{array}$ & $\begin{array}{l}\text { Chaîne } \\
\text { opératoire. }\end{array}$ & $\begin{array}{l}\text { Simonet } \\
2009\end{array}$ \\
\hline
\end{tabular}




\begin{tabular}{|c|c|c|c|c|c|}
\hline & & & $\begin{array}{l}\text { raw materials } \\
\text { when good } \\
\text { quality material } \\
\text { is readily } \\
\text { available. }\end{array}$ & & \\
\hline N.D. & Gravettian & $\begin{array}{l}\text { Tercis } \\
\text { (France) }\end{array}$ & $\begin{array}{l}\text { Incomplete } \\
\text { retouch of } \\
\text { backed pieces } \\
\text { and deviation } \\
\text { from norms } \\
\text { seen at other } \\
\text { contemporary } \\
\text { sites, high level } \\
\text { of variability in } \\
\text { selection of } \\
\text { blanks. }\end{array}$ & $\begin{array}{l}\text { Chaîne } \\
\text { opératoire }\end{array}$ & $\begin{array}{l}\text { Simonet } \\
2012\end{array}$ \\
\hline $\begin{array}{l}23,000 \text { to } \\
26,000 \\
\text { uncal BP }\end{array}$ & Gravettian & $\begin{array}{l}\text { Tercis } \\
\text { (France), } \\
\text { Brassempou } \\
\text { y (France) }\end{array}$ & $\begin{array}{l}\text { Different skill } \\
\text { levels } \\
\text { represented at } \\
\text { both sites, with } \\
\text { apprentice } \\
\text { knapping } \\
\text { evidenced by } \\
\text { e.g. errors, } \\
\text { failure to } \\
\text { remove blades, } \\
\text { use of hard- } \\
\text { hammer } \\
\text { percussion. }\end{array}$ & $\begin{array}{l}\text { Intersite } \\
\text { comparison } \\
\text { of lithic } \\
\text { assemblages } \\
\text {, involving } \\
\text { chaîne } \\
\text { opératoire, } \\
\text { refitting and } \\
\text { spatial } \\
\text { analyses. }\end{array}$ & $\begin{array}{l}\text { Simonet } \\
2018\end{array}$ \\
\hline $\begin{array}{l}4,800 \text { to } \\
4,000 \text { cal } \\
\text { BP }\end{array}$ & Mesolithic & $\begin{array}{l}\text { Ferriter's } \\
\text { Cove } \\
\text { (Ireland), } \\
\text { Derragh } \\
\text { (Ireland) }\end{array}$ & $\begin{array}{l}\text { Different skill } \\
\text { levels in } \\
\text { reduction, } \\
\text { related to raw } \\
\text { material. }\end{array}$ & $\begin{array}{l}\text { Exploration } \\
\text { of differential } \\
\text { use of raw } \\
\text { materials } \\
\text { during } \\
\text { knapping } \\
\text { skill } \\
\text { transmission } \\
\text { in flint-poor } \\
\text { regions. }\end{array}$ & Sternke 2011 \\
\hline N.D. & $\begin{array}{l}\text { Late } \\
\text { Ertebølle }\end{array}$ & $\begin{array}{l}\text { Sparregård } \\
\text { (Denmark) }\end{array}$ & $\begin{array}{l}\text { Indicators of } \\
\text { bipolar } \\
\text { knapping on an } \\
\text { anvil, knapping } \\
\text { and concept } \\
\text { errors, absence } \\
\text { of } \\
\text { standardisation, } \\
\text { and lack of core } \\
\text { maintenance. }\end{array}$ & $\begin{array}{l}\text { Technologica } \\
\text { I and } \\
\text { morphologic } \\
\text { al analysis of } \\
\text { lithic } \\
\text { assemblage, } \\
\text { including } \\
\text { comparative } \\
\text { experimental } \\
\text { sample. }\end{array}$ & $\begin{array}{l}\text { Sternke and } \\
\text { Sørensen } \\
2009\end{array}$ \\
\hline
\end{tabular}




\begin{tabular}{|c|c|c|c|c|c|}
\hline $\begin{array}{l}17,000 \text { to } \\
14,000 \text { cal } \\
\mathrm{BP}\end{array}$ & $\begin{array}{l}\text { Japanese } \\
\text { Upper } \\
\text { Paleolithic }\end{array}$ & $\begin{array}{l}\text { Shirataki } \\
\text { sites (Japan) }\end{array}$ & $\begin{array}{l}\text { Evidence of } \\
\text { novice } \\
\text { knapping, as } \\
\text { well as } \\
\text { presence of } \\
\text { refitted sets } \\
\text { implying } \\
\text { pedagogical } \\
\text { knapping } \\
\text { demonstrations }\end{array}$ & $\begin{array}{l}\text { Technologica } \\
\text { I analysis, } \\
\text { refitting and } \\
\text { spatial } \\
\text { analysis. }\end{array}$ & $\begin{array}{l}\text { Takakura } \\
2013\end{array}$ \\
\hline $\begin{array}{l}\text { Broadly } \\
\text { contempor } \\
\text { ary with } \\
\text { Star Carr, } \\
\text { which is } \\
\text { dated from } \\
9385-9260 \\
\text { cal BC to } \\
\text { ca. 8555- } \\
8380 \text { cal } \\
\text { BC }\end{array}$ & $\begin{array}{l}\text { Early } \\
\text { Mesolithic }\end{array}$ & $\begin{array}{l}\text { Vale of } \\
\text { Pickering: } \\
\text { Seamer Carr } \\
\text { Site C and } \\
\text { VPD, North } \\
\text { Yorkshire } \\
\text { (U.K) }\end{array}$ & $\begin{array}{l}\text { Poor quality } \\
\text { knapping; low } \\
\text { productivity. }\end{array}$ & $\begin{array}{l}\text { Technologica } \\
\text { I analyses, } \\
\text { refitting and } \\
\text { spatial } \\
\text { analyses. }\end{array}$ & $\begin{array}{l}\text { Taylor et al. } \\
2018, \text { p. } 260\end{array}$ \\
\hline N.D. & $\begin{array}{l}\text { Palaeoltihic } \\
\text { and } \\
\text { Paleoindian }\end{array}$ & NA & $\begin{array}{l}\text { Spurs on } \\
\text { scrapers may } \\
\text { occur as a } \\
\text { result of } \\
\text { inexperienced } \\
\text { use, as } \\
\text { ethnographicall } \\
\text { y they } \\
\text { represent } \\
\text { mistakes. }\end{array}$ & $\begin{array}{l}\text { Primarily } \\
\text { ethnographic } \\
\text {, relates to } \\
\text { archaeologic } \\
\text { al } \\
\text { phenomenon } \\
\text { of spurs on } \\
\text { scrapers. }\end{array}$ & $\begin{array}{l}\text { Weedman } \\
2002\end{array}$ \\
\hline
\end{tabular}

* As reported in the publication. N.D. means No Date(s) reported. NA means Not Applicable. †Note that this review acknowledges the debates around the authorship of the Chatelperronian, and includes it in this table as the publication designates both industries as 'Early Upper Palaeolithic'.

TABLE 3. Evidence of Children's Marks, Art and Tracks

\begin{tabular}{|l|l|l|l|l|l|}
\hline $\begin{array}{l}\text { Period } \\
\text { and/or } \\
\text { date(s) }\end{array}$ & Culture & $\begin{array}{l}\text { Site(s) } \\
\text { and/or } \\
\text { Region }\end{array}$ & $\begin{array}{l}\text { Potential } \\
\text { Children's } \\
\text { Material } \\
\text { Culture or } \\
\text { Evidence }\end{array}$ & $\begin{array}{l}\text { How Identified } \\
\text { as Evidence of } \\
\text { Child/Children }\end{array}$ & $\begin{array}{l}\text { Referenc } \\
\text { e }\end{array}$ \\
\hline N.D. & $\begin{array}{l}\text { Upper } \\
\text { Palaeolithi } \\
\text { c }\end{array}$ & Europe & $\begin{array}{l}\text { Palaeolithic } \\
\text { bone discs with } \\
\text { carving on two } \\
\text { sides as } \\
\text { possible } \\
\text { thaumatropes, }\end{array}$ & $\begin{array}{l}\text { Contextualises } \\
\text { Palaeolithic art } \\
\text { as educational } \\
\text { device. }\end{array}$ & $\begin{array}{l}\text { Azéma } \\
\text { and } \\
\text { Rivère } \\
2012\end{array}$ \\
\hline
\end{tabular}




\begin{tabular}{|c|c|c|c|c|c|}
\hline & & & $\begin{array}{l}\text { i.e. as 'optical } \\
\text { toys'; parietal art } \\
\text { is discussed as } \\
\text { potential } \\
\text { educational } \\
\text { device. }\end{array}$ & & \\
\hline $\begin{array}{l}7,920- \\
6,600 \text { years } \\
{ }^{14} \text { C BP }\end{array}$ & $\begin{array}{l}\text { Ancient } \\
\text { Pampean } \\
\text { Hunter- } \\
\text { Gatherers }\end{array}$ & $\begin{array}{l}\text { Monte } \\
\text { Hermoso I, } \\
\text { Atlantic } \\
\text { Coast, } \\
\text { Argentina }\end{array}$ & $\begin{array}{l}\text { Hundreds of } \\
\text { footprints of } \\
\text { women, youths } \\
\text { and children } \\
\text { along prehistoric } \\
\text { pond. }\end{array}$ & $\begin{array}{l}\text { Size of } \\
\text { footprints. }\end{array}$ & $\begin{array}{l}\text { Bayón } \\
\text { and Politis } \\
1996 ; \mathrm{Ba} \\
\text { yón et al. } \\
2011\end{array}$ \\
\hline N.D. & Various & $\begin{array}{l}\text { Europe and } \\
\text { Australia }\end{array}$ & $\begin{array}{l}\text { Proposes that } \\
\text { certain finger } \\
\text { flutings in caves } \\
\text { may have been } \\
\text { made by } \\
\text { juveniles on the } \\
\text { basis of their } \\
\text { smaller } \\
\text { dimensions } \\
\text { (finger size, } \\
\text { finger spacings). }\end{array}$ & $\begin{array}{l}\text { Descriptive } \\
\text { exploration of } \\
\text { finger flutings in } \\
\text { multiple cave } \\
\text { sites. }\end{array}$ & $\begin{array}{l}\text { Bednarik } \\
1986\end{array}$ \\
\hline N.D. & $\begin{array}{l}\text { Magdaleni } \\
\text { an }\end{array}$ & $\begin{array}{l}\text { Hohle Fels } \\
\text { (Germany) } \\
\text { Kleine } \\
\text { Scheuer, } \\
\text { (Germany) } \\
\text { Obere } \\
\text { Klause } \\
\text { (Germany) }\end{array}$ & $\begin{array}{l}\text { Note that } \\
\text { Bednarik does } \\
\text { not mention } \\
\text { children, or } \\
\text { experimental } \\
\text { comparison in } \\
\text { this publication, } \\
\text { but rather in a } \\
\text { subsequent } \\
\text { review paper } \\
\text { (Bednarik } \\
\text { 2008). }\end{array}$ & $\begin{array}{l}\text { Plaques, } \\
\text { imprinted with } \\
\text { paint that was } \\
\text { stamped on } \\
\text { using finger } \\
\text { tips. }\end{array}$ & $\begin{array}{l}\text { Bednarik } \\
2002\end{array}$ \\
\hline $\begin{array}{l}>10,000 \text { cal } \\
\text { BP }\end{array}$ & $\begin{array}{l}\text { Paleoindia } \\
\mathrm{n}\end{array}$ & $\begin{array}{l}\text { White Sands } \\
\text { National } \\
\text { Park, New } \\
\text { Mexico } \\
\text { (USA) }\end{array}$ & $\begin{array}{l}\text { Footprints of } \\
\text { adult carrying } \\
\text { child on } 1.5 \\
\text { kilometre } \\
\text { journey; } \\
\text { occasional } \\
\text { footprints of } \\
\text { child when set } \\
\text { down. }\end{array}$ & $\begin{array}{l}\text { Sizes of the } \\
\text { footprints. }\end{array}$ & $\begin{array}{l}\text { Bennett et } \\
\text { al. } 2020\end{array}$ \\
\hline $\begin{array}{l}\text { Various } \\
\text { dates for } \\
\text { different } \\
\text { caves, } \\
\text { spanning }\end{array}$ & $\begin{array}{l}\text { Gravettian } \\
\text { and } \\
\text { Magdaleni } \\
\text { an }\end{array}$ & $\begin{array}{l}\text { Rouffignac } \\
\text { (France), } \\
\text { Gargas } \\
\text { (France), El } \\
\text { Castillo }\end{array}$ & $\begin{array}{l}\text { Small sizes of } \\
\text { some flutings } \\
\text { show that } \\
\text { children made } \\
\text { parietal art }\end{array}$ & $\begin{array}{l}\text { Morphometric } \\
\text { analysis of } \\
\text { flutings to } \\
\text { establish both } \\
\text { age and sex. }\end{array}$ & $\begin{array}{l}\text { Cooney } \\
\text { Williams } \\
\text { and Janik } \\
2018\end{array}$ \\
\hline
\end{tabular}




\begin{tabular}{|c|c|c|c|c|c|}
\hline $\begin{array}{l}\text { between } \\
\text { ca. } 31,000 \\
\text { to ca. } \\
14,900 \text { cal } \\
\text { BP }\end{array}$ & & $\begin{array}{l}\text { (Spain), Las } \\
\text { Chimeneas } \\
\text { (Spain), El } \\
\text { Cudón } \\
\text { (Spain), } \\
\text { Hornos de la } \\
\text { Peña (Spain) }\end{array}$ & $\begin{array}{l}\text { along with } \\
\text { adults. }\end{array}$ & & \\
\hline $\begin{array}{l}\text { Bracketed } \\
\text { between } \\
\text { ca. } 17,000 \\
\text { and } 23,000 \\
\text { BP }\end{array}$ & $\begin{array}{l}\text { Aboriginal } \\
\text { peoples of } \\
\text { the Last } \\
\text { Glacial } \\
\text { Maximum }\end{array}$ & $\begin{array}{l}\text { Shoreline } \\
\text { between } \\
\text { Lakes } \\
\text { Garnpung } \\
\text { and Leaghur, } \\
\text { New South } \\
\text { Wales } \\
\text { (Australia) }\end{array}$ & $\begin{array}{l}\text { Crescent- } \\
\text { shaped grooves } \\
\text { in the hardpan, } \\
\text { associated with } \\
\text { footprints of } \\
\text { children, are } \\
\text { interpreted as } \\
\text { possible finger } \\
\text { flutings. }\end{array}$ & $\begin{array}{l}\text { Indigenous } \\
\text { Australian } \\
\text { (Pintubi) } \\
\text { investigation } \\
\text { and } \\
\text { interpretation. }\end{array}$ & $\begin{array}{l}\text { Franklin } \\
\text { and } \\
\text { Hagbood } \\
2009\end{array}$ \\
\hline N.D. & $\begin{array}{l}\text { Magdaleni } \\
\text { an }\end{array}$ & $\begin{array}{l}\text { Réseau } \\
\text { Clastres } \\
\text { (France) }\end{array}$ & $\begin{array}{l}\text { Footprints in the } \\
\text { cave belonged } \\
\text { to three } \\
\text { children, } \\
\text { possibly in the } \\
\text { company of a } \\
\text { woman and a } \\
\text { man, or possibly } \\
\text { woman was an } \\
\text { adolescent. }\end{array}$ & $\begin{array}{l}\text { Morphometric } \\
\text { analysis of } \\
\text { footprints in the } \\
\text { cave. }\end{array}$ & $\begin{array}{l}\text { Garcia et } \\
\text { al. } 1990\end{array}$ \\
\hline N.D. & $\begin{array}{l}\text { Upper } \\
\text { Palaeolithi } \\
\text { c }\end{array}$ & $\begin{array}{l}\text { Grotte de } \\
\text { Gargas } \\
\text { (France), } \\
\text { Grotte de } \\
\text { Tibiran } \\
\text { (France) }\end{array}$ & $\begin{array}{l}\text { Handprints } \\
\text { come from both } \\
\text { sexes and all } \\
\text { age classes, } \\
\text { from infant } \\
\text { through adult. }\end{array}$ & $\begin{array}{l}\text { Comparison of } \\
\text { handprints } \\
\text { (negatives) in } \\
\text { caves with } \\
\text { experimentally } \\
\text { produced } \\
\text { prints. }\end{array}$ & $\begin{array}{l}\text { Groënen } \\
1988\end{array}$ \\
\hline N.D. & $\begin{array}{l}\text { Aboriginal } \\
\text { Australian }\end{array}$ & $\begin{array}{l}\text { Orchestra } \\
\text { Shell Cave } \\
\text { (Western } \\
\text { Australia), } \\
\text { Ross's cave } \\
\text { (Western } \\
\text { Australia) }\end{array}$ & $\begin{array}{l}\text { Finger flutings in } \\
\text { Ross's cave } \\
\text { probably made } \\
\text { by children, on } \\
\text { basis of } \\
\text { comparison with } \\
\text { author's own } \\
\text { hands. } \\
\text { Suggests } \\
\text { markings in } \\
\text { Orchestra Shell } \\
\text { Cave not likely } \\
\text { to have been } \\
\text { made by hands } \\
\text { at all. }\end{array}$ & $\begin{array}{l}\text { Recorded } \\
\text { markings in } \\
\text { caves, including } \\
\text { finger spacings, } \\
\text { primarily } \\
\text { descriptive, } \\
\text { makes } \\
\text { comparisons } \\
\text { with further } \\
\text { caves. }\end{array}$ & $\begin{array}{l}\text { Hallam } \\
1971\end{array}$ \\
\hline
\end{tabular}




\begin{tabular}{|c|c|c|c|c|c|}
\hline N.D. & $\begin{array}{l}\text { Upper } \\
\text { Palaeolithi } \\
\text { c }\end{array}$ & Various & $\begin{array}{l}\text { Proposes that } \\
\text { imagery } \\
\text { functioned as } \\
\text { educational } \\
\text { tools. }\end{array}$ & $\begin{array}{l}\text { Describes } \\
\text { multiple } \\
\text { examples of } \\
\text { Upper } \\
\text { Palaeolithic } \\
\text { images and } \\
\text { relates them to } \\
\text { methods used } \\
\text { by } \\
\text { contemporary } \\
\text { hunter- } \\
\text { gatherers to } \\
\text { gather } \\
\text { information on } \\
\text { their } \\
\text { environment. }\end{array}$ & $\begin{array}{l}\text { Mithen } \\
1988\end{array}$ \\
\hline $\begin{array}{l}\text { From ca. } \\
40,000 \text { to } \\
10,000 \text { BP }\end{array}$ & $\begin{array}{l}\text { Upper } \\
\text { Palaeolithi } \\
\text { c }\end{array}$ & $\begin{array}{l}\text { Various sites } \\
\text { in France } \\
\text { and Spain }\end{array}$ & $\begin{array}{l}\text { Draws on } \\
\text { evidence of } \\
\text { children's } \\
\text { presence and } \\
\text { involvement in } \\
\text { making visual } \\
\text { imagery. }\end{array}$ & $\begin{array}{l}\text { Largely } \\
\text { theoretical } \\
\text { exploration of } \\
\text { how Upper } \\
\text { Paleolithic } \\
\text { children, who } \\
\text { grew up in } \\
\text { cultures with } \\
\text { strong visual } \\
\text { cultures, could } \\
\text { have used } \\
\text { metaphorical } \\
\text { thinking to } \\
\text { process visual } \\
\text { imagery. }\end{array}$ & $\begin{array}{l}\text { Nowell } \\
2015 b\end{array}$ \\
\hline $\begin{array}{l}\text { From 9,300 } \\
\text { BP } \\
\text { onwards }\end{array}$ & $\begin{array}{l}\text { Pre- } \\
\text { European } \\
\text { hunter- } \\
\text { gatherer } \\
\text { communiti } \\
\text { es }\end{array}$ & $\begin{array}{l}\text { Cueva de las } \\
\text { Manos } \\
\text { (Patagonia, } \\
\text { Argentina) }\end{array}$ & $\begin{array}{l}\text { Description of } \\
\text { rock art includes } \\
\text { hand stencils } \\
\text { attributed to } \\
\text { children, } \\
\text { adolescents and } \\
\text { both male and } \\
\text { female adults. }\end{array}$ & $\begin{array}{l}\text { Recording of } \\
\text { rock art, } \\
\text { including hand } \\
\text { stencils, and } \\
\text { associated } \\
\text { archaeological } \\
\text { excavations. }\end{array}$ & $\begin{array}{l}\text { Onetto } \\
\text { and } \\
\text { Podestá } \\
2011\end{array}$ \\
\hline N.D. & $\begin{array}{l}\text { Upper } \\
\text { Palaeolithi } \\
\text { C, possibly } \\
\text { Gravettian }\end{array}$ & $\begin{array}{l}\text { La Garma } \\
\text { (Spain) }\end{array}$ & $\begin{array}{l}\text { Analysis on } \\
\text { positioning and } \\
\text { context of hand } \\
\text { stencils } \\
\text { alongside } \\
\text { measurements. }\end{array}$ & $\begin{array}{l}\text { Possible hand } \\
\text { stencil } \\
\text { belonging to a } \\
\text { juvenile. }\end{array}$ & $\begin{array}{l}\text { Pettitt et } \\
\text { al. } 2014\end{array}$ \\
\hline $\begin{array}{l}\text { From } \\
14,400 \text { and } \\
13,000 \mathrm{BP} \\
(15,500-\end{array}$ & $\begin{array}{l}\text { Middle } \\
\text { Magdaleni } \\
\text { an }\end{array}$ & $\begin{array}{l}\text { Isturitz } \\
\text { (France), Las } \\
\text { Caldas } \\
\text { (Spain), La }\end{array}$ & $\begin{array}{l}\text { Identification of } \\
\text { examples of } \\
\text { lower skilled } \\
\text { engraving, such }\end{array}$ & $\begin{array}{l}\text { Microscopic } \\
\text { analysis of } \\
\text { mobiliary art to } \\
\text { identify skill }\end{array}$ & $\begin{array}{l}\text { Rivero } \\
2011\end{array}$ \\
\hline
\end{tabular}




\begin{tabular}{|c|c|c|c|c|c|}
\hline $\begin{array}{l}13,250 \mathrm{cal} \\
\mathrm{BC})\end{array}$ & & $\begin{array}{l}\text { Garma } \\
\text { (Spain) }\end{array}$ & $\begin{array}{l}\text { as difficulties } \\
\text { deepening a } \\
\text { single groove, } \\
\text { tool slippage, } \\
\text { accidents, } \\
\text { difficulty } \\
\text { performing } \\
\text { curved strokes. }\end{array}$ & $\begin{array}{l}\text { levels and } \\
\text { better } \\
\text { understand } \\
\text { transmission of } \\
\text { technical } \\
\text { knowledge. }\end{array}$ & \\
\hline $\begin{array}{l}\text { From } \\
14,400- \\
13,300 \text { cal } \\
\text { BP to } \\
17,550- \\
16,250 \text { cal } \\
\text { BP }\end{array}$ & $\begin{array}{l}\text { Middle } \\
\text { Magdaleni } \\
\text { an }\end{array}$ & $\begin{array}{l}\text { Isturitz } \\
\text { (France), Le } \\
\text { Mas d'Azil } \\
\text { (France), Las } \\
\text { Caldas } \\
\text { (Spain), La } \\
\text { Garma } \\
\text { (Spain) }\end{array}$ & $\begin{array}{l}\text { Three different } \\
\text { levels of skill } \\
\text { levels could be } \\
\text { distinguished for } \\
\text { the manufacture } \\
\text { of portable art: } \\
\text { inexperienced, } \\
\text { intermediate, } \\
\text { and } \\
\text { experienced. } \\
\text { There is also a } \\
\text { correlation b/w } \\
\text { these skill levels } \\
\text { and the raw } \\
\text { materials used. }\end{array}$ & $\begin{array}{l}\text { Microscopic } \\
\text { and statistical } \\
\text { analysis of } 280 \\
\text { pieces of } \\
\text { portable art } \\
\text { from French } \\
\text { and Spanish } \\
\text { Magdalenian } \\
\text { portable art. }\end{array}$ & $\begin{array}{l}\text { Rivero } \\
2016\end{array}$ \\
\hline $\begin{array}{l}\text { From } \\
14,400 \text { to } \\
13,300 \text { BP }\end{array}$ & $\begin{array}{l}\text { Middle } \\
\text { Magdaleni } \\
\text { an }\end{array}$ & $\begin{array}{l}\text { Isturitz } \\
\text { (France), Le } \\
\text { Mas d'Azil } \\
\text { (France), Las } \\
\text { Caldas } \\
\text { (Spain), La } \\
\text { Garma } \\
\text { (Spain) }\end{array}$ & $\begin{array}{l}\text { Identifies novice } \\
\text { and apprentice } \\
\text { level engravers, } \\
\text { alongside expert } \\
\text { engravers. }\end{array}$ & $\begin{array}{l}\text { microscopic } \\
\text { observation of } \\
\text { experimental } \\
\text { and } \\
\text { archeological } \\
\text { materials, the } \\
\text { latter } \\
\text { comprising } 289 \\
\text { pieces of } \\
\text { portable art } \\
\text { from the Middle } \\
\text { Magdalenian. }\end{array}$ & $\begin{array}{l}\text { Rivero } \\
2018\end{array}$ \\
\hline $\begin{array}{l}\text { Ca. } 12,340 \\
\text { BP }\end{array}$ & $\begin{array}{l}\text { Upper } \\
\text { Palaeolithi } \\
\text { c }\end{array}$ & $\begin{array}{l}\text { Bàsura Cave } \\
\text { (Italy) }\end{array}$ & $\begin{array}{l}\text { The cave was } \\
\text { explored by a } \\
\text { group of five } \\
\text { individuals of } \\
\text { mixed ages and } \\
\text { genders,includin } \\
\text { g children and } \\
\text { an adolescent. } \\
\text { The authors } \\
\text { document many } \\
\text { different types } \\
\text { of movement } \\
\text { and activities, } \\
\text { including use of } \\
\text { bundles for fire, } \\
\text { playing with }\end{array}$ & $\begin{array}{l}\text { Studied } 180 \\
\text { human } \\
\text { footprints and } \\
\text { traces in a } \\
\text { particular part } \\
\text { of the cave } \\
\text { using multiple } \\
\text { methods, } \\
\text { including laser } \\
\text { scans, } \\
\text { sedimentology, } \\
\text { archaeobotany, } \\
\text { geometric } \\
\text { morphometrics } \\
\text { and }\end{array}$ & $\begin{array}{l}\text { Romano } \\
\text { et al. } 2019\end{array}$ \\
\hline
\end{tabular}




\begin{tabular}{|c|c|c|c|c|c|}
\hline & & & $\begin{array}{l}\text { clay, kneeling } \\
\text { and crawling. }\end{array}$ & $\begin{array}{l}\text { photogrammetr } \\
\text { y. }\end{array}$ & \\
\hline $\begin{array}{l}\text { Ca. } 14,000 \\
\text { to } 13,000 \\
\text { BP }\end{array}$ & $\begin{array}{l}\text { Middle } \\
\text { Magdaleni } \\
\text { an }\end{array}$ & $\begin{array}{l}\text { Rouffignac } \\
\text { cave } \\
\text { (France) }\end{array}$ & $\begin{array}{l}\text { Some flutings } \\
\text { made by } \\
\text { children in } \\
\text { Chamber A1, } \\
\text { though it was } \\
\text { not possible to } \\
\text { reliably } \\
\text { distinguish } \\
\text { between } \\
\text { adolescents and } \\
\text { adults. In some } \\
\text { instances, } \\
\text { children must } \\
\text { have been } \\
\text { assisted to } \\
\text { reach the } \\
\text { ceilings upon } \\
\text { which they } \\
\text { fluted. }\end{array}$ & $\begin{array}{l}\text { experimentally } \\
\text { measured } \\
\text { finger widths of } \\
\text { a range of ages } \\
\text { of people, and } \\
\text { compared them } \\
\text { with } \\
\text { archaeological } \\
\text { flutings. }\end{array}$ & $\begin{array}{l}\text { Sharpe } \\
\text { and Van } \\
\text { Gelder } \\
2004\end{array}$ \\
\hline $\begin{array}{l}\text { Ca. } 14,000 \\
\text { to } 13,000 \\
\text { BP (but } \\
\text { authors } \\
\text { argue this } \\
\text { dating is } \\
\text { not certain) }\end{array}$ & $\begin{array}{l}\text { Possibly } \\
\text { Magdaleni } \\
\text { an }\end{array}$ & $\begin{array}{l}\text { Rouffignac } \\
\text { cave } \\
\text { (France) }\end{array}$ & $\begin{array}{l}\text { Finger flutings in } \\
\text { A1 appear to } \\
\text { have } \\
\text { been made by } \\
\text { children, some } \\
\text { potentially as } \\
\text { young as } 2 \\
\text { years old. }\end{array}$ & $\begin{array}{l}\text { Uses } \\
\text { experimental } \\
\text { finger fluting } \\
\text { measurements } \\
\text { made by a } \\
\text { sample of } \\
\text { people incl. } \\
\text { children, } \\
\text { recording age } \\
\text { and gender; } \\
\text { and compares } \\
\text { them with styles } \\
\text { and } \\
\text { measurements } \\
\text { in A1 } \\
\text { Rouffignac. }\end{array}$ & $\begin{array}{l}\text { Sharpe } \\
\text { and Van } \\
\text { Gelder } \\
2006\end{array}$ \\
\hline $\begin{array}{l}\text { Ca. } 30,000 \\
{ }^{14} \mathrm{C} \text { BP or } c . \\
34,000 \text { cal } \\
\text { BP }\end{array}$ & $\begin{array}{l}\text { Early to } \\
\text { middle } \\
\text { Upper } \\
\text { Palaeolithi } \\
\text { c }\end{array}$ & $\begin{array}{l}\text { Sunghir } \\
\text { (Russia) }\end{array}$ & $\begin{array}{l}\text { Grave } 2 \text { is a } \\
\text { double burial of } \\
\text { an adolescent } \\
\text { and juvenile. } \\
\text { Portable art } \\
\text { includes e.g. } \\
\text { ivory beads and } \\
\text { arm bands, } \\
\text { tooth pendants, } \\
\text { and open-work } \\
\text { ivory discs. Also } \\
\text { included were } \\
16 \text { ivory spears, } \\
\text { showing these }\end{array}$ & $\begin{array}{l}\text { Description of } \\
\text { grave goods in } \\
\text { a series of } \\
\text { burials at the } \\
\text { site, including } \\
\text { of children. }\end{array}$ & $\begin{array}{l}\text { Trinkaus } \\
\text { and } \\
\text { Buzhilova } \\
2018\end{array}$ \\
\hline
\end{tabular}




\begin{tabular}{|c|c|c|c|c|c|}
\hline & & & $\begin{array}{l}\text { children were } \\
\text { buried with both } \\
\text { objects related } \\
\text { to } \\
\text { ornamentation } \\
\text { as well as } \\
\text { utilitarian } \\
\text { objects. }\end{array}$ & & \\
\hline $\begin{array}{l}\text { Ca. } 20,000 \\
\text { BP }\end{array}$ & $\begin{array}{l}\text { Aboriginal } \\
\text { Australian }\end{array}$ & $\begin{array}{l}\text { Koonalda } \\
\text { Cave (South } \\
\text { Australia) }\end{array}$ & $\begin{array}{l}\text { Finger flutings, } \\
\text { identification of } \\
\text { children and } \\
\text { adults in the } \\
\text { cave as makers } \\
\text { of flutings. }\end{array}$ & $\begin{array}{l}\text { Morphometric } \\
\text { approach to } \\
\text { finger flutings } \\
\text { and identify } \\
\text { age, gender, } \\
\text { style, and } \\
\text { movement. }\end{array}$ & $\begin{array}{l}\text { Van } \\
\text { Gelder } \\
2015 a\end{array}$ \\
\hline Various & $\begin{array}{l}\text { Upper } \\
\text { Palaeolithi } \\
\text { c }\end{array}$ & $\begin{array}{l}\text { Rouffignac } \\
\text { cave } \\
\text { (France), } \\
\text { Gargas cave } \\
\text { (France), El } \\
\text { Castillo } \\
\text { (Spain), Las } \\
\text { Chimeneas } \\
\text { (Spain) }\end{array}$ & $\begin{array}{l}\text { Finger flutings, } \\
\text { showing } \\
\text { children fluters } \\
\text { present in the } \\
\text { caves, always in } \\
\text { the company of } \\
\text { older group } \\
\text { members. } \\
\text { Potential } \\
\text { contributors to } \\
\text { figurative art. }\end{array}$ & $\begin{array}{l}\text { Morphometric } \\
\text { approach to } \\
\text { finger flutings } \\
\text { and identify } \\
\text { age, gender, } \\
\text { style, and } \\
\text { movement. }\end{array}$ & $\begin{array}{l}\text { Van } \\
\text { Gelder } \\
2015 b\end{array}$ \\
\hline $\begin{array}{l}\text { Ca. } 14,000 \\
\text { to } 13,000 \\
\text { BP (but } \\
\text { authors } \\
\text { argue this } \\
\text { dating is } \\
\text { not certain) }\end{array}$ & $\begin{array}{l}\text { Upper } \\
\text { Palaeolithi } \\
\text { c }\end{array}$ & $\begin{array}{l}\text { Rouffignac } \\
\text { cave } \\
\text { (France) }\end{array}$ & $\begin{array}{l}\text { Finger flutings, } \\
\text { where at least } \\
\text { two of the fluters } \\
\text { were young } \\
\text { girls, ca. } 5 \text { years } \\
\text { old. }\end{array}$ & $\begin{array}{l}\text { Quantifyication } \\
\text { of finger flutings } \\
\text { to determine } \\
\text { sex and age. }\end{array}$ & $\begin{array}{l}\text { Van } \\
\text { Gelder } \\
\text { and } \\
\text { Sharpe } \\
2009\end{array}$ \\
\hline $\begin{array}{l}10,190 \pm \\
100 \mathrm{BP}\end{array}$ & $\begin{array}{l}\text { Magdaleni } \\
\text { an }\end{array}$ & $\begin{array}{l}\text { Abri de la } \\
\text { Madeleine } \\
\text { (France) }\end{array}$ & $\begin{array}{l}\text { Personal } \\
\text { ornaments } \\
\text { buried with the } \\
\text { child } \\
\text { demonstrate a } \\
\text { miniaturisation } \\
\text { of these to } \\
\text { match the small } \\
\text { body size of the } \\
\text { child. Signs of } \\
\text { use show that } \\
\text { children wore } \\
\text { these } \\
\text { ornaments } \\
\text { during life. }\end{array}$ & $\begin{array}{l}\text { Compared } \\
\text { grave goods } \\
\text { with reference } \\
\text { collections } \\
\text { (natural and } \\
\text { cultural) to } \\
\text { compare and } \\
\text { evaluate sizes } \\
\text { of ornaments in } \\
\text { the child burial. } \\
\text { Microscopic } \\
\text { study of } \\
\text { experimentally } \\
\text { produced and } \\
\text { archaeological } \\
\text { tooth pendants. }\end{array}$ & $\begin{array}{l}\text { Vanhaere } \\
\text { n and } \\
\text { d'Errico } \\
2001\end{array}$ \\
\hline
\end{tabular}




\begin{tabular}{|c|c|c|c|c|c|}
\hline $\begin{array}{l}\text { La } \\
\text { Madeleine: } \\
\text { 10,190 BP; } \\
\text { Grotte des } \\
\text { Enfants: } \\
\text { 11,130 BP }\end{array}$ & $\begin{array}{l}\text { Epipalaeoli } \\
\text { thic }\end{array}$ & $\begin{array}{l}\text { La Madeleine } \\
\text { (France), } \\
\text { Grotte des } \\
\text { Enfants } \\
\text { (Italy) }\end{array}$ & $\begin{array}{l}\text { Shells were } \\
\text { modified to } \\
\text { make them } \\
\text { smaller (La } \\
\text { Madeleine) or } \\
\text { selected for } \\
\text { their small size } \\
\text { (Grotte des } \\
\text { Enfants) to be } \\
\text { worn during life. }\end{array}$ & $\begin{array}{l}\text { Taphonomic } \\
\text { and } \\
\text { technological } \\
\text { study of the } \\
\text { personal } \\
\text { ornaments } \\
\text { associated with } \\
\text { two child burials } \\
\text { from different } \\
\text { sites, including } \\
\text { measuring } \\
\text { sizes of shells. }\end{array}$ & $\begin{array}{l}\text { Vanhaere } \\
\mathrm{n} \text { and } \\
\text { d'Errico } \\
2003\end{array}$ \\
\hline $\begin{array}{l}\text { Between } \\
\text { ca. } 19,000 \\
\text { and } 23,000 \\
\text { BP }\end{array}$ & $\begin{array}{l}\text { Aboriginal } \\
\text { peoples of } \\
\text { the Last } \\
\text { Glacial } \\
\text { Maximum }\end{array}$ & $\begin{array}{l}\text { Willandra } \\
\text { Lakes, New } \\
\text { South Wales } \\
\text { (Australia) }\end{array}$ & $\begin{array}{l}\text { Footprints } \\
\text { discovered in } \\
\text { hardpan, near a } \\
\text { shoreline } \\
\text { correspond to } \\
\text { children, } \\
\text { adolescents and } \\
\text { adults. }\end{array}$ & $\begin{array}{l}\text { Measurements } \\
\text { of footprints } \\
\text { and } \\
\text { comparisons } \\
\text { with present } \\
\text { day Aboriginal } \\
\text { Australian } \\
\text { anthropometric } \\
\text { data. }\end{array}$ & $\begin{array}{l}\text { Webb et } \\
\text { al. } 2006\end{array}$ \\
\hline
\end{tabular}

${ }^{*}$ As reported in the publication. N.D. means No Date was reported. NA means Not Applicable. Dates and cultural taxonomies will not always be repeated throughout the paper, please refer back to these tables.

\section{Acknowledgements}

We thank Julien Riel-Salvatore for his help with copies of publications pertaining to the Italian record, and Laurent Klaric for sending a copy of the 2018 edited volume on apprenticeship. We are very grateful to April Nowell for giving us copies of her book Growing up in the lce Age. Many thanks to Antiquity, Robert Losey and Emily Hull for permission to reproduce published images. We thank Todd Surrovell for the images of the Dukha playhouses, Olivia Rivero for sharing her images of novice engravings, Jessica Cooney Williams for her image of finger flutings, and Laurent Klaric for his image of carinated cores. We are grateful to two reviewers and the Associate Editor, whose suggestions for additional sources and clarifications have enriched the final result.

\section{Author contributions}

SLL, RR and NL conceived of the study. SLL, RR, and DF conducted the initial sorting. AM and SLL sorted and read the full texts, and conducted the analysis. AM wrote the paper with help from SLL. All authors critically read the text and contributed to its final editing. 


\section{References Cited}

Adovasio, J. M., Soffer, O., \& Page, J. (2016). The invisible sex: uncovering the true roles of women in prehistory. Routledge.

Anderson, L. (2018). Knowledge and know-how in Early Aurignacian lithic assemblages: the example of Tuto de Camalhot (Ariège, France). In L. Klaric (Ed.), The Prehistoric Apprentice: Investigating apprenticeship, know-how and expertise in prehistoric technologies / L'apprenti préhistorique. Appréhender l'apprentissage, les savoir-faire et l'expertise à travers les productions techniques des sociétés préhistoriques (Vol. 24, pp. 117-136). Brno: The Czech Academy of Sciences, Institute of Archaeology.

Ashton, N., Lewis, S. G., De Groote, I., Duffy, S. M., Bates, M., Bates, R., et al. (2014). Hominin Footprints from Early Pleistocene Deposits at Happisburgh, UK. PLoS ONE, 9(2), e88329. https://doi.org/10.1371/journal.pone.0088329

Assaf, E., Barkai, R., \& Gopher, A. (2016). Knowledge transmission and apprentice flintknappers in the Acheulo-Yabrudian: A case study from Qesem Cave, Israel. Quaternary International, 398, 70-85. https://doi.org/10.1016/j.quaint.2015.02.028

Athreya, S., \& Rogers Ackermann, R. (2018). Colonialism and narratives of human origins in Asia and Africa. In Interrogating human origins: decolonisation and the deep past (M. Porr \& J. Mathews, Eds.). Abingdon: Routledge. https://doi.org/10.31730/osf.io/jtkn2

Audouze, F., \& Cattin, M.-I. (2011). Flint wealth versus scarcity: consequences for Magdalenian apprenticeship. Lithic Technology, 36(2), 109-126.

Audouze, F., \& Janny, F. (2009). Can we hope to identify children's activities in Upper Palaeolithic settlements? In Proceedings of an International Conference University of Crete, Rethymno - June (Vol. 30, pp. 167-173). Presented at the International Conference University of Crete, Rethymno - June, Crete: Aegaeum Annales d'archéologie égéenne de l'Université de Liège et UT-PASP.

Audouze, F., \& Karlin, C. (2017). La chaîne opératoire a 70 ans : qu'en ont fait les préhistoriens français. Journal of Lithic Studies, 4(2), 5-73 https://doi.org/10.2218/jls.v4i2.2539

Azéma, M., \& Rivère, F. (2012). Animation in Palaeolithic art: a pre-echo of cinema. Antiquity, 86, 316-324.

Bamforth, D. B., \& Finlay, N. (2008). Introduction: archaeological approaches to lithic production skill and craft learning. Journal of Archaeological Method and Theory, 15(1), 127.

Bamforth, D., \& Hicks, K. (2008). Production skill and Paleoindian workgroup organization in the Medicine Creek Drainage, Southwestern Nebraska. Journal of Archaeological Method and Theory, 15(1, Skillful stones: Approaches to knowledge and practice in lithic technology), 132-153. https://doi.org/10.1007/sI0816-007-9045-I

Bardolph, D. (2014). A critical evaluation of recent gendered publishing trends in American Archaeology. American Antiquity, 79(3), 522-540.

Barnard, A. (2004). Hunter-Gatherers in history, archaeology and anthropology. New-York: Berg. 
Baxter, J. E. (2008). The Archaeology of Childhood. Annual Review of Anthropology, 37(1), 159-175. https://doi.org/10.1146/annurev.anthro.37.081407.085129

Bayón C, \& Politis G. (1996). Estado actual de las investigaciones en el Sitio Monte Hermoso 1 (Prov. de Buenos Aires). Arqueología. 1996;6:83-115.

Bayón, C., Manera, T., Politis, G.\& Aramayo, S. (2011). Following the Tracks of the First South Americans. Evo Edu Outreach 4, 205-217. https://doi.org/10.1007/s12052-011-03354

Bednarik, R. (1986). Parietal finger markings in Europe and Australia. Rock Art Research, 3(1), 30-61.

Bednarik, R. (2002). Paläolithische Felskunst in Deutschland? Archäologische Informationen, 25(1 \& 2), 107-117.

Bednarik, R. (2008). Children as Pleistocene artists. Rock Art Research, 25(2), 173-182.

Bégouën, R., Fritz, C., Tosello, G., Clottes, J., Pastoors, A., Faist, F., et al. (2009). Le sanctuaire secret des bisons: il ya 14000 ans, dans la caverne du Tuc d'Audoubert. Montesquieu-Avantès.

Bennett, M.R., Bustos, D., Odess, D., Urban, T.M., Lallensack, J.N., Budka, M., Santucci, V.L., Martinez, P., Wiseman, A.L.A., Reynolds, S.C. (2020). Walking in mud: Remarkable Pleistocene human trackways from White Sands National Park (New Mexico). Quaternary Science Reviews, 249, 106610.

Bird, D. W., \& Bliege Bird, R. (2002). Children on the reef: Slow learning or strategic foraging? Human Nature, 13, 269-297.

Bird, D. W., \& Bliege Bird, R. (2005). Mardu Children's Hunting Strategies in the Western Desert, Australia. In B. S. Hewlett \& M. E. Lamb (Eds.), Hunter-Gatherer Childhoods: Evolutionary, Developmental and Cultural Perspectives (pp. 129-147). New Brunswick: Transaction Publishers.

Bird-David, N. (2008). Feeding Nayaka Children and English Readers: A Bifocal Ethnography of Parental Feeding in "The Giving Environment." Anthropological Quarterly, 81(3), 523-550.

Bliege Bird, R., \& Bird, D. W. (2002). Constraints of knowing or constraints of growing? Fishing and collecting by the children of Mer. Human Nature, 13, 239-267.

Bobillo, F. M., \& Hocsman, S. 2015. (Revista del Museo de Antropología). Mucho más que solo aprovisionamiento lítico: Actividades en canteras y prácticas sociales en las fuentes de Pampa Oeste, Quebrada Seca y Punta de la Peña (Antofagasta de la Sierra, Catamarca). Revista del Museo de Antropología, 8(1), 23-44.

Bock, J., \& Johnson, S. E. (2004). Subsistence ecology and play among the Okavango Delta peoples of Botswana. Human Nature, 15(1), 63-81.

Bodu, P., Karlin, C., \& Ploux, S. (1990). Who's who? the Magdalenian flintknappers of Pincevent, France In Cziesla, E (ed.) The Big Puzzle: International symposium on refitting stone artefacts, Monrepos. Studies in Modern Archaeology, 1, 143-163. 
Bordes, J.-G., \& Bachellerie, F. (2018). Different skill levels and the structure of Early Upper Palaeolithic groups: the example of Canaule II (Châtelperronian) and Corbiac-Vignoble II (Early Aurignacian). In L. Klaric (Ed.), The Prehistoric Apprentice: Investigating apprenticeship, know-how and expertise in prehistoric technologies / L'apprenti préhistorique. Appréhender l'apprentissage, les savoir-faire et l'expertise à travers les productions techniques des sociétés préhistoriques (Vol. 24, pp. 147-163). The Czech Academy of Sciences, Institute of Archaeology.

Boyette, A. H., \& Hewlett, B. S. (2017). Autonomy, Equality and Teaching among Aka Foragers and Ngandu Farmers of the Congo Basin. Human Nature, 28, 289-322.

Boyette, A. H., \& Lew-Levy, S. (2021). Socialization, Autonomy, and Cooperation: Insights from Task Assignment Among the Egalitarian BaYaka. Ethos.

Boyette, Adam H. (2016). Play in Forager Societies. In J. L. Roopnarine (Ed.), The Cambridge Handbook of Play: Developmental and Disciplinary Persectives. Cambridge: Cambridge University Press.

Briggs, J. L. (1970). Never in Anger: Portrait of an Eskimo Family. Cambridge: Harvard University Press.

Briggs, J. L. (1978). The Origins of Nonviolence: Inuit Management of Aggression (Canadan Arctic). In A. Montagu (Ed.), Learning Non-Aggression: The Experience of Non-Literate Societies (pp. 54-93). New York: Oxford University Press.

Buchanan, B., (2006). An Analysis of Folsom Projectile Point Resharpening Using Quantitative Comparisons of Form and Allometry. Journal of Archaeological Science, 33, 185-199.

Callow, C. (2006). First steps towards an archaeology of children in Iceland. Archaeologia Islandica, 5, 55-96.

Castañeda, N. (2018). Apprenticeship in Early Neolithic Societies: The Transmission of Technological Knowledge at the Flint Mine of Casa Montero (Madrid, Spain), ca. 5300-5200 cal BC. Current Anthropology, 59(6), 716-740. https://doi.org/10.1086/700837

Cattin, M.-I. (2010). Comparing social organizations of Magdalenian hunter-gatherers. In E. Zubrow, F. Audouze, \& J. Enloe (Eds.), The Magdalenian Household Unravelling Domesticity (pp. 213-221). State University of New York Press.

Clark, J. E. (2003). Craftsmanship and craft specialization. In K. G. Hirth (Ed.), Mesoamerican Lithic Technology experimentation and interpretation (pp. 220-233).

Clottes, J. (2009). Sticking bones into cracks in the Upper Palaeolithic. In C. Renfrew \& I. Morley (Eds.), Becoming human Innovation in prehistoric material and spiritual culture (pp. 195-211). Cambridge, UK.

Cooney, J. (2012). Analysing the child burials of Upper Palaeolithic Europe. In K. Ruebens, I. Romanowska, \& R. Bynoe (Eds.), Unravelling the Palaeolithic Ten Years of Research at the Centre for the Archaeology of Human Origins CAHO, University of Southampton (pp. 97-108). Oxford.

Cooney, J. (2018). Portrait of a Palaeolithic family: art, ornamentation, and children's relationship with their community. In S. Crawford, D. M. Hadley, \& G. Shepherd (Eds.), The 
Oxford handbook of the archaeology of childhood (pp. 1-25). Oxford University Press. https://doi.org/10.1093/oxfordhb/9780199670697.013.17

Cooney Williams, J., \& Janik, L. (2018). Community Art: Communities of Practice, Situated Learning, Adults and Children as Creators of Cave Art in Upper Palaeolithic France and Northern Spain. Open Archaeology, 4(1), 217-238. https://doi.org/10.1515/opar-2018-0014

Cory, M. (2021). Playing with method: Testing one approach towards identifying the places of past children. Evolutionary Human Sciences, 3. https://doi.org/10.1017/ehs.2020.63

Crater Gershtein, K. M., Zaidner, Y., \& Yeshurun, R. (2020). A campsite on the open plain: Zooarchaeology of Unit III at the Middle Paleolithic site of Nesher Ramla, Israel. Quaternary International, S1040618220300276. https://doi.org/10.1016/j.quaint.2020.01.026

Crawford, S. (2009). The Archaeology of Play Things: Theorising a Toy Stage in the "Biography" of Objects. Childhood in the Past, 2(1), 55-70.

https://doi.org/10.1179/cip.2009.2.1.55

Crittenden, A. N. (2016). Children's foraging and play among the Hadza: The evolutionary significance of "work play." In C. L. Meehan \& A. N. Crittenden (Eds.), Childhood: Origins, evolution and implications (pp. 155-170). Albuquerque: University of New Mexico Press.

Crittenden, A. N., Conklin-Brittain, N. L., Zes, D. A., Schoeninger, M. J., \& Marlowe, F. W. (2013). Juvenile Foraging among the Hadza: Implications for Human Life History. Evolution and Human Behavior, 34(4), 299-304.

Cunnar, G. E. (2015). Discovering Latent Children in the Archaeological Record of the Great Basin. Childhood in the Past, 8(2), 133-148.

https://doi.org/10.1179/1758571615Z.00000000035

Darmark, K. (2010). Measuring skill in the production of bifacial pressure flaked points: a multivariate approach using the flip-test. Journal of Archaeological Science, 37(9), 23082315. https://doi.org/10.1016/j.jas.2010.04.004

Dawe, B. (1997). Tiny arrowheads: Toys in the toolkit. Plains Anthropologist, 42(161), 303318.

Debout, G. (2018). Adapting methods to skills: Interpreting the variability of Magdalenian backed bladelets at Pincevent and Verberie. In Klaric, L. (Ed.), The Prehistoric Apprentice: Investigating apprenticeship, know-how and expertise in prehistoric technologies / L'apprenti préhistorique. Appréhender l'apprentissage, les savoir-faire et l'expertise à travers les productions techniques des sociétés préhistoriques (Vol. 24, pp. 191-211). Brno:

The Czech Academy of Sciences, Institute of Archaeology.

Derevenski, J. S. (1996). Where are the children? Accessing children in the past.

Archaeological Review from Cambridge, 13(2), 7-20.

Derricourt, R. (2018). Unearthing childhood: Young lives in prehistory. Manchester: University of Manchester Press.

Dira, S. J., \& Hewlett, B. S. (2016). Learning to Spear Hunt Among Ethiopian Chabu Adolescent Hunter-Gatherers. In Social Learning and Innovation in Contemporary HunterGatherers (pp. 71-81). Tokyo: Springer Japan.

Donahue, R. E., \& Fischer, A. (2015). A Late Glacial family at Trollesgave, Denmark. Journal 
of Archaeological Science, 54(C), 313-324. https://doi.org/10.1016/j.jas.2014.12.018

Draper, P. (1976). Social and economic constraints on child life among the !Kung. In R. B. Lee \& I. DeVore (Eds.), Kalahari hunter-gatherers: Studies of the !Kung San and their neighbors (pp. 199-217). Cambridge and London: Harvard University Press.

Dugstad, S. A. (2010). Early child caught knapping A novice Early Mesolithic intknapper in south-western Norway. AmS Skrifter, 23, 65-74.

Eigeland, L. (2011). No man is an island: transmission of lithic knowledge in flint-scarce regions. Lithic Technology, 36(2), 127-140.

Elliott, B. (2009). Artefact biographies of the Star Carr barbed points [Master's Thesis]. University of York.

Ellis, C. (1994). Miniature Early Paleo-Indian Stone Artifacts from the Parkhill, Ontario Site. North American Archaeologist, 15(3), 253-267. https://doi.org/10.2190/V580-HT36-C5HAAWGW

Endicott, K. M. (2011). Cooperative autonomy: Social solidarity among the Batek of Malaysia. In T. Gibson \& K. Sillander (Eds.), Anarchic solidarity: Autonomy, equality, and fellowship in Southeast Asia (pp. 62-87). New Haven: Yale University Council on Southeast Asia Studies.

Eren, M. I., Bradley, B., \& Sampson, C. G. (2011). Middle Paleolithic skill level and the individual knapper: An experiment. American Antiquity, 76(2), 229-251.

Farbstein, R., \& Davies, W. (2017). Palaeolithic ceramic technology: The artistic origins and impacts of a technological innovation. Quaternary International, 441(Part B), 3-11.

https://doi.org/10.1016/j.quaint.2016.11.012

Ferguson, J. R. (2008). The when, where, and how of novices in craft production. Journal of Archaeological Method and Theory, 15(1), 51-67. https://doi.org/10.1007/sI0816-007-9047-z

Finlay, N. (1997). Kid knapping: the missing children in lithic analysis. In Invisible People and Processes writing gender and childhood into european archaeology (pp. 203-212). London.

Finlay, N. (2008). Blank concerns: issues of skill and consistency in the replication of Scottish Later Mesolithic blades. Journal of Archaeological Method and Theory, 15, 68-90. https://doi.org/10.1007/s10816-007-9048-y

Finlay, N. (2015). Kid-knapped Knowledge: Changing Perspectives on the Child in Lithic Studies. Childhood in the Past, 8(2), 104-112.

https://doi.org/10.1179/1758571615Z.00000000032

Finlayson, B., \& Warren, G. (2010). Changing natures: hunter-gatherers, first farmers and the modern world. London: Duckworth.

Fischer, A. (1990a). A late Palaeolithic "school" of flintknapping at Trollesgave, Denmark: results from refitting. Acta Archaeological, 60, 33-49.

Fischer, A. (1990b). On being a pupil of a flintknapper of 11,000 years ago. A preliminary analysis of settlement organization and flint technology based on conjoined flint artefacta from the Trollesgave site. In E. Cziesla, S. Eickhoff, N. Arts, \& D. Winter (Eds.), Proceedings of the International Symposium on refitting stone artefacts, Monrepos (pp. 447-484). 
Flegenheimer, N., Weitzel, C. \& Mazzia, N. (2015). Miniature points in an exceptional early South American context. World Archaeology, 47(1), 117-136.

Flegenheimer, N. \& Weitzel, C. (2017). Fishtail Points from the Pampas of South America: Their Variability and Life Histories. Journal of Anthropological Archaeology, 45, 142-156.

Formicola, V. (2007). From the Sunghir children to the Romito dwarf: aspects of the Upper Paleolithic funerary landscape. Current Anthropology, 48(3), 446-453.

Franklin, N. R., \& Habgood, P. J. (2009). Finger Markings and the Willandra Lakes Footprint Site, South-Eastern Australia. Rock Art Research, 26(2), 199-203.

French, J. C. (2019). The use of ethnographic data in Neanderthal archaeological research. Hunter Gatherer Research, 4(1), 25-49. https://doi.org/10.3828/hgr.2018.3

Frison, G. (1970a). The Kobold Site, 24BH406: A post-althithermal record of buffalo-jumping for northwestern Plains. Plains Anthropologist, 15(47), 1-35.

Frison, G. (1970b). The Glenrock Buffalo Jump, 48CO304: Late Prehistoric Period Buffalo Procurement and Butchering. Plains Anthropologist, 15(50), 1-48.

Fritz, C., Tosello, G., \& Conkey, M. W. (2016). Reflections on the Identities and Roles of the Artists in European Paleolithic Societies. Journal of Archaeological Method and Theory, 23, 1307-1332. https://doi.org/10.1007/s10816-015-9265-8

Gamble, C. (1999). The Palaeolithic societies of Europe. Cambridge: Cambridge University Press.

Garate, D., Rivero, O., Rios-Garaizar, J., Intxaurbe, I., \& Salazar, S. (2020). Modelled clay animals in Aitzbitarte IV Cave_A unique Palaeolithic rock art site in the Cantabrian Region. JASREP, 31, 102270. https://doi.org/10.1016/j.jasrep.2020.102270

Garcia, M. A., Duday, H., \& Courtaud, P. (1990). Les empreintes du Réseau Clastres.

Bulletin de la Societe prehistorique Ariege- Pyrenees prehistoire ariegeoise, XLV, 167-174.

Gardner, P. M. (1966). Symmetric Respect and Memorate Knowledge: The Structure and Ecology of Individualistic Culture. Southwestern Journal of Anthropology, 22 (4), 389-415.

Gardner, P. M. (1991). Foragers' pursuit of individual autonomy. Current Anthropology, 31, 543-572.

Gero, J. M. (1991). Genderlithics: Women's Roles in Stone Tool Production. In Gero, J. \& Conkey, M. (eds.) Engendering Archaeology: Women and Prehistory. Oxford: Basil Blackwell.

Gosselain, O.P., 2016. To hell with ethnoarchaeology! Archaeol. dialogues 23 (2), 215-228. https://doi.org/10.1017/S1380203816000234.

Gosso, Y. (2010). Play in Different Cultures. In P. K. Smith (Ed.), Children and Play (pp. 8098). Chichester: Blackwell Publishers Ltd.

Grimm, L. (2000). Apprentice flintknapping: relating material culture and social practice in the Upper Palaeolithic. In J. S. Derevenski (Ed.), Children and Material Culture (pp. 53-71).

London. 
Groënen, M. (1988). Les représentations de mains négatives dans les grottes de Gargas et de Tibiran (Hautes-Pyrénées): approche méthodologique. Bulletin de la Société royale belge d'Anthropogie et de Préhistoire, 99, 81-113.

Guarino, M.C. \& Sellet, F. (2019). An examination of the role of minature projectile points at the Lindenmeier Folsom Site, Colorado. PaleoAmerica, 5(2), 132-142.

Guthrie, R. D. (2005). The Nature of Paleolithic Art. University of Chicago Press.

Haas, R., Watson, J., Buonasera, T., Southon, J., Chen, J. C., Noe, S., et al. (2020). Female hunters of the early Americas. Science Advances, 6(45), eabd0310.

https://doi.org/10.1126/sciadv.abd0310

Hallam, S. J. (1971). Roof Markings in the 'Orchestra Shell' Cave, Wanneroo, near Perth, Western Australia. Mankind, 8, 90-103.

Hammond, G., \& Hammond, N. (1981). Child's play: a distorting factor in archaeological distribution. American Antiquity, 46(3), 634-636.

Hardenberg, M. (2010). In search of Thule children: Construction of playing houses as a means of socializing children. Geografisk Tidsskrift-Danish Journal of Geography, 110(2), 201-214. https://doi.org/10.1080/00167223.2010.10669507

Heizer, R. F., \& Johnson, I. (1952). A prehistoric sling from Lovelock Cave, Nevada. American Antiquity, 18(2), 139-147.

Hewlett, B. L. (2021). Social learning and innovation in adolescence: A comparative study of Aka and Chabu hunter-gatherers of Central and Eastern Africa. Human Nature.

Hewlett, B. S., Fouts, H. N., Boyette, A. H., \& Hewlett, B. L. (2011). Social learning among Congo Basin hunter-gatherers. Philosophical Transactions of the Royal Society B-Biological Sciences: Biological Sciences, 366(1567), 1168-1178.

https://doi.org/10.1098/rstb.2010.0373

Hewlett, B. S., \& Roulette, C. J. (2016). Teaching in Hunter-Gatherer Infancy. Royal Society Open Science, 3(15), 1-14.

Hildebrand, J. (2012). Children in Archaeological Lithic Analysis. Nebraska Anthropologist, $27,25-42$.

Högberg, A. (2008). Playing with Flint: Tracing a Child's Imitation of Adult Work in a Lithic Assemblage. Journal of Archaeological Method and Theory, 15(1), 112-131. https://doi.org/10.1007/s10816-007-9050-4

Högberg, A., \& Gärdenfors, P. (2015). Children, Teaching and the Evolution of Humankind. Childhood in the Past, 8(2), 113-121. https://doi.org/10.1179/1758571615Z.00000000033

Högberg, A., \& Larsson, L. (2011). Journal of Human Evolution, 61(2), 133-155. https://doi.org/10.1016/j.jhevol.2011.02.006

Hurcombe, L. (2007). Archaeological artefacts as material culture. London: Routledge.

Imamura, K. (2016). Hunting Play Among the San Children: Imitation, Learning, and Play. In H. Terashima \& B. S. Hewlett (Eds.), Social Learning and Innovation in Contemporary 
Hunter-Gatherers: Evolutionary and Ethnographic Perspectives (pp. 179-186). Tokyo: Springer Japan.

Imamura, K., \& Akiyama, H. (2016). How hunter-gatherers have learned to hunt: Transmission of hunting methods and techniques among the central Kalahari San. African Study Monographs, 52, 61-76.

Jacobi, R. (2004). The Late Upper Palaeolithic Lithic Collection from Gough's Cave, Cheddar, Somerset and Human Use of the cave. Proceedings of the Prehistoric Society, 70, 1-92. https://doi.org/10.1017/S0079497X00001110

Janny, F. (2010). Technologie Lithique à Verberie: Production Domestique et Apprentissage. In The Magdalenian Household (pp. 51-75).

Johansen, L., \& Stapert, D. (2008). Stone age kids and their stones. In Technology and archaeology proceedings of the SILA workshop (pp. 5-39).

Jordan, P. D. (2014). Technology as human social tradition: Cultural transmission among hunter-gatherers. Oakland: University of California Press.

Joyce, R. A. (2006). Where we all began: archaeologies of childhood in the Mesoamerican past. In T. Ardren \& S. Hutson (Eds.), The social experience of childhood in ancient Mesoamerica (pp. 283-301).

Joyce, R. A. (2012). Thinking about pottery production as community practice. In L. Cordell \& J. Habicht-Mauche (Eds.), Potters and Communities of Practice: Glaze paint and polychrome pottery in the American South- west, A.D. 1250-1700 (Vol. 1250, pp. 149-154). Tucson: University of Arizona Press.

Kamp, K. A. (2001). Where Have All the Children Gone?: The Archaeology of Childhood. Journal of Archaeological Method and Theory, 8(1), 1-34.

Kamp, K. A. (2015). Children and their Childhoods: Retrospectives and Prospectives. Childhood in the Past, 8(2), 161-169. https://doi.org/10.1179/1758571615Z.00000000037

Karlin, C. (1991). Connaissances et savoir-faire: comment analyser un processus technique en prehistoire. Treballs d'Arqueologia, 99-124.

Karlin, C., Ploux, S., Bodu, P., \& Pigeot, N. (1993). Some socio-economic aspects of the knapping process among groups of hunter-gatherers in the Paris Basin area. In Berthelet, Arlette, and Jean Chavaillon (eds)lemphThe use of tools by human and non-human primates. Oxford: Oxford University Press On Demand.

Kelly, T. (2013). Book Review: The better angels of our nature: A history of violence and humanity, by Steven Pinker. Anthropology Today, 29(4), 25-26.

Kenyon, D., \& Arnold, C. (1985). Toys as indicators of socialization in Thule culture. In Proceedings of the 16th Annual Chacmool Conference Status, Structure and Stratification Current Archaeological Reconstructions. The Archaeological Association of the University of Calgary. (pp. 347-353).

Klaric, L. (2018). Levels of flintknapping expertise and apprenticeship during the Late Upper Palaeolithic: several illustrative examples from the Early and Late Aurignacian and Middle Gravettian. In Klaric, L. (Ed.), The Prehistoric Apprentice: Investigating apprenticeship, know-how and expertise in prehistoric technologies (Vol. 24, pp. 49-116). Brno: The Czech 
Academy of Sciences, Institute of Archaeology.

Konner, M. J. (2005). Hunter-Gatherer Infancy and Childhood: The !Kung and Others. In B. S. Hewlett \& M. E. Lamb (Eds.), Hunter-Gatherer Childhoods: Evolutionary, Developmental and Cultural Perspectives (pp. 19-64). New Brunswick: Transaction Publishers.

Konner, M.J. (2016). Hunter-Gatherer Infancy and Childhood in the Context of Human Evolution. In C.L. Meehan \& A.N. Crittenden (Eds.). Childhood: Origins, Evolution, and Implications (pp. 123-145). Albuquerque: School for Advanced Research/University of New Mexico.

Koster, J., Mcelreath, R., Hill, K., Yu, D., Shepard, G., van Vliet, N., et al. (2020). The Life History Of Human Foraging: Cross-Cultural And Individual Variation. Science Advances, 6, eaax9070. https://doi.org/10.1101/574483

Kuhn, S. L., \& Stiner, M. C. (2001). The antiquity of hunter-gatherers. Hunter-gatherers: an interdisciplinary perspective, 99-142.

Kuhn, S. L., \& Stiner, M. C. (2006). What's a Mother to Do? Current Anthropology, 47(6), 953-981.

Lancy, D. F. (2016). Playing With Knives: The Socialization of Self-Initiated Learners. Child Development, 87(3), 654-665. https://doi.org/10.1111/cdev.12498

Lancy, D.F. (2017). Homo Faber Juvenalis: A Multidisciplinary Survey of Children as Tool Makers/Users. Childhood in the Past, 10(1), 72-90.

https://doi.org/10.1080/17585716.2017.1316010

Langlais, M. (2018). From the social composition of a campsite to Magdalenian cultural reproduction: Studying technical expertise at Verberie (Oise, France) to better understand sites in the Aquitaine Basin. In The Prehistoric Apprentice: Investigating apprenticeship, know-how and expertise in prehistoric technologies (pp. 251-268). Brno: The Czech Academy of Sciences, Institute of Archaeology.

Langley, M. C. (2018). Magdalenian children: projectile points, portable art and playthings. Oxford Journal of Archaeology, 37(1), 3-24. https://doi.org/10.1111/ojoa.12128

Langley, M. C. (2020). Space to play: Identifying children's sites in the Pleistocene archaeological record. Evolutionary Human Sciences, 2, e41.

https://doi.org/10.1017/ehs.2020.29

Langley, M. C., \& Litster, M. (2018). Is It Ritual? Or Is It Children? Distinguishing Consequences of Play from Ritual Actions in the Prehistoric Archaeological Record. Current Anthropology, 59(5), 616-643. https://doi.org/10.1086/699837

Lavi, N. (in press). The freedom to stop being free: Rethinking school education and personal autonomy among Nayaka children in South India. Hunter-Gatherer Research.

Lbova, L. (2021). The Siberian Paleolithic site of Mal'ta: A unique source for the study of childhood archaeology. Evolutionary Human Sciences, 3. https://doi.org/10.1017/ehs.2021.5

Lemke, A. K. (2018). Foraging in the past: archaeological studies of hunter-gatherer diversity. Colorado State University. 
Lewis, J. (2002). Forest Hunter-Gatherers and Their World: A Study of Mbendjele Yaka Pygmies of Congo-Brazzaville and Their Secular and Religious Activities and Representations (PhD Dissertation). London School of Economics and Political Science.

Lewis-Williams, J. D. (2009). Of people and pictures. In C. Renfrew \& I. Morley (Eds.), Becoming Human: Innovation in prehistoric material and spiritual culture (pp. 135-158). Cambridge: Cambridge University Press.

Lewis-Williams, J. D., Dowson, T. A., Bahn, P., Bandi, H. G., Bednarik, R., Clegg, J., et al. (1988). The Signs of All Times: Entopic Phenomena in Upper Palaeolithic Art [and Comments and Reply]. Current Anthropology, 29(2 (April)), 210-245.

Lew-Levy, S., Crittenden, A. N., Boyette, A. H., Mabulla, I. A., Hewlett, B. S., \& Lamb, M. E. (2019). Inter- and intra-cultural variation in learning-through-participation among Hadza and BaYaka forager children and adolescents from Tanzania and Congo. Journal of Psychology in Africa, 29(4), 309-318. https://doi.org/10.1080/14330237.2019.1647957

Lew-Levy, S., Kissler, S. M., Boyette, A. H., Crittenden, A. N., Mabulla, I. A., \& Hewlett, B. S. (2020). Who teaches children to forage? Exploring the primacy of child-to-child teaching among Hadza and BaYaka Hunter-Gatherers of Tanzania and Congo. Evolution and Human Behavior, 40(1), 12-22. https://doi.org/10.1016/j.evolhumbehav.2019.07.003

Lew-Levy, S., Lavi, N., Reckin, R., Cristóbal-Azkarate, J., \& Ellis-Davies, K. (2018). How Do Hunter-Gatherer Children Learn Social and Gender Norms? A Meta-Ethnographic Review. Cross-Cultural Research, 52(2), 213-255. https://doi.org/10.1177/1069397117723552

Lew-Levy, S., Milks, A., Lavi, N., Pope, S. M., \& Friesem, D. E. (2020). Where innovations flourish: an ethnographic and archaeological overview of hunter-gatherer learning contexts. Evolutionary Human Sciences, 2, 1-23. https://doi.org/10.1017/ehs.2020.35

Lew-Levy, S., Reckin, R., Lavi, N., Cristóbal-Azkarate, J., \& Ellis-Davies, K. (2017). How Do Hunter-Gatherer Children Learn Subsistence Skills?: A Meta-Ethnographic Review. Human Nature, 28(4), 367-394. https://doi.org/10.1007/s12110-017-9302-2

Lillehammer, G. (1989). A child is born. The child's world in an archaeological perspective. Norwegian Archaeological Review, 22(2), 89-105.

https://doi.org/10.1080/00293652.1989.9965496

Lillehammer, G. (2008). Something about children. In L. H. Dommasnes \& M. Wrigglesworth (Eds.), Children, identity and the past (pp. 96-112). Newcastle.

Lillehammer, G. (2010a). Archaeology of Children. Complutum, 21, 15-45.

Lillehammer, G. (2010b). Introduction to socialisation: Recent research on childhood and children in the past. AmS-Skrifter, 23, 9-19.

Lillehammer, G. (2010b). Archaeology of Children. Complutum, 21, 15-45.

Lombard, M. (2015). Hunting and hunting technologies as proxy for teaching and learning during the Stone Age of southern Africa. Cambridge Archaeological Journal, 25(4), 877-887.

Losey, R. J., \& Hull, E. (2019). Learning to use atlatls: equipment scaling and enskilment on the Oregon Coast. Antiquity, 93(372), 1569-1585. https://doi.org/10.15184/aqy.2019.172

Lye, T.-P. (1997). Knowledge, Forest, and Hunter-Gatherer Movement: The Batek of 
Pahang, Malaysia (PhD Dissertation). University of Hawaii.

Mackie, M. E., Surovell, T. A., \& O'Brien, M. (2015). Identifying Stone Alignments Created by Adults and Children: A Case Study from a Dukha Reindeer Herder Summer Camp, Khövsgöl Aimag, Mongolia. Sibirica, 14(2), 29-44. https://doi.org/10.3167/sib.2015.140202

Milks, A. (2020). A Review of Ethnographic Use of Wooden Spears and Implications for Pleistocene Hominin Hunting. Open Quaternary, 6: 12, pp. 1-20.

https://doi.org/10.5334/oq.85

Miller, H. (2012). Types of Learning in Apprenticeship. In W. Wendrich (Ed.), Archaeology and Apprenticeship body knowledge, identity, and communities of practice (pp. 224-239). https://www.jstor.org/stable/j.ctt180r3nf.13

Milne, S. B. (2005). Palaeo-Eskimo Novice Flintknapping in the Eastern Canadian Arctic. Journal of Field Archaeology, 30(3), 329-345. https://doi.org/10.1179/009346905791072224

Milner, N., Taylor, B., Conneller, C., \& Bayliss, A. (2018). Interpretative Narrative of the History of Occupation. In N. Milner, B. Taylor, \& C. Conneller (Eds.), Star Carr Volume 1: A Persistent Place in a Changing World. White Rose University Press.

Miotti, L., \& Terranova, E. (2015). A Hill Full of Points in Terra Incognita from Patagonia: Notes and Reflections for Discussing the Way and Tempo of Initial Peopling. PaleoAmerica, 1(2), 181-196. https://doi.org/10.1179/2055556315Z.00000000019

Mithen, S. (1988). Looking and learning: Upper Palaeolithic art and information gathering. World Archaeology, 19(3), 297-327.

Mithen, S. (1995). Palaeolithic Archaeology and the Evolution of Mind. Journal of Archaeological Research, 3(4), 305-332.

Moher, D., Liberati, A., Tetzlaff, J., Altman, D. G., \& PRISMA Group. (2009). Preferred reporting items for systematic reviews and meta-analyses: the PRISMA statement. Public Library of Science. https://doi.org/10.1371/journal.pmed.1000097

Musharbash, Y. (2011). Warungka: Becoming and Unbecoming a Warlpiri Person. In U. Eickelkamp (Ed.), Growing Up in Central Australia: New Anthropological Studies of Aboriginal Childhood and Adolescence (pp. 63-81). Oxford: BerghahnBooks.

Mussi, M. (1986). Italian Palaeolithic and Mesolithic burials. Human Evolution, 1(6), 545556.

Nami, H. G. (2007). Research in the Middle Negro River Basin (Uruguay) and the Paleoindian Occupation of the Southern Cone. Current Anthropology, 48(1), 164-174. https://doi.org/10.1086/510465

Nami, H. G. (2013). Archaelogy, Paleoindian Research and Lithic Technology in the Middle Negro River, Central Uruguay. https://doi.org/10.4236/ad.2013.11001

Naveh, D. (2016). Social and Epistemological Dimensions of Learning Among Nayaka I Hunter-Gatherers. In Hideaki Terashima \& B. S. Hewlett (Eds.), Social Learning and Innovation in Contemporary Hunter-Gatherers: Evolutionary and Ethnographic Perspectives (pp. 125-134). Tokyo: Springer Japan. 
Nishiaki, Y. (2013). "Gifting" as a means of cultural transmission: The archeological implications of bow-and- arrow technology in Papua New Guinea. In Y. Nishiaki \& K. Aoki (Eds.), Dynamics of learning in Neanderthals and modern humans, volume 1: Cultural perspectives (pp. 173-285). Tokyo: Springer Japan.

Nowell, A. (2015a). Learning to See and Seeing to Learn: Children, Communities of Practice and Pleistocene Visual Cultures. Cambridge Archaeological Journal, 25(4), 889-899. https://doi.org/10.1017/S0959774315000360

Nowell, A. (2015b). Children, Metaphorical Thinking and Upper Paleolithic Visual Cultures. Childhood in the Past, 8(2), 122-132. https://doi.org/10.1179/1758571615Z.00000000034

Nowell, A. (2016). Childhood, Play and the Evolution of Cultural Capacity in Neanderthals and Modern Humans. In M. N. Haidle, N. J. Conard, \& M. Bolus (Eds.), The Nature of Culture (pp. 87-97). Springer Netherlands. https://doi.org/10.1007/978-94-017-7426-0_9

Nowell, A. (2021). Growing up in the Ice Age: Fossil and archaeological evidence of the lived lives of Plio-Pleistocene children. Oxbow Books.

Nowell, A., \& French, J. C. (2020). Adolescence and innovation in the European Upper Palaeolithic. Evolutionary Human Sciences, 2, 23-24. https://doi.org/10.1017/ehs.2020.37

Nowell, A., \& White, M. (2010). Growing up in the Middle Pleistocene. In A. Nowell \& I. Davidson (Eds.), Stone tools and the evolution of human cognition (pp. 67-82). Boulder, Colorado: University Press of Colorado.

Onetto, M., \& Podestá, M. M. (2011). Cueva de las Manos: An Outstanding Example of a Rock Art Site in South America. Tanumshede, Adoranten. pp. 67-78

Ortega-Cordellat, M.-I. (2018). Exploring the interest of identifying different levels of technical competence for the prehistorian. The example of several Aurignacian, Gravettian, and Solutrean ope-air sites in the Bergerac region (Dordogne, France). In Klaric, L. (Ed.) The Prehistoric Apprentice: Investigating apprenticeship, know-how and expertise in prehistoric technologies / L'apprenti préhistorique. Appréhender l'apprentissage, les savoirfaire et l'expertise à travers les productions techniques des sociétés préhistoriques (Vol. 24, pp. 171-184). Brno: The Czech Academy of Sciences, Institute of Archaeology.

Park, R. W. (1998). Size counts: the miniature archaeology of childhood in Inuit societies. Antiquity, 72, 269-281.

Park, R. W. (2006). Growing Up North: Exploring the Archaeology of Childhood in the Thule and Dorset Cultures of Arctic Canada. Archaeological Papers of American Anthropological Association, 15, 53-64.

Park, R. W., \& Mousseau, P. M. (2003). How small is too small? Dorset culture "miniature" harpoon heads. Canadian Journal of Archaeology/ Journal Canadien d'archéologie, 27(2), 258-272.

Petersen, E. B., Jønsson, J. H., Juel, C., \& Kjær, A. (2015). Diversity of Mesolithic VKaredbæk. Acta archaeologica, 86(1), 7-13.

Pettitt, P. (2013). The Palaeolithic origins of human burial. Routledge. 
Pettitt, P., Castillejo, A. M., Arias, P., Peredo, R. O., \& Harrison, R. (2014). New views on old hands: The context of stencils in El Castillo and La Garma caves (Cantabria, Spain).

Antiquity, 88(339), 47-63. https://doi.org/10.1017/S0003598X00050213

Pigeot, N. (1990). Technical and social actors: flintknapping specialists and apprentices at Magdalenian Etoilles. Archaeological review from Cambridge, 9(1), 126-141.

Politis, G. (1998). Arqueología de al infacia: una perspectiva ethnoarqueológica/ Archaeology of childhood: an ethnoarchaeological perspective. Trabajos de prehistoria, 55(2), 5-19.

Politis, G. (1999). La actividad infantil en la producción del registro arqueológico de cazadores-recolectores. Revista do Museu de Arqueologia e Etnologia. Suplemento, supl.3, 263. https://doi.org/10.11606/issn.2594-5939.revmaesupl.1999.113473

Politis, G. (2005). Children's Activity in the Production of the Archaeological Record of Hunter-Gatherers: an ethnoarchaeological approach In lemphGlobal Archaeological Theory. Boston, MA: Springer.

Politis, G. (2007). Nukak: Ethnoarchaeology of an Amazonian People. London: publications of the institute of archaeology, University College London.

Politis, G., Costa Angrizani, R., Hernando, A., González Ruiba, A., Baserra Coelho, E. (2013). Quarenta e oito saídas: Etno-arqueologia das saídas diárias de forrageio dos Awá. In A. Hernando and E.M. Beserra Coelho (Eds.), Estudos sobre os Awá: Caçadores-Coletores em transição (pp. 155-186). São Luís: EDUFMA/IWGIA.

Rabinovich, R., Gaudzinski-Windheuser, S., \& Goren-Inbar, N. (2008). Systematic butchering of fallow deer (Dama) at the early middle Pleistocene Acheulian site of Gesher Benot Ya'aqov (Israel), 54(1), 134-149. https://doi.org/10.1016/j.jhevol.2007.07.007

Reckin, R., Lew-Levy, S., Lavi, N., \& Ellis-Davies, K. (2020). Mobility, autonomy, and learning: Could the transition from egalitarian to non-egalitarian social structures start with children? In L. Moreau (Ed.), Social inequality before farming? Multidisciplinary approaches to the study of social organisation in prehistoric and ethnographic huntergatherer-fisher societies (pp. 33-50). Cambridge: MacDonald Institute Monograph Series.

Rich, S. A., Watts, R., \& Momber, G. (2016). Mesolithic woodworking, experimental archaeology \& underwater heritage in Hampshire and the Isle of Wight (UK). Mesolithic Miscellany, 24(1), 3-12.

Riede, F., Johannsen, N. N., Högberg, A., Nowell, A., \& Lombard, M. (2018). The role of play objects and object play in human cognitive evolution and innovation. Evolutionary Anthropology, 27(1), 46-59. https://doi.org/10.1002/evan.21555

Riel-Salvatore, J., Clark, G. A., Larsson, L., Marshack, A., \& Mussi, M. (2001). Middle and Early Upper Paleolithic burials and the use of chronotypology in contemporary Paleolithic research. Commentaries. Authors' reply. Current anthropology, 42(4), 449-479.

Riel-Salvatore, J., \& Gravel-Miguel, C. (2013). Upper Palaeolithic mortuary practices in Eurasia. In The Oxford handbook of the archaeology of death and burial.

Rivero, O. (2011). La noción de aprendizaje en el arte mobiliar del Magdaleniense Medio cántabro-pirenaico: la contribución del análisis microscópico; La notion de l'apprentissage dans l'art mobilier du Magdalénien moyen cantabropyrénéen: la contribution des analyses 
microscopiques. Trabajos de prehistoria, 68(2), 275-295.

https://doi.org/10.3989/tp.2011.11070

Rivero, O. (2016). Master and apprentice: Evidence for learning in palaeolithic portable art. Journal of Archaeological Science, 75(C), 89-100. https://doi.org/10.1016/j.jas.2016.09.008

Rivero, O. (2018). Criteria for identifying artistic apprenticeship during the Middle Magdalenian. In Klaric, L. (Ed.), The Prehistoric Apprentice: Investigating apprenticeship, know-how and expertise in prehistoric technologies / L'apprenti préhistorique. Appréhender l'apprentissage, les savoir-faire et l'expertise à travers les productions techniques des sociétés préhistoriques (Vol. 24, pp. 275-288). Brno: The Czech Academy of Sciences, Institute of Archaeology.

Rivero, O., \& Garate, D. (2020). Motion and Gesture: Analysing Artistic Skills in Palaeolithic Art. Journal of Archaeological Method and Theory, 27(3), 561-584.

https://doi.org/10.1007/s10816-020-09476-5

Romano, M., Citton, P., Salvador, I., Arobba, D., Rellini, I., Firpo, M., et al. (2019). A multidisciplinary approach to a unique palaeolithic human ichnological record from Italy (Basura Cave). elifesciences.org, 1-31. https://doi.org/10.7554/eLife.45204.001

Rosendahl, G., Beinhauer, K.-W., Löscher, M., Kreipl, K., Walter, R., \& Rosendahl, W. (2006). Le plus vieil arc du monde? Une pièce intéressante en provenance de Mannheim, Allemagne. L'Anthropologie, 110(3), 371-382. https://doi.org/10.1016/j.anthro.2006.06.008

Rots, V. (2005). Wear traces and the interpretation of stone tools. Journal of Field Archaeology, 30(1), 61-73.

Roux, V., \& David, E. (2005). Planning abilities as a dynamic perceptual-motor skill: an actualist study of different levels of expertise involved in stone knapping. In V. Roux \& B. Bril (Eds.), Stone knapping The necessary conditions for a uniquely hominin behaviour (pp. 91-116). Cambridge.

Roveland, B. (2000). Footprints in the clay: Upper Palaeolithic children in ritual and secular contexts. In Children and Material Culture (pp. 29-38). Routledge.

Schwartzman, H. (2006). Materializing Children: Challenges for the Archaeology of Childhood. Archaeological Papers of American Anthropological Association, 15, 123-131.

Sharpe, K., \& Van Gelder, L. (2004). Children and Paleolithic "art": indications from Rouffignac Cave, France. International Newsletter on Rock Art, 38, 9-17.

Sharpe, K., \& Van Gelder, L. (2006). Evidence for cave marking by Palaeolithic children. Antiquity, 80(310), 937-947.

Shea, J. J. (2006). Child's play: Reflections on the invisibility of children in the paleolithic record. Evolutionary Anthropology, 15(6), 212-216. https://doi.org/10.1002/evan.20112

Sieveking, A. (1971). Palaeolithic decorated bone discs. The British Museum Quarterly, 35(1/4), 206-229.

Simonet, A. (2009). L'atelier de taille gravettien de Tercis (Landes). In Recherches sur les armatures de projectiles du Paléolithique supérieur au Néolithique (pp. 192-219).

Palethnologie. 
Simonet, A. (2012). Des apprentis gravettiens ont-ils confectionné des armatures lithiques à Tercis (Landes, France)? Paléo. Revue d'archéologie préhistorique, 23, 249-276.

Simonet, A. (2018). Differing skill levels and the chronological variability of the Gravettian in the Pyrenees: the examples of Tercis and Brassempouy (Landes, France). In Klaric, L. (Ed.), The Prehistoric Apprentice: Investigating apprenticeship, know-how and expertise in prehistoric technologies / L'apprenti préhistorique. Appréhender l'apprentissage, les savoirfaire et l'expertise à travers les productions techniques des sociétés préhistoriques (Vol. 24). Brno: The Czech Academy of Sciences, Institute of Archaeology. pp. 221-249

Snow, D. R. (2006). Sexual dimorphism in Upper Palaeolithic hand stencils. Antiquity, 80(308), 390-404. https://doi.org/10.1017/S0003598X00093704

Snow, D. (2013). Sexual Dimorphism in European Upper Paleolithic Cave Art. American Antiquity, 78(4), 746-761. https://doi.org/10.7183/0002-7316.78.4.746

Sonoda, K., Bonjkakova, D., \& Gallois, S. (2018). Cultural transmission of foundational schemas among Congo Basin hunter-gatherers. African Study Monographs: Supplementary Issue, 54, 155-169.

Sofaer, J. (Ed). (2000). Children and Material Culture. London: Routledge.

Sparacello, V. S., Rossi, S., Pettitt, P., of, C. R. J., \& 2018. (2018). New insights on Final Epigravettian funerary behaviour at Arene Candide Cave (Western Liguria, Italy) from osteological and spatial analysis of secondary bone Vdots. Journal of Archaeological Science: Reports, 96, 161-184. https://doi.org/10.4436/jass.89003

Spikins, P., Hitchens, G., Needham, A., \& Rutherford, H. (2014). The Cradle of Thought: Growth, Learning, Play and Attachment in Neanderthal Children. Oxford Journal of Archaeology, 33(3), 111-134.

Stapert, D. (2007). Neanderthal children and their flints. PalArchs Journal of Archaeology of Northwest Europe, 1(2), 16-40.

Sterelny, K. (2021). Veiled agency? Children, innovation and the archaeological record. Evolutionary Human Sciences, 3. https://doi.org/10.1017/ehs.2021.9

Sternke, F. (2011). Stuck between a rock and hard place: skill transmission and differential raw material use in Mesolithic Ireland. Lithic Technology, 36(2), 221-235.

Sternke, F., \& Sørensen, M. (2009). The identification of children's flintknapping products in Mesolithic Scandinavia. In Seventh International Conference on the Mesolithic in Europe, Belfast. (pp. 720-726).

Stiner, M C, Munro, N. D., \& Surovell, T. A. (2000). The tortoise and the hare. Current Anthropology, 41(1), 39-79.

Stiner, Mary C, Barkai, R., \& Gopher, A. (2009). Cooperative hunting and meat sharing 400200 kya at Qesem Cave, Israel. Proceedings of the National Academy of Sciences, 106(32), 13207-13212. https://doi.org/10.1073/pnas.0900564106

Takakura, J. (2013). Using Lithic Refitting to Investigate the Skill Learning Process: Lessons from Upper Paleolithic Assemblages at the Shirataki Sites in Hokkaido, Northern Japan. In Dynamics of Learning in Neanderthals and Modern Humans Volume 1 (pp. 151-171).

Tokyo: Springer Japan. https://doi.org/10.1007/978-4-431-54511-8_9 
Taylor, B., Conneller, C., Milner, Elliott, B., Little, A., Knight, B., \& Bamforth, M. (2018). Human Lifeways. In N. Milner, C. Conneller, \& B. Taylor (Eds.), Star Carr Volume 1: A Persistent Place in a Changing World (pp. 245-272). White Rose University Press.

Tehrani, J. J., \& Riede, F. (2008). Towards an archaeology of pedagogy: Learning, teaching and the generation of material culture traditions. World Archaeology, 40(3), 316-331.

https://doi.org/10.1080/00438240802261267

Temple, D. H. (2018). Exploring linear enamel hypoplasia as an embodied indicator product of childhood stress among Late/Final Jomon period foragers. In S. C. Agarwal \& P.

Beauchesne (Eds.), Children and childhood in the past (pp. 239-261).

University Press of Florida.

Terashima, H. (2016). Reflections on Hunter-Gatherer Social Learning and Innovation. In H. Terashima \& B. S. Hewlett (Eds.), Social Learning and Innovation in Contemporary HunterGatherers (pp. 311-318). Springer.

Thompson, T. K. (2003). Growing up Kaytetye: Stories. Alice Springs: Jukurrpa Books.

Trinkaus, E., \& Buzhilova, A. P. (2018). Diversity and differential disposal of the dead at Sunghir. Antiquity, 92(361), 7-21. https://doi.org/10.15184/aqy.2017.223

Tostevin, G. (2019) The Sharing of Lithic Technological Knowledge. In N. Lavi \& D. Friesem (Eds.), Towards a broader view of hunter-gatherer sharing. (pp. 195-208). Cambridge: McDonald Institute for Archaeological Research.

Tucker, B., \& Young, A. G. (2005). Growing up Mikea: Children's Time Allocation and Tuber Foraging in Southwestern Madagascar. In B. S. Hewlett \& M. E. Lamb (Eds.), HunterGatherer Childhoods: Evolutionary, Developmental and Cultural Perspectives (pp. 147171). New Brunswick: Transaction Publishers.

Van Gelder, L. (2015a). The Role of Children in the Creation of Finger Flutings in Koonalda Cave, South Australia. Childhood in the Past, 8(2), 149-160.

https://doi.org/10.1179/1758571615Z.00000000036

Van Gelder, L. (2015b). Counting the children: the role of children in the production of finger flutings in four Upper Palaeolithic caves. Oxford Journal of Archaeology, 34(2), 119-138.

Van Gelder, L., \& Sharpe, K. (2009). Women and Girls as Upper Palaeolithic Cave "Artists": Deciphering the Sexes of Finger Fluters in Rouffignac Cave. Oxford Journal of Archaeology, 28(4), 323-333.

Vanhaeren, M., \& d'Errico, F. (2001). La parure de l'enfant de la Madeleine (fouilles Peyrony). Un nouveau regard sur l'enfance au Paléolithique supérieur. Paléo, 13(13), 201240.

Vanhaeren, M., \& d'Errico, F. (2003). Childhood in the Epipaleolithic. What do personal ornaments associated to burials tell us. In Proceedings of the 6th International Conference on the Mesolithic in Europe.

Warren, G. (2021). Is There Such a Thing as Hunter-Gatherer Archaeology? Heritage, 4(2), 794-810. https://doi.org/10.3390/heritage4020044 
Webb, S., Cupper, M. L., \& Robins, R. (2006). Pleistocene human footprints from the Willandra Lakes, southeastern Australia. Journal of Human Evolution, 50(4), 405-413. https://doi.org/10.1016/j.jhevol.2005.10.002

Weedman, K. J. (2002). On the spur of the moment: effects of age and experience on hafted stone scraper morphology. American Antiquity, 67(4), 731-744.

Wengrow, D., \& Graeber, D. (2015). Farewell to the 'childhood of man': Ritual, seasonality, and the origins of inequality. Journal of the Royal Anthropological Institute, 21(3), 597-619.

Wild, M. (2020). Coping with risk through seasonal behavioral strategies: Technological analysis of selected late upper palaeolithic antler assemblages from northern Germany, southern Scandinavia and the Paris Basin. Untersuchungen und Materialien zur Steinzeit in Schleswig-Holstein und im Ostseeraum, Volume 12. Wachholtz.

Wilkins, J. (2020). Learner-driven innovation in the stone tool technology of early Homo sapiens. Evolutionary Human Sciences, 2, e40. https://doi.org/10.1017/ehs.2020.40

Willis, L., \& Boehm, A. (2015). Evaluating the role of skill level in fish butchery. Journal of Taphonomy, 13(1), 1-15. 